\title{
Frena equorum. Guarniciones de frenos de caballos en la antigüedad tardía hispánica
}

\author{
GiSELA RiPoll LÓPEZ ${ }^{\star}$ \\ MARTA DARDER LISSÓN**
}

en homenatge al

Professor Pere de Palol, en el seu 70 aniversari.

\section{INTRODUCCIÓN}

Dentro del horizonte, tanto histórico como cultural del Bajo Imperio, de los grandes latifundistas de Hispania y de las regiones mediterráneas, el caballo es una de las figuras más interesantes a estudiar ' . Este mundo de la antigüedad tardía muestra una clara continuidad rural y urbana que se aprecia esencialmente a través de la arqueología. Es esta continuidad la que nos obliga a analizar de un modo pluridisciplinar la problemática teórica y práctica del mundo de la equitación, a través, en este caso, de los instrumenta equorum, y más precisamente, de las camas de los frenos que forman parte de la cabezada del caballo y por tanto de su atalaje ${ }^{2}$.

* Departamento de Prehistoria, Historia Antigua y Arqueologia de la Universitat de Barceiona.

* La colaboración de la Dra. Marta Darder se refiere al catálogo y estudio de las camas con inscripción, asi cómo a la interpretación de las camas con decoración equina.

Agradecemos al Prof. Noël Duval el habernos invitado a pronunciar un seminario de doctorado sobre este tema, en el Instituto de Arte y Arqueologia-Universidad de la Sorbona-París IV, en febrero de 1988. Las discusiones nos ayudaron a reflexionar detenidamente sobre determinados problemas. A raiz de aquel seminario véase: Marta DARDER y Gisela RIPOLL, "Caballos en la antigüedad tardía hispánica", Revista de Arqueologia, 104, 1989, p. 40-51. Posteriormente profundizamos sobre las camas de frenos a raiz del estudio de una colección de materiales de la Bética y, aunque diferente, fue incluído en: Gisela RIPOLL, L'archéologie funéraire de Bétique d'aprés la collection visigothique du Römisch-Germanisches Zentralmuseus de Mayence, Thèse de Doctorat, Université de Sorbonne-Paris IV, 1993, Atelier National de Reproduction des Thèses sur Microfiche, Université de Lille III, 0741.15226/93, Lille, 1993 (cf. particularmente p. 28-70, 456-471 y fig. 12-28).

2 Todos los dibujos presentados en este trabajo, a excepción de aquellos donde se indica, han sido realizados por Natàlia Arranz, a la cual agradecemos su disponibilidad. También deseamos mos- 
El estudio del caballo en esta época suscita una serie de problemas que queremos traer a colación, aunque sólo sea someramente. Por una parte surgen aquellos relativos a la población agrícola y ganadera - los grandes possessores o potentiores y el material arqueológico hallado dentro de los latifundia- que han sido tratados por diferentes autores. Sin embargo, el único preocupado por el análisis de las estructuras arquitectónicas conjuntamente con el de los documentos, tales como las guarniciones de caballos, con el fin de reconstruir los diferentes aspectos sociales, ha sido P. de Palol ${ }^{3}$.

Por otra parte y dentro de esta misma problemática nos encontramos con la muy defendida tesis, por algunos, de la existencia de un limes en la zona del Duero, que obliga a ceñir los hallazgos exclusivamente a esta región. Sostener la teoría de este limes con lo que ello implica, es decir, presencia de limitanei y foederati, queda fuera de lugar, puesto que los mismos materiales -incluídos los frenos que estudiaremos más adelante- aparecen en otros lugares además de en la mencionada región ${ }^{4}$.

Las estructuras aquitectónicas de las grandes explotaciones agricolas y ganaderas, tal como deciamos, son frecuentemente estudiadas, conjuntamente con los materiales más destacados como son los mosaicos, las pinturas, la cerámica, etc., pero a menudo se olvida poner en relación los objetos metálicos de la vida cotidiana. Es precisamente dentro del campo del análisis de las artes del metal donde se ubica el estudio de las camas y de los filetes de los caballos. Como ya apuntó $P$. de Palol ${ }^{5}$, estas piezas que nos ocupan reflejan de forma evidente la mentalidad y el gusto de estos propietarios que tenian en sus dominios grandes cuadras destinadas a la cría caballar, puesto que los caballos contribuian no sólo a los placeres de la caza del possessor sino también a la participación en los juegos públicos, esencialmente circenses.

trar nuestra gratitud a Silvia Margenat, por todos sus consejos acerca de las cabezadas y guarniciones de frenos.

3 Entre toda su obra, nos interesa destacar: P. de PALOL, Castilla la Vieja entre el Imperio romano y el reino visigodo, Valladolid, 1970. El primer artículo sobre la guarnición de los caballos es: Id., "Algunas piezas de adorno de arnés de época tardorromana e hispano-visigoda", Archivo Español de Arqueologia, XXV, 1952, p. 297-319 (a partir de ahora lo citaremos como: PALOL 1952). El último: Id., “Bronzes d'epoca baix-romana i visigoda del Museu Episcopal de Vic", Studia Vicensia, 1, 1989, p. 35-59, 14 figs. (a partir de ahora PALOL 1989). Para la uilla de Pedrosa de la Vega, es preciso consultar dos de los volúmenes publicadas, esperando la publicación de la necrópolis: Id. y J. CoRTÉs, La villa romana de Pedrosa de la Vega (Palencia). Excavaciones de 1969 y 1970, "Acta Arqueológica Hispánica", 7, Madrid, 1974; y P. de PALOL, La villa romana de la Olmeda de Pedrosa de la Vega (Palencia). Guia de excavaciones, Palencia, 1981 (1984, $2^{\mathrm{a}}$ ed.).

4 Sobre esta antigua problemática hicimos ya referencia en: Gisela RIPOLL LOPEZ, "Caracteristicas generales del poblamiento y la arqueología funeraria visigoda de Hispania", Espacio, Tiempo y Forma, s. 1, 2, 1989, p. 389-418, cf. especialmente p. 400-401, nota 28 (con todo el aparato crítico).

5 Los articulos citados en la nota 3 se refieren a este tipo de problema. $P$. de Palol insiste sobre todo en el tema de los latifundia, los caballos y las tropas o agrupaciones militares. 
La vocación militar de estos caballos puede ser también un tema de reflexión a tratar con prudencia. La probable existencia de pequeñas tropas militares destinadas a la protección de los dominios y a la seguridad del propietario está todavia por demostrar ${ }^{6}$. No por ello creemos que la teoria del limes antes mencionada se pueda sostener. Si estas pequeñas tropas existieron, su función debió corresponder a la protección de los dominios agricolas de los grandes propietarios. Es plausible que estas tropas estuvieran constituidas por un pequeño número de hombres y que la de Theudis, con 2.000 , fuese una excepción. Si admitimos que los possessores tenian soldados a su servicio, entonces debemos aceptar todo lo que ello implica, es decir, la existencia de caballería y, por tanto, la instalación de cuadras, la manutención de los soldados, etc. Es posible que los soldados que componian las tropas militares privadas estuviesen al mismo tiempo al servicio de la explotación de las tierras. En efecto, tenian por regla general la condición de esclavos (servuli) o de campesinos libres (rusticani).

Si a ello sumamos el fenómeno de lo apreciados que eran los caballos hispánicos se comprende de forma más clara la existencia de cuadras destinadas a la cria y al adiestramiento de caballos, no sólo destinados a los ludi circenses sino también al ocio privado ${ }^{7}$. Estamos ante temas iconográficos, que como veremos más adelante, aparecen en las camas de los frenos. Precisamente son las escenas de caza y los caballos de parada las que ilustran el otium del que se disfrutaba en estas grandes propiedades. Son múltiples estas representaciones en los mosaicos hispánicos asi, por ejemplo, y sólo por citar alguno, el de Dulcitius de la uilla de El Ramalete (Tudela, Navarra) ${ }^{8}$ donde el propietario aparece montando su caballo enjaezado y capturando a un cuadrúpedo. Otra imagen que puede ser traida a colación es la ofrecida por la escena de caza del mosaico de Pedrosa de la Vega ${ }^{9}$. Tanto en uno como en otro, la cabezada del animal está fielmente reproducida. Lo mismo ocurre en el pavimento de Marianus y su caballo Pafius de Mérida ${ }^{10}$.

Abilio BARBero y Marcelo ViGIL, La formación del feudalismo en la Peninsula lbérica, Barcelona, 1978 (1986, 4a ed.), ver especialmente, p. 44-52.

Plinio, N.H., IV, 35. Ver también Ch. Daremberg y Edm. Sagl.o, Dictionnaire des antiquités grecques et romaines, s.v. equus, p. 797; L. ZIRKLE, "Animals impregned by the wind", /sis, 25 (1936), p. 95130; A. SAUVAGE, Etude des themes animaliers dans la poesie Latine. Les chevaux. Les oiseaux, Col. Latomus 143, Bruselas 1975, cf. p. 84-87. Claudio Claudiano, Laus Serenae, 50, 55, 70-75 y 110-115. Ver también: $P$. de PALOL, "Dos piezas de arnés con representaciones de caballos", Oretania, 5, 1960, p. 217-228, 7 figs., ct. p. 223, nota 8. Son de especial interés las cartas de Simmaco, entre otras: Symmachus, Epistulae, LVIII, LIX y LX; ver los comentarios al respecto en J. ARCE, "Los caballos de Simmaco", Faventia, 4, 1982, p. 35-44; J.M. BLÁzQUEZ, "La caballería en Hispania durante el Bajo Imperio", Hestiasis (Studi Tardoantichi), II, Messina, 1989, p. 45-76.

8 B. Taracena, L. Vazquez de Parga y Ma A. Mezouiriz, Excavaciones en Navarra. 1I. (1947-1951), Pamplona, 1956, p. 3-40, pl. I-xxi, esp. pl. X-XII.

9 PALOL, La villa romana de la Olmeda... Guía de las excavaciones, op. cit., con buenas fotografias de las escenas de caza.

10 José María Álvarez Martinez, Mosaicos romanos de Mérida. Nuevos hallazgos, "Monografias Emeritenses", 4, 1990, n. 14, p. 79-93. 
Donde la cabezada aparece con mayor definición es en el caballo de la villa de Dueñas con la inscripción de Amoris (fig. 1). El freno presenta una cama en forma de ocho deformado y un filete de palillos (en literatura arqueológica es frecuente la utilización errónea de filete doble troncocónico). El caballo de la villa de Dueñas presenta una particularidad especial y es que además de la cabezada del filete lleva una segunda cabezada de presentación. Ésta tiene una doble funcionalidad: por un lado, ornato, por otro llevar al caballo del diestro, o ligarlo en momentos de reposo. De las dos partes de la cabezada de presentación se distinguen claramente la muserola, el montante de la muserola y el ronzal, además del ahogadero. Éste último está sujeto a la frontalera por medio de una roseta o bien una falera. Del ahogadero cuelga un latiguillo con una falera en forma de círculo partido. Cabe señalar también la disposición de un collar o gargantilla muy ornamentada que, por otra parte, suele ser frecuente en las escenas con caballos de parada de la cual pende una campanilla ${ }^{11}$. Estamos por tanto ante una de las pocas representaciones iconográficas de los objetos que nos interesan y su funcionalidad queda fuera de dudas. Por otra parte, este mosaico de Dueñas, junto con las pocas referencias estratigráficas que se poseen para los hallazgos, nos permite acercarnos a una cronología, sino absoluta, si relativa.

Los temas iconográficos de los mosaicos se repiten en las camas de los frenos. Mención especial merecen las imágenes de animales afrontados y en posición heráldica, habituales en la iconografía a todo lo largo de la antigüedad y que deben ser puestos en relación con las representaciones caracteristicas de los mosaicos con el tema de los caballos vencedores afrontados a una palma de la victoria o a un modius o cilindro de premio ${ }^{12}$. La repre-

"Amoris, es para P. de Palol, el nombre del caballo: P. de PALOL, "Una tumba romana de Toledo y los frenos de caballo hispanorromanos del Bajo Imperio", Pyrenae, VIII, 1972, p. 133-146, cf. particularmente p. 145, nota 25 (a partir de ahora abreviado PALOL 1972). No creemos que sea factible, pues Amoris es el genitivo de Amor (como Erae de Hera en el cuello del caballo Narcissus de Mérida), por tanto no se refiere al caballo. Véase también la interpretación de la faleta en forma de circulo partido como una $C$ de $c$ (aballus) por Isabel RoDÀ, "Iconografía y epigrafía en dos mosaicos hispánicos: las villae de Tossa y Dueñas", Actas del VI Coloquio internacional sobre el mosaico antiguo, PalenciaMérida 1990, Guadalajara, 1994, p. 35-42. Algunas sugerencias sobre inscripciones en el cuello de los caballos en: M. DARDER LISSÓN, "El mosaic circenc de Barcino. Implicacions iconogràfiques a partir de les aportacions semàntiques", Butlleti de la Reial Academia Catalana de Belles Arts de Sant Jordi, VIIVIII, 1993-1994, p. 251-281. Aprovechamos para dejar bien claro que Amoris no es el nombre del cabaIlo, hecho que nunca hemos afirmado a pesar de que en el pie de la figura de la página 49 del artículo DARDER y RIPOLL, "Caballos en la antigüedad tardía...", op. cit., se anotase "representación de un caballo y su nombre"; esto responde a un error del editor. Acerca de la campanilla que aparece colgando de la gargantilla del caballo, existen numerosos documentos arqueológicos, particularmente en el Norte de África (cf. Volubilis), véanse las recogidas en: Ch. Boube PICCOT, Les bronzes antiques du Maroc. III. Les chars et l'attelage, Etudes et travaux d'Archéologie Marocaine, Vlll. Rabat, 1980, especialmente p. 182. 186, lám. 58, fig. 28.

12 M.R. LUCAS PELLICER, «La influencia africana en la iconografia equina de la vilia de Aguilafuente (Segovia)", Homenaje al Profesor Gratiniano Nieto, Cuadernos de Prehistoria y Arqueologia, 13-14, Madrid, 1986-1987, vol. II, p. 219-235, 6 figs., 2 lám. Sólo citamos algunos ejemplos de mosaicos africa- 


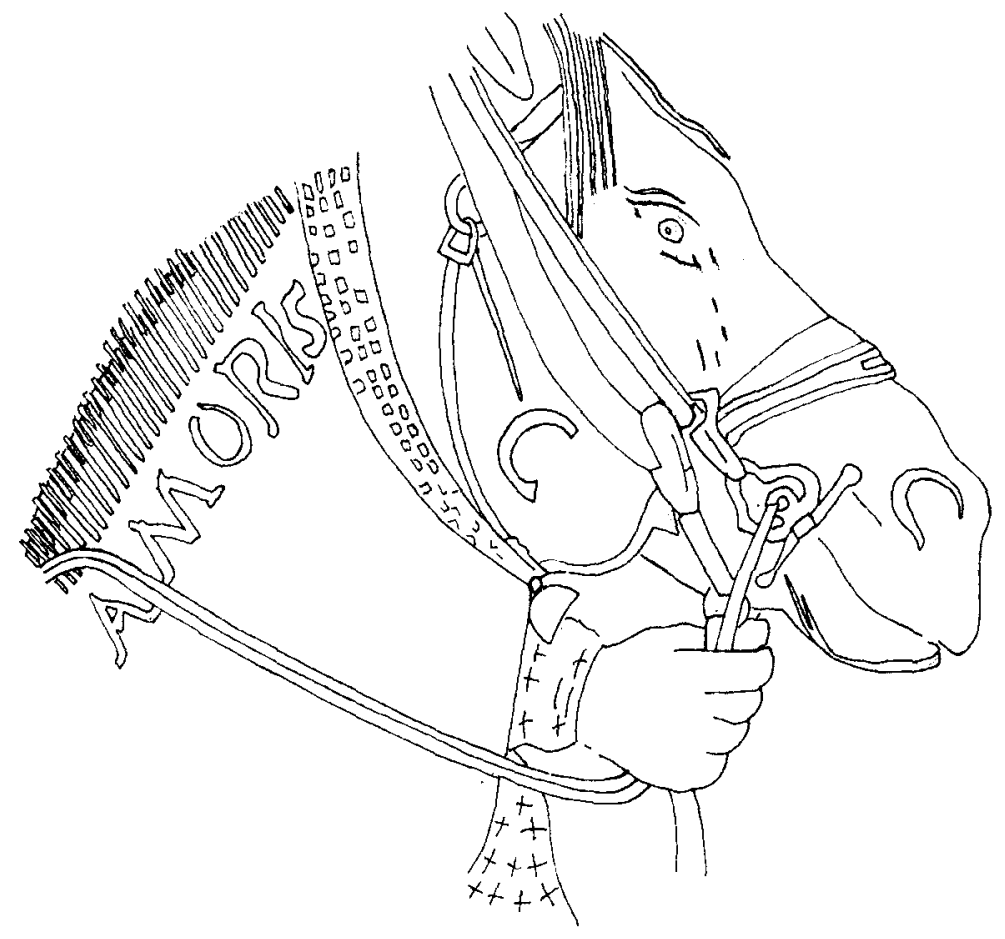

Fig. 1. Dibujo de la doble cabezada del mosaico del caballo de Dueñas (Palencia).

sentación de un único caballo, a veces incluso con su nombre, recuerda la buena reputación de los équidos hispánicos tal como hemos ya avanzado. Lo mismo ocurre en lo que a escenas de uenationes se refiere y que hemos mencionado anteriormente.

\section{TÉCNICAS}

Seguidamente pasaremos a la definición de las formas de enjaezamiento: vocabulario, tipologia y descripción, aún siendo conscientes de la dificultad de 
interpretación que éstos presentan. Estas páginas demuestran que estos objetos son partes de un freno de caballo y que otras posibles interpretaciones no pueden aceptarse. La primera argumentación a la que hemos aludido de la cabezada del caballo de Dueñas se ve apoyada por una referencia textual de Isidoro de Sevilla en su De instrumentis equorum: Frena dicta quod equos fremere cogant ${ }^{13}$. Creemos que, es precisamente a este tipo de frenos - los frena-, a los que se refiere Isidoro y no a las phalerae que son sólo ornamenta equorum.

Todo parece indicar que a lo largo de los siglos IV al VI d.C., estos objetos se fabricaron en talleres locales hispánicos. El conocimiento actual es restringido —cerca de 80 ejemplares-y todo aboga por considerar este fenómeno como una producción que responde a una moda local. Las camas halladas en la Mauritania Tingitana ${ }^{14}$, presentan unas conexiones morfológicas y ornamentales evidentes con las procedentes de la geografía peninsular, pero no responden a los mismos artesanos, salvando raras excepciones, sobre las que volveremos cuando abordemos las diferentes interpretaciones, puesto que podria tratarse de hallazgos debidos al comercio. La dispersión geográfica, particularmente en Hispania (fig. 30), es grande y cada vez cubre más zonas donde se desconocian este tipo de hallazgos. Sobre estos temas se han ocupado ya algunos investigadores ${ }^{15}$, aunque incidiremos sobre ello, dado que el número ha aumentado considerablemente.

Los frenos y bocados utilizados a lo largo de la antigüedad son muchos, aunque sus modalidades y funcionamiento no variaron en gran manera, debido a su sencillez, pues sostenian sólo un par de habenae o retinaculae (riendas) y los montantes. El sistema deviene complejo cuando se utilizan filete y bocado juntos, puesto que se sujetan a dos pares de riendas. Cabe recordar que incluso hoy en día esta embocadura doble es la menos utilizada.

Existen muy variados tipos de frenos ${ }^{16}$, sin embargo el filete articulado señala un progreso técnico notable con respecto a los filetes rígidos y a los bocados. Éste, libera la boca del caballo sin menoscabar su conducción y es el más amplia-

13 Isidorus Hispalensis, Etymologiae, XX, 16.1.

14 BOUBE PICCOT, Les bronzes antiques du Maroc..., op. cit. Esta obra es de suma importancia para el conocimiento del mundo caballar en la Mauritania Tingitana, pues se reúnen un gran número de hallazgos correspondientes a las variadas guarniciones de los équidos. Los paralelismos que se pueden establecer son amplios, por la morfologia de las piezas, éstas fueron producidas en talleres africanos y no en hispánicos, aunque sobre el comercio entre ambas zonas, volveremos más adelante.

is L. CABALlERO, La necrópolis tardorromana de Fuentespreadas (Zamora). Un asentamiento en el valle del Duero, "E.A.E.", 80, 1974 (abreviado a partir de ahora con CABALLERO 1974). El trabajo elaborado por el Dr. Caballero es particularmente interesante para el conocimiento de las camas filiformes y de decoraciones con arcos de herradura o escutiformes, temas sobre los que no nos extenderemos puesto que en dicha obra están ampliamente tratados.

16 Dos buenas introducciones al mundo caballar en general, y también relativas a esta problemática son: P. VIGNERON, Le cheval dans I'antiquité greco-romaine (Des guerres médiques aux grandes invasions). Contribution à /'histoire des techniques, Nancy, 1968, 2 vols.; y Marcus JunkELmann, Die Reiter Roms, vol. I, Maguncia, 1990 y vol. II, Maguncia, 1991. 
mente utilizado incluso en nuestros dias. El filete articulado, fabricado en materiales muy ligeros, no daña la boca del animal ya que ejerce su efecto sobre la comisura de los labios, al contrario de los bocados que actúan sobre las barras.

El freno de filete articulado (compuesto por dos camas, dos cañones y dos anillas) (fig. 2) fue probablemente utilizado por caballos pertenecientes a la caballería ligera y a veces por caballos de carreras, pero con toda seguridad lo fue por los caballos de parada. Este tipo de freno contrasta con los bocados más tardios y corrientes en el mundo visigodo e hispano-visigodo de los siglos $\mathrm{VI}$ y $\mathrm{VII}{ }^{17}$, que suelen ser bocados con desveno y camas largas y de gran volumen, pero presentan a veces una embocadura articulada en vez de una rígida. No obstante, los paralelismos iconográficos entre ambos no dejan de tener estrechas relaciones ${ }^{18}$. Tan sólo cinco hallazgos permiten afirmar que las camas con enganche de montante que estudiamos son frena, pues han sido encontrados en su estado original, aunque el filete suele estar ligeramente deteriorado debido a su fabricación en hierro. Se trata de los hallazgos de Vega Baja (Toledo), el localizado en la habitación 62 de Clunia (Burgos), los procedentes de la excavación de la necrópolis de Fuentespreadas (Zamora) y por último el de la Colección Fontaneda descubierto en algún lugar de la provincia de Palencia ${ }^{19}$.

El freno procedente de la Vega Baja ( $n^{\circ} 4-5$, fig. 3) fue hallado en el interior de una tumba asociado a varios instrumentos de cirugía y a una moneda de Marco Aurelio fechada entre los años 161-180 d.C., pertenecientes probablemente a un médico ${ }^{20}$. El freno se compone de dos camas recortadas en planchas de bronce de tipo peltiforme con un enganche en la parte superior destinado a sujetar el montante y un orificio en la zona central para el paso del filete y su sujeción por medio de una anilla a la rienda. El filete, propiamente dicho, se articula en la parte central gracias a dos anillas entrelazadas. Cada cañon del filete es de unos $9 \mathrm{~cm}$. de longitud, es decir un total de 18 o $20 \mathrm{~cm}$., dimensión que corresponde bien a la quijada de un caballo. Este freno de la Vega Baja, cuyos elementos peltiformes no se repetirán de nuevo en ningún ejemplar, debe ser fechado como mínimo hacia finales del siglo II d.C. - si no es posterior-y se trata por tanto del ejemplar más antiguo dentro de la serie que presentamos.

17 P. de PALOL, "Bronces con decoración damasquinada en época visigoda", $V$ Congreso Nacional de Arqueología, Zaragoza, 1957, Zaragoza, 1959, p. 292-305, lám. VIII. Véase también la entrada de catálogo realizada por Katherine REYNOLDS BROWN, aHorse bit", The art of medieval Spain, a.d. 500-1200, The Metropolitan Museum of Art, Nueva York, 1993, p. 68-69.

${ }_{18}$ Véase particularmente la decoración esquematizada del bocado de este tipo de objetos, cf. nota 17.

19 Para Toledo: Palol 1972, p. 136-142 et 145, fig. 8, pl IV, 1 et 2. Para Clunia: Palol 1989, p. 48 49, fig. 11. Para Fuentespreadas: CABALLERO 1974, p. 74-76, fig. 18. El freno de la Colección Fontaneda en: P. de PALOL, "Bronces romanos de la provincia de Palencia", BSAA, XXXIII, 1967, p. 236-240, pl. IV$\checkmark$ (a partir de ahora: PALOL 1967).

20 PALOL 1972, p. 145, fig. IV. 2. Se reproduce el conjunto pero no la moneda. 


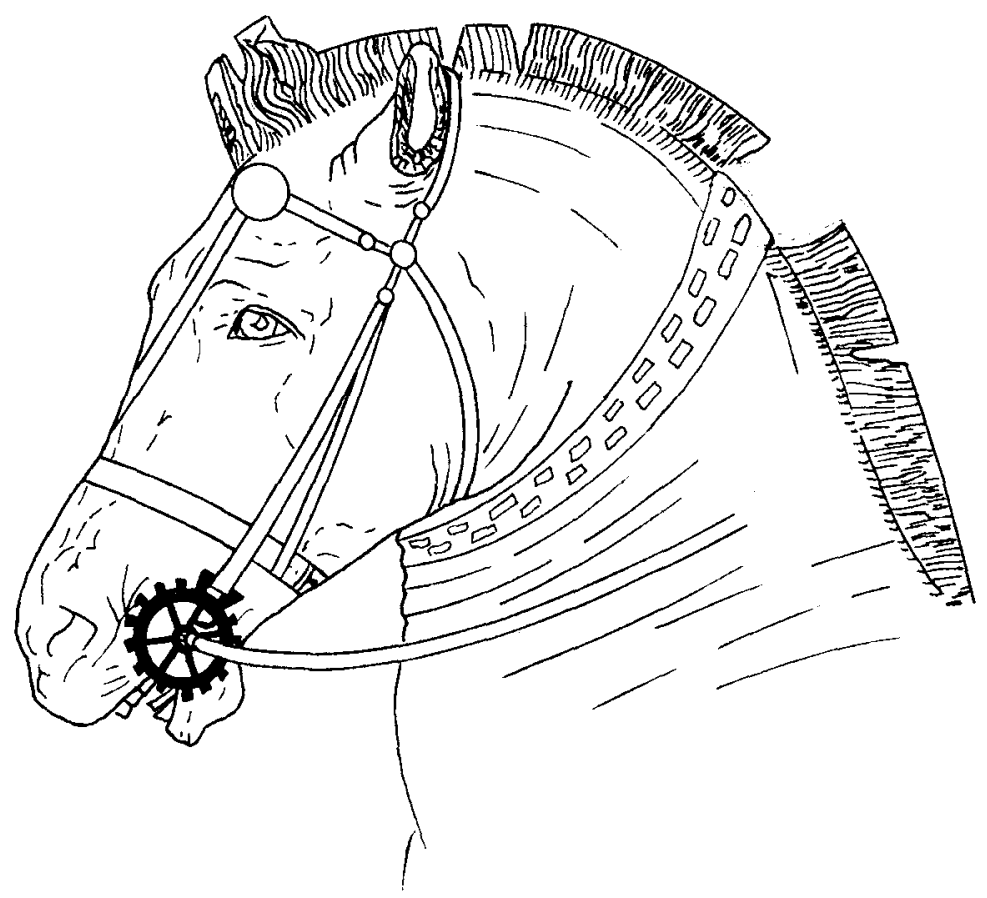

Fig. 2. Cabezada de un caballo con los diferentes elementos de guarnición.

Otro de los frenos al que nos referíamos es el hallado en la habitación 62 de la casa $n^{\circ} 1$ de Clunia, en las excavaciones llevadas a cabo por Blas Taracena en 1933 en ese sector ${ }^{21}$. Las camas circulares son de tipo rigido $\left(n^{\circ} 6-7\right.$, fig. 7$)$, es decir no han sido caladas y el enganche de montante es de forma triangular con perforación rectangular. En la parte central, el filete se articula gracias a dos anillas. De los extremos del filete penden a la vez dos anillos portarriendas.

El tercer ejemplo de freno $\left(n^{\circ} 27\right.$ y 28 , fig. 3) es un hallazgo descontextualizado procedente de la provincia de Palencia ${ }^{22}$. Se trata también de un filete articulado centralmente por medio de dos anillas, en cuyos extremos penden sendos pasos de rienda. El filete atraviesa la cama gracias a un orificio central circular muy desgastado. En el caso de esta pieza de la provincia de Palencia, las camas son circulares, una de ellas con una decoración geométrica central y su correspondiente enganche de montante. 

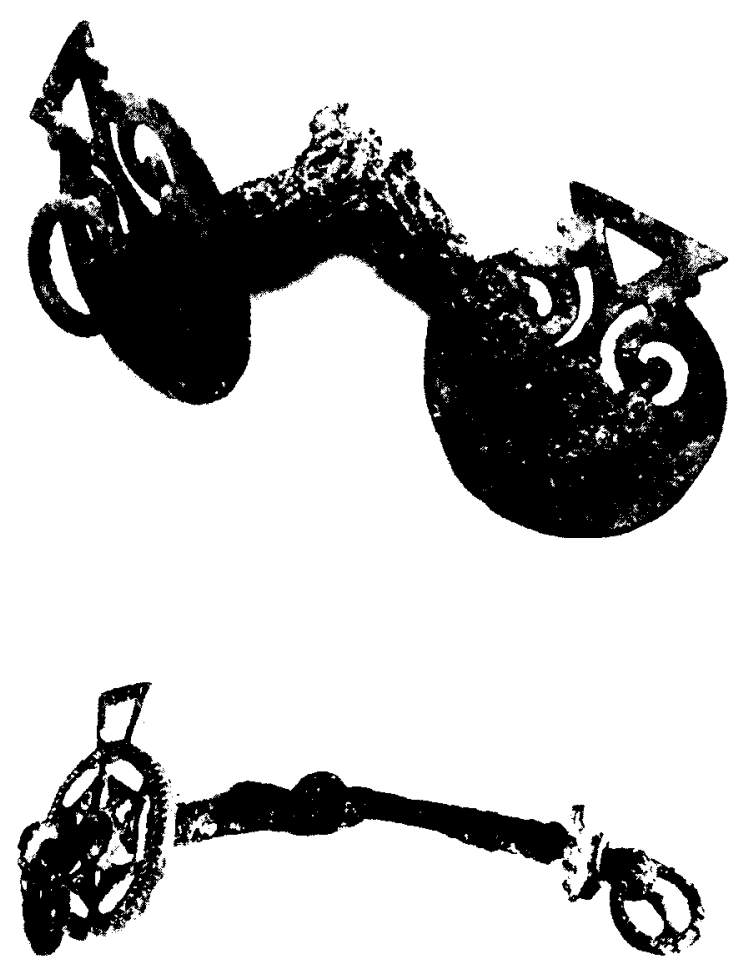

Fig. 3. Frenos procedentes de Vega Baja (Toledo) y de la provincia de Palencia (Colección Fontaneda) (según P. de Palol, 1972).

Mención especial merecen los dos hallazgos procedentes de Fuentespreadas $\left(n^{\circ} 8-9\right.$ y $10-11$, fig. 4) ${ }^{23}$. Se trata de dos frenos hallados en, prácticamente, la única sepultura, la $n^{\circ} 1$, conocida de la necrópolis. Los dos frenos aparecieron completos: los dos cañones articulados por medio de anillas, las dos camas y los anillos

23 Caballero 1974 , p. 23. 
portarriendas. Las camas de uno de ellos ( $\left.n^{\circ} 8-9\right)$ son simples, en cambio las del otro ( $\left.n^{\circ} 10-11\right)$ presentan un trabajo más elaborado con decoración somera (fig. 4). Los frenos se hallaron asociados a un gran número de piezas correspondientes a guarniciones de dos caballos, además de objetos de adorno personal, servicios de mesa y liturgia y un lote de herramientas de hierro. El conjunto de materiales de esta sepultura ha sido fechado a finales del siglo IV o principios del siglo V. La contextualización arqueológica de los frenos de Fuentespreadas es particularmente interesante para los problemas cronológicos que suscita toda la serie que presentamos.

El frenum queda por tanto constituído de un filete articulado por medio de dos cañones y dos anillas, dos camas con enganche de montante y dos anillos portarriendas ${ }^{24}$ (fig. 5). En determinados casos se utilizaba también un filete de palillos (en el exterior), aunque frecuentemente se ha perdido. Este filete de palillos es evidente en documentos tales como el mosaico de Amoris de Dueñas o la tumba de Vega Baja en Toledo, ya citados ${ }^{25}$ (fig. 1). La cabezada deberá estar constituida también por una testera, una muserola y una frontalera para que la embocadura responda correctamente a su precisa funcionalidad con la necesaria sujeción y, a la vez, movilidad (fig. 2).

Creemos que el sistema descrito, es simple y adecuado a las cabezadas utilizadas en la vida cotidiana, esencialmente de los caballos de parada. Las representaciones de esculturas ecuestres, por ejemplo del Alto Imperio, o los mosaicos con estos temas del Bajo Imperio y la antigüedad tardia, nos muestran unos tipos de cabezadas complejas y muy ornamentadas, sobre todo debido a la aparición de una gargantilla de vivos colores, que no debieron ser las utilizadas a diario. Al igual que tampoco se enjaezaban a diario los caballos del siglo XVIII y XIX con toda la parafernalia habitual en desfiles, demostraciones, etcétera. Caso diferente es el de los caballos destinados a enganche que requieren de una cabezada y un arnés mucho más complejos para su sujeción, que los destinados a la monta.

Evidentemente como hemos visto más arriba, son muchos los tipos de bocados que existen y que incluso se conocen para la antigüedad tardía, y particularmente la época visigoda. Sin embargo sus técnicas distan mucho de los frenos que nos proponemos estudiar y no deseamos alargarnos más sobre estas cuestiones aquí.

\section{LOS OBJETOS A ESTUDIAR: DEFINICIÓN, PROBLEMAS Y CONTEXTO}

Los apartados precedentes introductorios a la problemática de estas piezas, nos permiten pasar ya al estudio pormenorizado de ellas. En primer lugar cabe

24 Véanse las figs. 1 y 2 referidas a los detalles de la cabezada y al mosaico de Dueñas.

25 Cf. nota 11. 

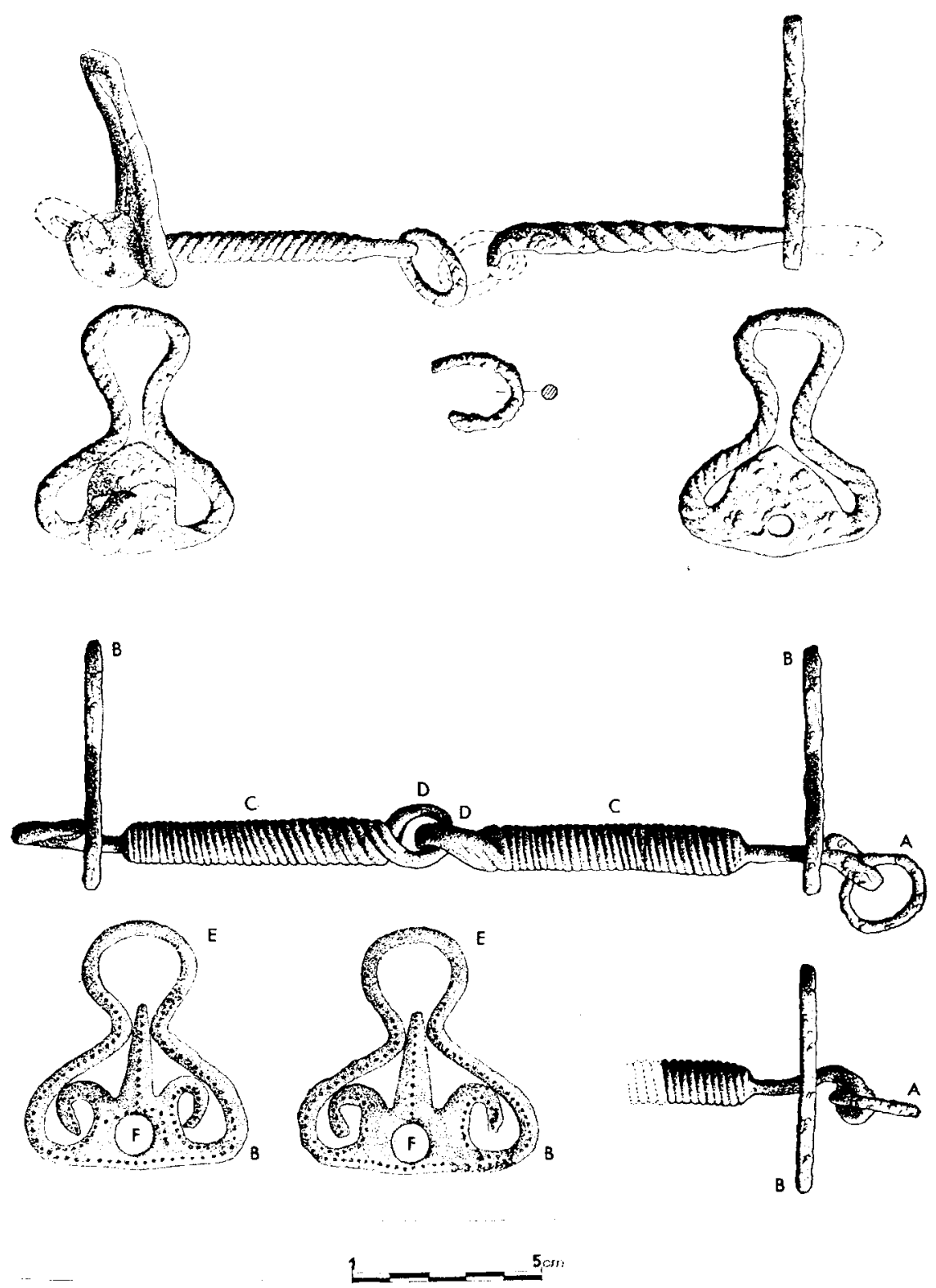

Fig. 4. Frenos procedentes de la sepultura $n^{\circ} 1$ de Fuentespreadas (dibujo según

L. Caballero, 1974). Vocabulario de las partes que componen el freno: $A$, anilla portarriendas; $B$, cama; $C$, cañón; $D$, anilla (de articulación de los cañones); $E$, enganche de montante; $F$, perforación del paso de filete. 
destacar la homogeneidad de cada uno de los grupos que hemos establecido. Estos grupos, tal como veremos más adelante, se definen por la propia morfologia y por su decoración.

Todas las camas tienen unas características comunes que vienen dadas por la presencia de un enganche de montante y una perforación de paso de filete (fig. 5). Algunas de ellas han sido fabricadas en hierro batido, pero en su mayoria son en bronce. En este último caso pueden haber sido recortadas sobre una plancha o pueden ser producto de fundición.

La perforación circular permitía el paso de cada uno de los cañones del filete, de los cuales pendian a la vez los anillos portarriendas, que tal como su nombre indica sujetaban las riendas. En muchos casos esta perforación se encuentra taponada por restos férreos que señalan la existencia de un filete o cañón de hierro, casi siempre hoy perdido. Cuando la perforación está completamente limpia, se observan frecuentemente señales de uso y desgaste. En las camas circulares con una decoración geométrica, esta perforación está situada en el centro de la pieza y se remarca por medio de una moldura. Cuando las camas pertenecen a grupos con decoración animal o figurativa, el orificio se ve desplazado hacia la parte inferior del objeto, por regla general en la zona donde la ornamentación pierde importancia. Esta particularidad es clara sobre todo en las camas con motivos ornamentales exentos. En algunos casos la separación entre la decoración principal y la perforación se hace por medio de una moldura rectilínea horizontal que organiza a la vez la superficie ornamental en dos registros.

El enganche de montante, también denominado enganche de carrillera, ojo o sujetamozo, tiene la función de ligar todo el freno a la cabezada. Su función obliga a que se sitúe en la parte superior de la cama, respondiendo a la vez a una preocupación por la simetría decorativa. Tan sólo en un caso, en la cama procedente de Muradela (Orense) ( $n^{\circ} 39$ ), el enganche de montante se halla desplazado en la parte izquierda de la cama. La mayoría de camas de tipo circular llevan un enganche de montante rectangular, aunque puede también ser cuadrangular o trapezcidal. En el caso de aquellas camas con decoración exenta, la mayoría de animales en posición heráldica, el enganche de forma triangular viene determinado por la propia omamentación. Al igual que en las perforaciones de paso de filete, en los enganches de montante se observan frecuentemente trazos de uso y desgaste producidos por la carrillera.

Otra característica común a las camas que nos ocupan, es que el anverso presenta siempre una decoración (a excepción de las $n^{\circ} 1$ a 9), que puede responder a motivos geométricos, o bien a motivos figurados, incluso escenas. La presencia de una cama en cada extremo del filete, obliga a producir piezas idénticas o casi idénticas. $\mathrm{Si}$ la decoración es geométrica o de animales en posición heráldica, es posible que se utilizase el mismo molde, pero cuando la decoración hace referencia a équidos aislados o bien a équidos montados por un jinete, entonces el perfil del animal y del individuo mirarán hacia la izquierda o la derecha dependiendo de su situación en el freno. 


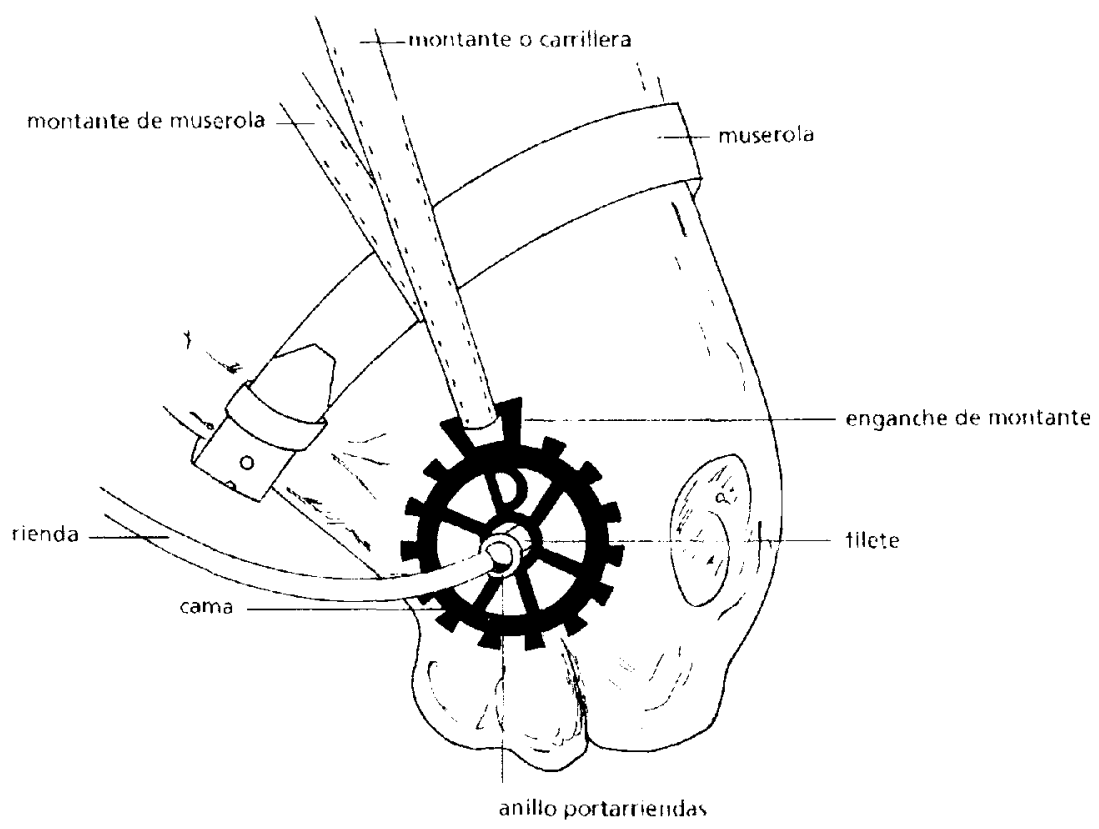

Fig. 5. Detalle de la cabeza de un caballo: situación y articulación del freno.

Todas estas ornamentaciones las analizaremos más detenidamente en los apartados dedicados a las interpretaciones, tras haber visto cada una de las piezas. Cabe señalar una particularidad en la fabricación. Cuando la cama en su globalidad no ha sido fundida en una sola pieza, se puede dar el caso, como es la cama de Monturque (Córdoba) ( $n^{\circ} 51$ ), que el anillo externo y el enganche de montante, pertenezcan a una misma colada de fundición y que la decoración central se deba a otro proceso de fundición. Posteriormente ambas piezas eran soldadas entre sí.

En cuanto al reverso, éste es liso y no presenta ninguna decoración. Por regla general ha sido pulido, aunque se pueden observar restos de rebabas de fundición.

Anteriormente, hemos citado cinco frenos completos, que son los que proporcionan información sobre su funcionalidad. Sin embargo existe un sexto objeto, procedente de Cubillas de Cerrato (Palencia) ${ }^{26}$. Todavía no hemos hecho mención

26 PALOL 1952, p. 302-303, fig. 6-7. 
de él, pues existen serias dudas en saber si se trata de un freno de caballo, o bien si pertenece a otro animal, e incluso si responde a la misma función. Las dimensiones de las camas circulares son menores de lo normal ( $n^{\circ} 25$ y 26 ), al igual que el vástago que une ambas camas. Este se situaba paralelo a otro también en bronce, hoy perdido, y su longitud es de 4'5 cm., siendo su sección circular. Estas dimensiones dificultan la interpretación de este objeto como freno de un caballo ${ }^{27} y$ deberiamos buscar otro tipo de solución, quizás perteneciente a un cuadrúpedo de menor tamaño o a un juguete. La problemática sigue abierta.

Deseamos denunciar que las camas de freno, son piezas que circulan en el comercio de antigüedades, mermando completamente su estudio y su contextualización tanto cronológica como histórica. El problema que plantea la práctica inexistencia de un contexto arqueológico, ha provocado que se fechen -la serie en general- dentro de un abanico cronológico amplio, entre los siglos IV al VI d.C. A continuación trataremos algunos de los problemas concretos relativos a la datación.

La fecha de finales del siglo II d.C. proporcionada por la moneda aparecida en la misma sepultura que el freno de Vega Baja (Toledo), nos parece relativamente temprana para la factura de estos objetos y quizás tenga que ser relativizada. Estas camas de tipo peltiforme recortadas sobre una plancha de bronce son conocidas en otras zonas del Imperio, como por ejemplo en la región del Danubio, aunque se desconocen sus cronologías precisas ${ }^{28}$. Parece claro que el freno de Vega Baja está marcando la fecha inicial de la serie de camas que nos ocupan, hacia finales del siglo ll o principios del siglo III d.C., aunque su período de utilización nos es desconocido.

Es muy posible que este tipo de camas peltiformes recortadas sobre una plancha de bronce fueran poco a poco sustituidas por las filiformes. Los hallazgos más representativos de este último tipo son los de Conímbriga y los de la necrópolis de Fuentespreadas ${ }^{29}$. Una de las camas filiformes de Conimbriga $\left(n^{\circ} 2\right)$ formaba parte de un contexto estratigráfico fechado entre los años 310-315 d.C. y los frenos de Fuentespreadas ( $n^{\circ} 8$ a 11) han sido datados a finales del siglo IV o principios del siglo $\mathrm{V}$ d.C. Nos encontramos por tanto ante un segundo momento de fabricación, para las piezas filiformes. Otro documento importante, al que ya nos hemos referido, es el mosaico de Dueñas, con la representación de una doble cabezada y un freno, precisamente filiforme y con filete de palillos. Aunque este mosaico no tiene

27 PALOL 1952, p. 302-303, fig. 6-7, la posibilidad de que se trate de una hebilla de cinturón no la consideramos plausible.

28 Vega Baja: Palol 1972, p. 136-142, fig. 9, lám. IV. 1. Palol 1989, p. 48-49, fig. 11.

29 Fuentespreadas: Caballero, 1974. Para Conímbriga: J. Alarcäo, R. Etienne, A.M. Alarcá y S. Da PONTE, Fouilles de Conimbriga, VII. Trouvailles diverses. Conclusions générales, Paris, 1979, p. 103-104, lám. XXII. 99. 
una datación absoluta, sí parece situarse hacia el segundo cuarto o mediados del siglo IV d.C. La relativa homogeneidad de la documentación aducida, permite hipotetizar un inicio del proceso de fabricación de estas camas en los primeros años del siglo del siglo IV perdurando hasta principios del siglo $\mathrm{V}$.

Las camas filiformes debieron convivir durante un cierto período de tiempo con las camas circulares. El punto de referencia viene dado por ejemplares, tales como los hallados en Fuentespreadas, puesto que en uno de los frenos aparece ya una preocupación ornamental diferente al resto de camas. El modo de fabricación difiere de las anteriormente mencionadas. Por regla general han sido fundidas y retocadas a lima, presentando variadas ornamentaciones de tipo geométrico. En primer lugar cabe destacar la decoración calada en forma de escudo o arco de herradura que aparece en varias de las camas que estudiamos, como por ejemplo en las camas de Pollentia ( $n^{\circ} 29-30$ y $31-32$ ), la de procedencia desconocida del Museo de Vic ( $n^{\circ} 33$ ), o la conservada en el Museo Arqueológico de Barcelona $\left(n^{\circ}\right.$ 35) ${ }^{30}$. Este tipo de calado escutiforme es muy frecuente en los broches de cinturón del siglo IV d.C, tan habituales en la región del Duero ${ }^{31}$, pero cuya dispersión empieza a ser grande, además de observarse en objetos relativamente más tardios ${ }^{32}$. Diversas formas caladas, tanto vegetales como geométricas, aparecen también en otras guarniciones de caballos, como las phalerae, y en escenas de caza de los mosaicos de los siglos IV y $V$ d.C.

En lo que a las camas con inscripción respecta, éstas aportan pocos elementos cronológicos. En aquellas que presentan una inscripción calada, las letras suelen llevar un apéndice o pie, que podriamos interpretar como un índice de datación tardío en el siglo IV d.C. La aparición del crismón, sólo o con el alpha y omega, sitúa también las camas en época post-constantiniana. La fórmula ex oficina, generalizada a partir del siglo IV d.C., perdura hasta el siglo VIII d.C. ${ }^{33}$. Es posible también, que la cama en la que aparece el nombre de Tagus $\left(n^{\circ} 48\right)$, sea un índice cronológico interesante, puesto que es un nombre muy extendido dentro de la onomástica equina a partir del siglo IV d.C.

30 PALOL 1952, p. 302, fig. 2. 3-4. P. de PALOL, "Una pieza de arnés hispanovisigoda en el Museo Arqueológico de Barcelona", Ampurias, XXI, 1959, p. 329-330, fig. 1 (a partir de ahora PALOL 1959). PALOL 1989, p. 35-44, fig. 1-2.

${ }_{31}$ P. de PALOL, "La necrópolis de San Miguel del Arroyo y los broches hispanorromanos del siglo IV», BSAA, XXXIV-XXXV, 1968-1969, p. 93-161. El tipo de calado escutiforme es muy habitual en los objetos los siglos IV y V. CABALLERO 1974, p. 39-55, insiste sobre el paralelismo de las camas y los broches.

32 La perduración de este tipo de motivos es muy larga y se observa particularmente en piezas de adomo personal de finales del siglo VI e incluso de principios del siglo VII. Tampoco se trata de un motivo exclusivamente hispánico, cf. F. ANDRÉ y G. MANGIN, "Les bijoux d'Arégonde", Dossiers de l'Archéologie, 32, 1979, p. 50-65.

${ }_{33}$ C. BALMELLE y J.P. DARMON, «L'artisan-mosaïste dans l'antiquité tardive. Réflexions à partir des signatures", Artistes, Artisans et Production artistique au Moyen-Age, vol. I, Les hommes, Paris, 1986 , p. 235-253. Precisan algunas cuestiones cronológicas acerca de las firmas. 
En cuanto a la serie de camas con decoración figurativa, ya sea zoomorfa o con escenas, cabe resaltar su diferencia respecto a la fabricación y al tratamiento de la ornamentación. Por regla general todas ellas han sido fundidas en bronce y en algunos casos la decoración central y el anillo son producto de diferentes coladas y posteriormente se han soldado entre si. La decoración es variada y responde a un trabajo originario, producido por artesanos y artistas buenos conocedores. El conjunto de piezas no es perfectamente homogéneo, pero no tenemos criterios lo suficientemente válidos para afinar posibles cronologias. Tan solo se puede destacar, tal como ya hemos avanzado y veremos más adelante, que esencialmente- su iconografía responde a un horizonte de los siglos IV al VI d.C., no exclusivo de Hispania, sino también habitual en el resto de las provincias del Imperio.

Con muchas reservas y antes de pasar al estudio pormenorizado de las piezas, podemos acercarnos a una primera conclusión relativa a la cronología. La utilización de las camas de freno que nos ocupan, encuentran sus antecedentes a finales del siglo II o principios del siglo III d.C., generalizándose su utilización a partir del siglo IV d.C. Creemos perduraron con una cierta seguridad, hasta el siglo VI d.C., aunque no descartamos que siguieran fabricándose hasta principios del siglo VIII d.C. ${ }^{34}$. Debemos tener en cuenta también, que además de los frenos de parada, a lo largo de los siglos VII y VIII d.C., se enjaezaron los caballos con pesados bocados.

\section{TIPOLOGIA, CLASIFICACIÓN E INVENTARIO}

Varios son los artículos referidos a este tipo de piezas escritos esencialmente por el Profesor Palol ${ }^{35}$, sin embargo el número ha ido en aumento y la dispersidad es grande (fig. 30), por ello hemos creído necesario hacer una relación a modo de inventario somero que proporcione una mejor visión de la documentación. El inventario se organiza por grupos según una clasificación temática y morfológica de las camas aunque no establece una tipología, pues no creemos sea necesario. En él hemos recopilado el máximo de piezas que nos son conocidas a través de las publicaciones y los museos, pero no cabe duda que muchas deberán sumarse con posterioridad pues no son del conocimiento público ${ }^{36}$.

34 No incluimos en este estudio el hallazgo de El Bovalar (Serós, Lérida) pues no ha sido publicado, pero según información del Profesor Palol su hallazgo se sitúa en los niveles estratigráficos de finales del siglo VII o principios del VIII.

35 P. de PALOL, "Bronces de arnés con representaciones zoomórficas", Ampurias, XV-XVI, 19531954, p. 279-292, 8 fig. (a partir de ahora PALOL 1953-54). Con una primera clasificación.

${ }_{36}$ Existen dos nuevas piezas con calados escutiformes en la Colección Montero (Sevilia) que no incluimos pues están en proceso de estudio por Joaquín Aurrecoechea. También sabemos de cuatro nuevas piezas procedentes de la región de Mérida (hoy interceptadas por la Policia Judicial), que no 
En este inventario sólo describimos someramente las caracteristicas morfológicas. Separadamente hacemos el estudio y la interpretación de cada tipo. La clasificación de los materiales sigue el siguiente orden:

- camas con decoración geométrica simple

- camas con decoración geométrica y crismón,

- camas con decoración geométrica e inscripción,

- camas con decoración zoomorfa: representaciones de un único caballo e inscripción,

- camas con decoración zoomorfa: representaciones de un único caballo,

- camas con decoración zoomorfa: representaciones de caballos afrontados,

- camas con decoración zoomorfa: representaciones de caballos y delfines,

- camas con decoración zoomorfa: representaciones de felinos,

- camas con decoración de escenas: representación de uenationes,

- camas con decoración de escenas: representaciones de caballos montados,

- camas con decoración de escenas mitológicas.

El inventario que sigue contempla la descripción ordenada del siguiente modo: un número correspondiente a nuestro catálogo, que es el que aparece, al mismo tiempo, en la figura donde se ilustra la pieza, la procedencia, el museo donde se conserva y su número de inventario. Le sigue el contexto de su hallazgo, si tiene alguna particularidad o interés, sino no consta. A continuación se indica el tipo de objeto y su material de fabricación en el caso de que sea diferente al bronce. Sigue una descripción somera que parte de la cama propiamente dicha y su ornamentación, para pasar luego al enganche de montante. Por último se indican las medidas, aunque en muchos casos éstas son desconocidas por tratarse de objetos perdidos o mal publicados, sin embargo, si se puede, se dan las dimensiones aproximadas y las ilustraciones se reproducen según esa escala aproximada que se ha obtenido por referencias.

\section{Camas con decoración geométrica simple}

Conocemos un total de treinta y cinco ejemplares de camas con decoración geométrica simple. Todas ellas han sido fundidas en bronce, a excepción de dos que son en hierro, y presentan las características generales descritas más arriba.

han llegado a tiempo para ser incluídas en este estudio. Para la comprobación de los $n^{\circ}$ del inventario y sus referencias es utij el listado que se sitúa al final de estas páginas, al igual que la confrontación con el mapa de dispersión: fig. 30. A partir de ahora utilizaremos las siguientes abreviaturas: IVDJ = Instituto Valencia de Don Juan (Madrid); MAB = Museo Arqueológıco de Barcelona; MAN = Museo Arqueológico Nacional (Madrid); RGZM = Römisch-Germanisches Zentralmuseum de Maguncia. 

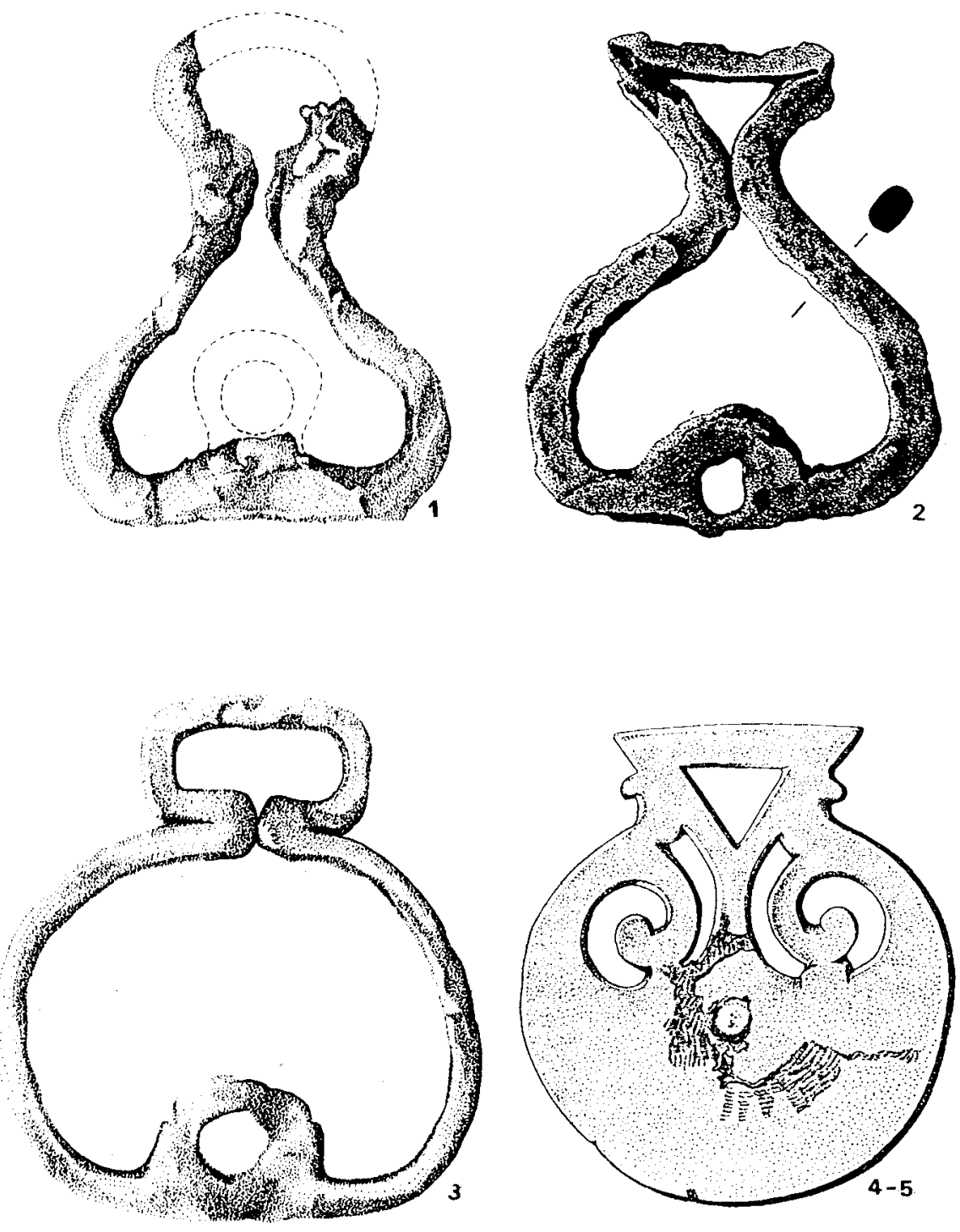

Fig. 6. Camas procedentes de: 1 a 3, Conímbriga; 4-5, Vega Baja. 
1.- Conímbriga (Portugal) ${ }^{37}$. Museo Monográfico de Conímbriga ( $n^{\circ}$ inv. A. 914). Hallazgo de las excavaciones anteriores a 1962. Cama de hierro batido, filiforme de sección rectangular. La parte inferior globular está sobremontada por un enganche de montante de forma circular, presentando una deformación de un "ocho". La perforación circular se hallaba situada en la parte inferior, hoy perdida. Dimensiones: $9^{\prime} 0 \mathrm{~cm}$. de alto y $6^{\prime} 8 \mathrm{~cm}$. de ancho.

2.- Conimbriga (Portugal) ${ }^{38}$. Museo Monográfico de Conimbriga ( ${ }^{\circ}$ inv. 70.282 ). Hallazgo procedente de un nivel estratigráfico fechado entre el 310-315 d.C. Cama de hierro batido. La parte inferior de forma glóbulo-triangular está sobremontada por un enganche de montante triangular. La base presenta una perforación circular muy marcada. Dimensiones: 7'8 $\mathrm{cm}$. de diámetro y $9^{\prime} 2 \mathrm{~cm}$. de altura total.

3.- Conímbriga (Portugal) ${ }^{39}$. Museo Monográfico de Conímbriga ( $n^{\circ}$ inv. A. 915). Hallazgo procedente de las excavaciones anteriores a 1962. Cama de hierro batido de tipo filiforme y sección rectangular, compuesta de un cuerpo central casi circular sobremontado por un enganche de montante rectangular. En la parte inferior del objeto se sitúa la perforación circular destinada al filete. Dimensiones: 9'6 cm. de ancho y $8^{\prime} 9 \mathrm{~cm}$. de alto.

4.- Vega Baja (Avda. de la Reconquista, Toledo) ${ }^{40}$. Museo de Santa Cruz, Toledo ( $\mathrm{n}^{\circ}$ inv. 2279). Hallazgo procedente de una sepultura asociada a diferentes materiales y a una moneda de Marco Aurelio, fechada entre los años 161-180 d.C. Cama recortada sobre plancha de bronce de tipo peltiforme, con decoración calada de dos volutas. La perforación se sitúa en la parte central. El enganche de montante triangular presenta dos protuberancias en los perfiles externos. Dimensiones: $8^{\prime} 5 \mathrm{~cm}$. de altura, $7^{\prime} 8 \mathrm{~cm}$. de diámetro y $0^{\prime} 2 \mathrm{~cm}$. de espesor.

5.- Vega Baja (Avda. de la Reconquista, Toledo). Museo de Santa Cruz, Toledo ( $n^{\circ}$ inv. 2280). Igual a la precedente $\left(n^{\circ} 4\right)$, pertenece al mismo freno.

6.- Clunia (Burgos) ${ }^{41}$. Museo Arqueológico de Burgos. Freno hallado por Blás Taracena en 1933 en las excavaciones realizadas en la habitación 62 de la casa $n^{\circ} 1$ de la ciudad romana. Cama rigida recortada sobre plancha de bronce. Perforación circular central. El enganche de montante triangular en la parte superior presenta dos protuberancias en los perfiles externos que lo separan claramente de la zona circular. La articulación del filete se hace por medio de dos anillas en la parte central. Los extremos de dicho filete atraviesan ambas camas y presentan exteriormente dos argollas de sujeción. Dimensiones desconocidas.

7.- Clunia (Burgos). Museo Arqueológico de Burgos. Cama igual a la precedente, corresponde al mismo freno $\left(n^{\circ} 6\right)$.

8.- Fuentespreadas (Zamora) ${ }^{42}$. Hallazgo procedente de la sepultura $\mathrm{n}^{\circ} 1$ de la necrópolis, fechada a finales del siglo IV o principios del siglo $V$, junto a las camas $n^{\circ} 9,10$ y 11 . Pertenece

${ }^{37}$ Isabel PEREIRA, "Elementos de freios tardo-romanos de Conimbriga", Conimbriga, IX, 1970, p. 7 14, 2 lám., cf. p. 7, lám. II. 2.

38 Alarcáo, Etienne, Alarcáo y da Ponte, Fouilles de Conimbriga..., op. cit., p. 104, lám. XXII. 99.

39 Pereira, "Elementos de freios...", op. cit., p. 8, lám. Il.1.

40 PaLol 1972, p. 136, 139-149, fig. 8, lám. III, 2, IV. 1

41 PALOL 1989 , p. 48-49, fig. 11.

42 Caballero 1974 , p. 74-76, fig. 18.1. 
al mismo freno que la $n^{\circ} 9$. Cama de hierro batido, de tipo filiforme. Se compone de dos partes globulares en forma de "a ocho" deformada. La perforación circular está situada en el ensanchamiento de la parte inferior. Dimensiones: $6^{\prime} 7 \mathrm{~cm}$. de altura y $5^{\prime} 4 \mathrm{~cm}$. de anchura.

9.- Fuentespreadas (Zamora). Cama de hierro batido y filiforme, perteneciente al mismo freno que la $\mathrm{n}^{\circ} 8$. Mismas dimensiones que la precedente.

10.- Fuentespreadas (Zamora) ${ }^{43}$. Hallazgo procedente de la sepultura $n^{\circ} 1$ de la necrópolis, fechada a finales del siglo IV o principios del siglo $V$, al igual que las camas $n^{\circ} 8,9 y$ 11. Pertenece al mismo freno que la $n^{\circ} 11$. Cama filiforme en hierro. Compuesta de dos partes globulares en forma de "a ocho" deformada. La perforación circular se sitúa en un ensanchamiento de la parte inferior y finaliza por medio de tres digitaciones evocando un motivo vegetal trifoliado. Los perfiles exteriores y del motivo vegetal se hallan recorridos por medio de una decoración basada en una línea de puntos. Dimensiones: $6^{\prime} 8 \mathrm{~cm}$. de alto y $6^{\prime} 5$ $\mathrm{cm}$. de ancho.

11.- Fuentespreadas (Zamora). Cama en hierro filiforme perteneciente al mismo freno que la precedente $\left(n^{\circ}\right.$ 10). Mismas dimensiones.

12.- Procedencia desconocida ${ }^{44}$. Museo Episcopal de Vic (Gerona) ( $n^{\circ}$ inv. 16490). Cama recortada sobre plancha de bronce, de tipo circular, ornamentada con una línea contínua que recorre el perfil circular. Una línea idéntica remarca la perforación circular situada en la parte central. En la zona superior de la cama se sitúa un enganche de montante robusto de forma circular. Dimensiones: $8^{\prime} 0 \mathrm{~cm}$. de diámetro y $11^{\prime} 3 \mathrm{~cm}$. de altura.

13.- Numancia (Soria) ${ }^{45}$. Museo Numantino ( $n^{\circ}$ inv. 6515). Cama fundida con anillo externo que encierra una estrella de cuatro puntas. En el centro aparece la perforación circular. En la parte superior se sitúa el enganche de montante semicircular con perforación circular. Dimensiones desconocidas.

14.- Numancia (Soria) ${ }^{46}$. Museo Numantino ( $n^{\circ}$ inv. 6514). Cama circular con anillo externo que encierra una estrella de cuatro puntas en cuyo centro se sitúa la perforación circular. En la parte superior se halla el enganche de montante de forma semicircular con perforación circular. Dimensiones desconocidas.

15.- Numancia (Soria) ${ }^{47}$. Museo Numantino ( $\mathrm{n}^{\circ}$ inv. 6506). Cama circular. Fracturada en la parte superior, ha perdido el enganche de montante. Cinco radios se reúnen en el centro presentando una moldura perforada circularmente. Por la forma del objeto podemos deducir que existió un sexto radio que se situaria por debajo del enganche de montante. Dimensiones desconocidas.

16.- Castro de Seur (Ortigueira, Galicia) ${ }^{48}$. Facultad de Filosofía y Letras de Santiago de Compostela (?). Cama circular con perfil externo recorrido de pequeñas digitaciones. Dei

43 Caballero 1974, p. 74-76, fig. 18.2.

44 PALOL 1989, p. 36 y 44 , fig. 4.

45 PALOL 1952, p. 306, fig. 5. 14.

46 PALOL 1952, p. 306, fig. 5. 13.

47 PALOL 1952, p. 306, fig. 5. 15.

48 PALOL 1953-54, p. 280-281, fig. I. a. 

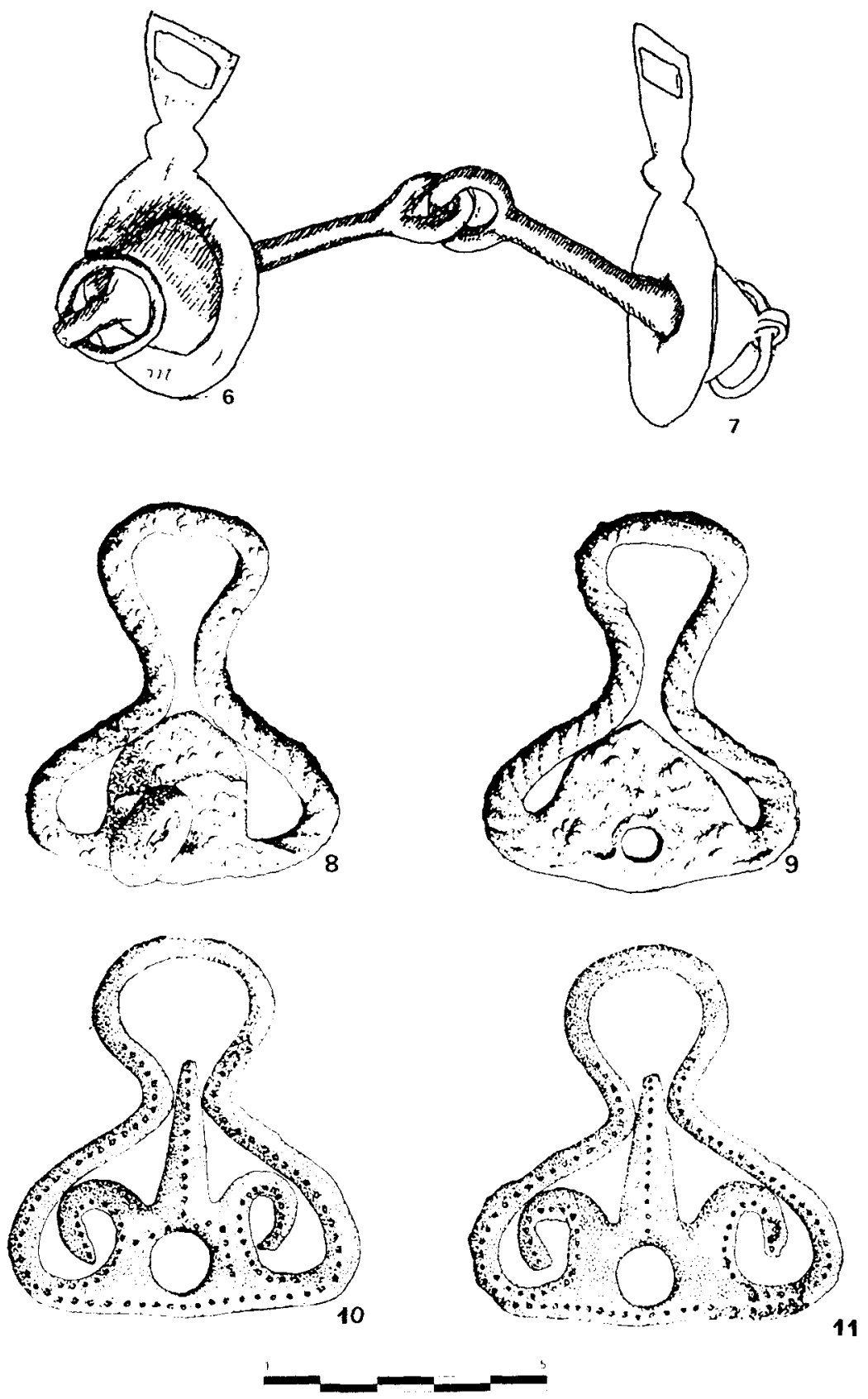

Fig. 7. Camas procedentes de: 6-7, Clunia; 8 a 11, Fuentespreadas. 
anillo externo parten seis radios potenzados que se reúnen en el centro alrededor de la perforación circular. Esta última está taponada por residuos férreos. El enganche de montante fracturado y perdido. Dimensiones: 8 ' $4 \mathrm{~cm}$. de diámetro.

17.- Procedencia desconocida ${ }^{49}$. MAN ( $n^{\circ}$ inv. 9403). Cama circular cuyo anillo exterior encierra ocho radios rectos, uno de ellos fracturado y otro perdido. En el centro la perforación circular se remarca por una moldura en altura. La parte inferior se halla fracturada, al igual que el enganche de montante que era de forma rectangular. El vástago conservado de dicho enganche de montante presenta un pequeño orificio en el ángulo superior izquierdo. Dimensiones: $8^{\prime} 5 \mathrm{~cm}$. de diámetro y $8^{\prime} 0 \mathrm{~cm}$ de altura.

18.- El Algallarin (Adamuz, Córdoba) ${ }^{50}$. Museo Arqueológico de Córdoba ( $\mathrm{n}^{\circ}$ inv. 28.170). Cama circular cuyo anillo presenta tanto en el perfil externo como interno pequeñas digitaciones. Toda la superficie de este anillo se halla ornamentada con pequeños trazos lineales puntilleados. Ocho radios potenzados y decorados con pequeñas líneas paralelas se reúnen en el centro alrededor de la perforación circular. Ésta está taponada por resíduos férreos del filete. El enganche de montante es de tipo cuadrangular y los brazos laterales presentan una esquematización muy deformada de dos delfines. La cola simplemente sugerida, el hocico apoyándose en el exterior del anillo y el ojo desplazado hacia el centro de la figura. Dimensiones: 8 ' $8 \mathrm{~cm}$. de diámetro y $3^{\prime} 1 \mathrm{~cm}$. de altura con el enganche de montante.

19.- Conímbriga (Portugal) ${ }^{51}$. Museo Monográfico de Conímbriga ( $\mathrm{n}^{\circ}$ inv. 70.281). Hallada en un nivel estratigráfico revuelto. Cama circular con anillo ornamentado de pequeñas líneas incisas y paralelas, que se repiten en el enganche de montante que es de forma trapezoidal. La zona central está ocupada por diez radios ligeramente curvados reunidos alrededor de la perforación del paso de filete. Entre el enganche y el anillo externo se sitúa un pequeño orificio circular. En el reverso se conservan todavia escorias de hierro pertenecientes a los cañones. Dimensiones: $6^{\prime} 2 \mathrm{~cm}$. de diámetro y $8^{\prime} 0 \mathrm{~cm}$. de altura.

20.- Procedencia desconocida ${ }^{52}$. IVDJ. Cama circular recortada sobre una plancha de bronce. Ocho radios potenzados en uno de sus extremos se reúnen en el centro alrededor del paso de filete. Éste, más grande de lo habitual, presenta marcas de uso. El noveno radio lo forma el mismo enganche de montante y es de forma triangular. Entre el paso de filete y el enganche se sitúa, en el mismo eje, un orificio circular. Dimensiones: $8^{\prime} 0 \mathrm{~cm}$. de diámetro y $11^{\prime} 0 \mathrm{~cm}$. de altura.

21.- Procedencia desconocida ${ }^{53}$. MAB ( $n^{0}$ inv. 5392). Cama circular que presenta diez radios curvos, ligeramente potenzados, girando alrededor de la perforación circular del paso de filete señalada por medio de una moldura en altura. El enganche de montante, actualmente fracturado, era de forma rectangular. Dimensiones: $7^{\prime} 9 \mathrm{~cm}$. de diámetro y $9^{\prime} 0 \mathrm{~cm}$. de altura.

49 PALOL $1953-54$, p. 280 , fig. I. c.

50 A. MARCos Pous y A.M. VICENT DE MARCos, "Dos camas de freno de caballo paleocristianas del Museo Arqueológico de Córdoba y su simbolismo", Corduba Archeologica, 11, 1981, p. 23-45, cf. p. 3244.

Alarcào, Etienne, Alarcáo y Da Ponte, Fouilles de Conimbriga, VII..., op. cit., p. 104, lám. XXI. 98.

PALOL 1952, p. 304, fig. 3. 9.

53 PALOL 1953-54, p. 280, fig. I. b. 
22.- Menorca, lugar de hallazgo no determinado ${ }^{54}$. Lugar de conservación desconocido, quizás MAN. Cama circular que presenta una decoración calada de tipo cruciforme intercalando radios entre los brazos. Una línea incisa continua recorre el anillo externo. El paso de filete es señalado por una moldura circular. El enganche de montante es de forma rectangular. Dimensiones desconocidas.

23.- Provincia de Sevilla, lugar no determinado ${ }^{55}$. RGZM. Cama circular cuyo perfil externo del anillo está ornamentado con dieciocho pequeñas digitaciones globulares que enmarcan el enganche de montante, este último casi rectangular. En el centro se sitúa un cuadrado sobre la punta en cuyos ángulos aparece un circulo calado. La perforación del paso de filete se remarca por medio de una moldura. El anverso y reverso del paso de filete muestran profundos trazos de uso. Dimensiones: $5^{\prime} 3 \mathrm{~cm}$. de diámetro, $6^{\prime} 8 \mathrm{~cm}$. de altura, $0^{\prime} 4 \mathrm{~cm}$. de espesor, 65'790 gr. de peso.

24. - Vilauba (Camós, Gerona) ${ }^{56}$. Cama circular con decoración geométrica. En el perfil exterior del anillo se remarcan pequeños trazos rectilíneos y paralelos, dispuestos de forma heterogénea. A partir de la perforación circular del paso de filete se organiza una decoración calada en forma de cruz. Cada uno de los cuatro brazos finaliza en tres digitaciones. La central de tipo rectangular, las dos laterales evocan motivos vegetales esquematizados o bien pequeñas cabezas de caballos. Una perfecta lectura se hace dificil debido al deterioro y al uso de la cama y a que ha sido limpiada pero no restaurada. El enganche de montante es de forma rectangular. Dimensiones: $8^{\prime} 4 \mathrm{~cm}$. de altura y $6^{\prime} 4 \mathrm{~cm}$. de diámetro.

25.- Cubillas de Cerrato (Palencia) ${ }^{57}$. IVDJ. Cama recortada sobre plancha de bronce. El anillo externo de la cama presenta veinte pequeñas digitaciones rectangulares que enmarcan el enganche de montante. El anverso del anillo está recorrido por tres líneas incisas paralelas. La decoración, que gira alrededor de la perforación circular del paso de filete, está constituida por doce radios que forman una estrella de seis puntas. El enganche de montante es de forma triangular. Esta cama formaba parte del mismo freno que la $n^{\circ} 26$, puesto que se consenvan los cañones. Dimensiones: $6^{\prime} 0 \mathrm{~cm}$. de diámetro.

26.- Cubillas de Cerrato (Palencia). Igual a la precedente $n^{\circ} 25$ y perteneciente al mismo freno.

27.- Provincia de Palencia, lugar de hallazgo no determinado ${ }^{58}$. Colección particular de E. Fontaneda (Aguilar de Campoo, Palencia). Hallazgo conjunto con la $n^{\circ} 28$. Se conserva el freno completo con sus dos camas, cañones, anillas de articulación y anillos portarriendas. Cama circular cuyo anillo externo está ornamentado con una línea de "S". En el centro, la decoración está formada por seis triángulos yuxtapuestos y apoyados en sus ángulos. En el centro de cada uno de ellos aparecen unos círculos concéntricos. El enganche de montante

54 PALOL 1952, p. 302, fig. 2. 5.

55 Ripol.., L'archéologie funéraire de Bétique..., op. cit., p. 228, fig. 35,2, lám. II, 2a y 2 b.

56 A. ROURE i BonAventuRA, et alii, La villa romana de Vilauba (Camós). Estudi d'un assentament rural (Campanyes de 1979-1985), Centre d'Investigaciones arqueològiques de Girona, Sèrie Monogràfica, 8, Gerona, 1988, p. 86, 90 y 118, fig. 57-21.

57 PALOL 1952, p. 302-303, fig. 2. 6-7, 3. 6-7.

58 PALOL 1967, p. 236-240, lám. IV-VI. 

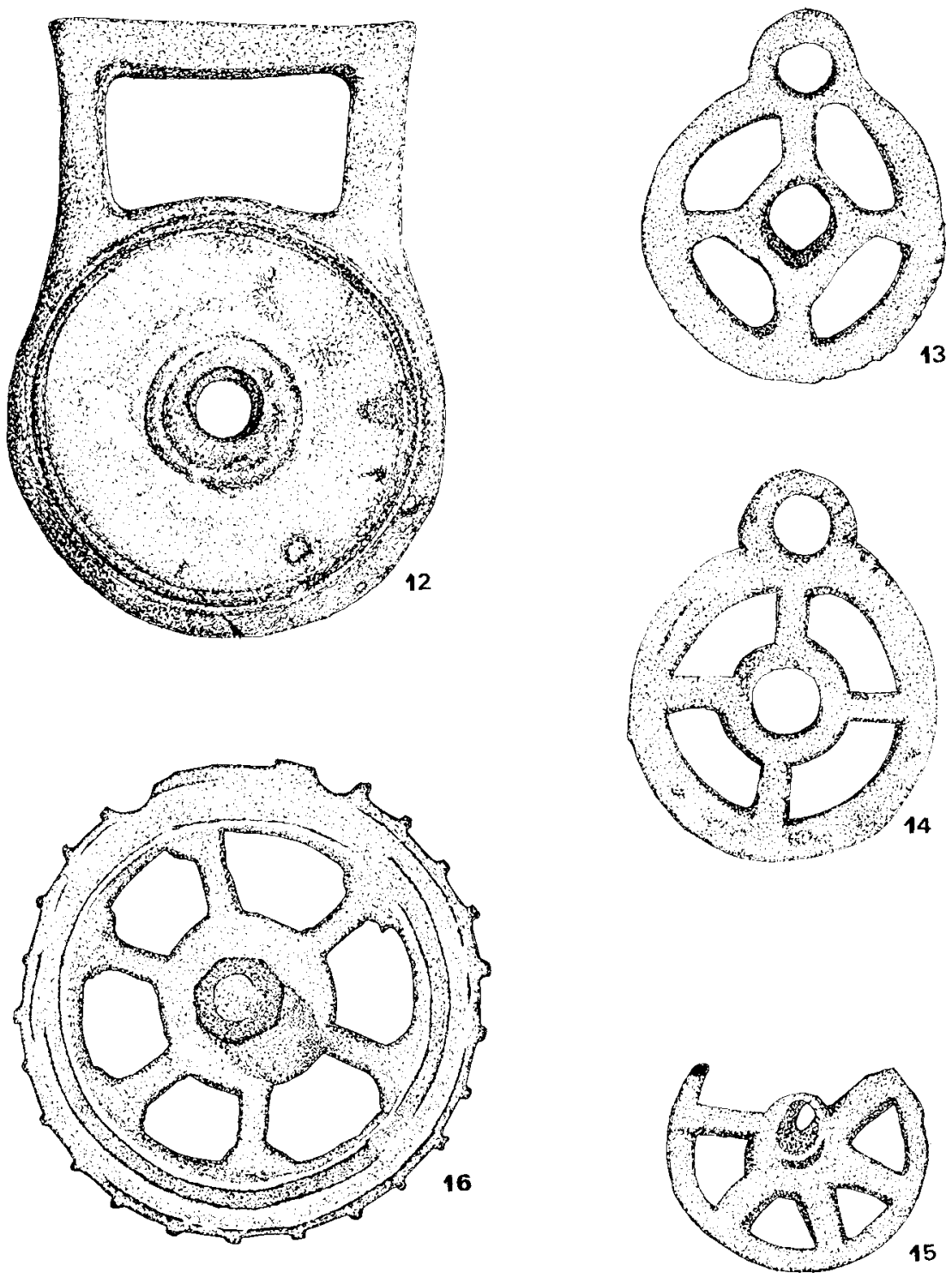

Fig. 8. Camas procedentes de: 12, procedencia desconocida; 13 a 15, Numancia; 16 , Castro de Seur. 
es de forma trapezoidal y presenta en sus ángulos superiores dos círculos concéntricos. La perforación circular del paso de filete se señala por medio de una moldura. Dimensiones: 5 '5 $\mathrm{cm}$. de diámetro y $7^{\prime} 0 \mathrm{~cm}$. de altura.

28.- Provincia de Palencia, lugar de hallazgo no determinado. Colección particular de $E$. Fontaneda (Aguilar de Campoo, Palencia). Pertenece al mismo freno que la cama anterior, $\mathrm{n}^{\circ}$ 27, y se sitúa en el lado izquierdo. La pieza está fracturada y sólo conserva parte del arranque de los radios de la zona central y la perforación para el paso de filete. El motivo geométrico de esta cama, por ser diferente, no hace juego con la anterior. Las dimensiones son desconocidas aunque menores a las de la $\mathrm{n}^{\circ} 27$. No se dibuja.

29.- Pollentia (Mallorca) ${ }^{59}$. Museo de la Lonja, Palma de Mallorca. Cama circular cuyo anillo externo se halla recorrido por dos lineas incisas paralelas. La parte central -fracturadapresenta una decoración calada de nueve escudos o arcos de herradura girando alrededor de la perforación para el paso del filete. El enganche de montante adopta una forma ligeramente arqueada y asimétrica. Dimensiones desconocidas.

30.- Pollentia (Mallorca). Museo de la Lonja, Palma de Mallorca. Cama igual a la precedente $n^{\circ} 29$, correspondiente al mismo freno. Fracturada en su parte inferior de la decoración central. Conserva restos del cañon de hierro que pasaba por la perforación circular.

31. - Pollentia (Mallorca) ${ }^{60}$. MAB. Cama circular cuyo perfil exterior está recorrido parcialmente por pequeñas lineas paralelas incisas. La parte central del objeto presenta una decoración calada que gracias a ocho radios dibujan arcos de herradura deformados. La perforación para el paso del filete se sitúa en el centro y está señalada por medio de una moldura. El enganche de montante es de forma globular deformada. Dimensiones: $7^{\prime} 0 \mathrm{~cm}$. de diámetro y $8^{\prime} 5 \mathrm{~cm}$. de altura.

32.- Pollentia (Mallorca). MAB. Cama igual a la precedente, $n^{\circ} 31$, y correspondiente al mismo freno.

33.- Procedencia desconocida ${ }^{61}$. Museo Episcopal de Vic (Gerona) ( $n^{\circ}$ inv. 16489). Fragmento de la zona superior de una cama circular. El perfil externo del anillo está ocupado por una serie de digitaciones globulares y dos líneas paralelas recorren la superficie del anverso. Conserva parte de la superficie interna decorada y calada por medio de radios que dibujan arcos de herradura. El enganche de montante presenta una forma rectangular. Dimensiones: $9^{\prime} 0 \mathrm{~cm}$. de diámetro y $2^{\prime} 0 \mathrm{~cm}$. de altura el enganche del montante.

34.- Procedencia desconocida ${ }^{62}$. MAN. Cama circular fracturada por la parte inferior. El anillo externo está recorrido por una serie de digitaciones globulares y dos líneas incisas paralelas. La decoración de la zona central ha sido calada y presenta una esquematización vegetal. La perforación del paso de filete se halla taponada por concreciones ferrosas. El enganche de montante es de forma rectangular. Dimensiones: $8^{\prime} 5 \mathrm{~cm}$. de diámetro y $9 \mathrm{~cm}$. de altura.

\footnotetext{
9ALOL 1952, p. 301-302, fig. 2. 1-2.

PALOL 1952, p. 302, fig. 2. 3-4.

PALOL 1989, p. 36, fig. 3.

PALOL 1952, p. 304-305, fig. 3. 10.
} 
35.- Procedencia desconocida ${ }^{63}$. MAB ( $\mathrm{n}^{\circ}$ inv. 5391). Cama circular cuya decoración central se basa en un cuadrado sobre la punta que encierra un motivo cruciforme determinando escudos $o$ arcos de herradura que giran alrededor de un botón central. La perforación para el paso del filete se sitúa en la parte inferior de la pieza. El enganche de montante de forma rectangular está señalado por dos digitaciones. Dimensiones: $6^{\prime} 0 \mathrm{~cm}$. de diámetro y $8 ' 5 \mathrm{~cm}$. de altura.

\section{Camas con decoración geométrica y crismón}

El número total de camas de este tipo conocidas asciende a seis ejemplares. Todas ellas presentan una decoración geométrica simple basada en la presencia de un crismón.

36.- Provincia de Soria, lugar de hallazgo no determinado ${ }^{64}$. Colección particular Monteverde (Burgos). Cama circular cuyo anillo externo está ornamentado por una serie de líneas sinuosas con racimos de uvas. La parte central está ocupada por un crismón que presenta en sus brazos una decoración de lineas sinuosas, parcialmente perdida. La perforación circular para el paso del filete se señala por medio de una moldura. El enganche de montante es de forma trapezoidal. Dimensiones: $88^{\prime} 0 \mathrm{~cm}$. de diámetro y $10 \mathrm{~cm}$. de altura.

37.- Procedencia desconocida ${ }^{65}$. MAN. Cama circular cuyo anillo exterior presenta cinco digitaciones rectangulares. La superficie central está ocupada por un crismón de brazos potenzados. El paso de filete presenta concreciones férreas. El enganche de montante fracturado y perdido. Dimensiones: $8^{\prime} 0 \mathrm{~cm}$. de diámetro.

38.- Procedencia desconocida ${ }^{66}$. IVDJ. Cama circular cuyo anillo presenta una línea de círculos puntilleados y una serie de digitaciones en el perfil interior. Este anillo encierra un crismón de brazos ligeramente pontez̧ados. En el centro se sitúa la perforación para el paso del filete. El enganche de montante es de forma rectangular. Dimensiones: $6^{\prime} 0 \mathrm{~cm}$. de diámetro y $7,5 \mathrm{~cm}$. de altura.

39.- Muradela (Mourazos, Orense) ${ }^{67}$. Museo Arqueológico de Orense. Cama circular fracturada por la zona del enganche de montante, hoy perdido. El perfil del anillo externo se halla recorrido por dieciseis digitaciones circulares decoradas con un circulo concéntrico. Este mismo motivo se repite en el reverso del anillo y está enmarcado por dos lineas dobles paralelas. El crismón de la zona central presenta los mismos círculos concentricos en toda la superficie. El paso de filete es circular y está remarcado por una moldura. Hay que señalar que el enganche de montante estaba descentrado en relación al eje de simetria de la cama. Dimensiones: $11^{\prime} 2 \mathrm{~cm}$. de diámetro y $0^{\prime} 3 \mathrm{~cm}$. de espesor.

63 PALOL 1953-54, p. 280, fig. I. d.

64 PALOL 1989, p. 283, fig. 4 a y 3.

65 Palol 1952, p. 307-308, fig. 4. 16.

66 PALOL 1952, p. 308, fig. 4. 17.

67 X. Rodriguez y A. SeARA, "Bronce de arnés con tema paleocristiano", Boletin Auriense, XII, Orense, 1982, p. 301-304. 

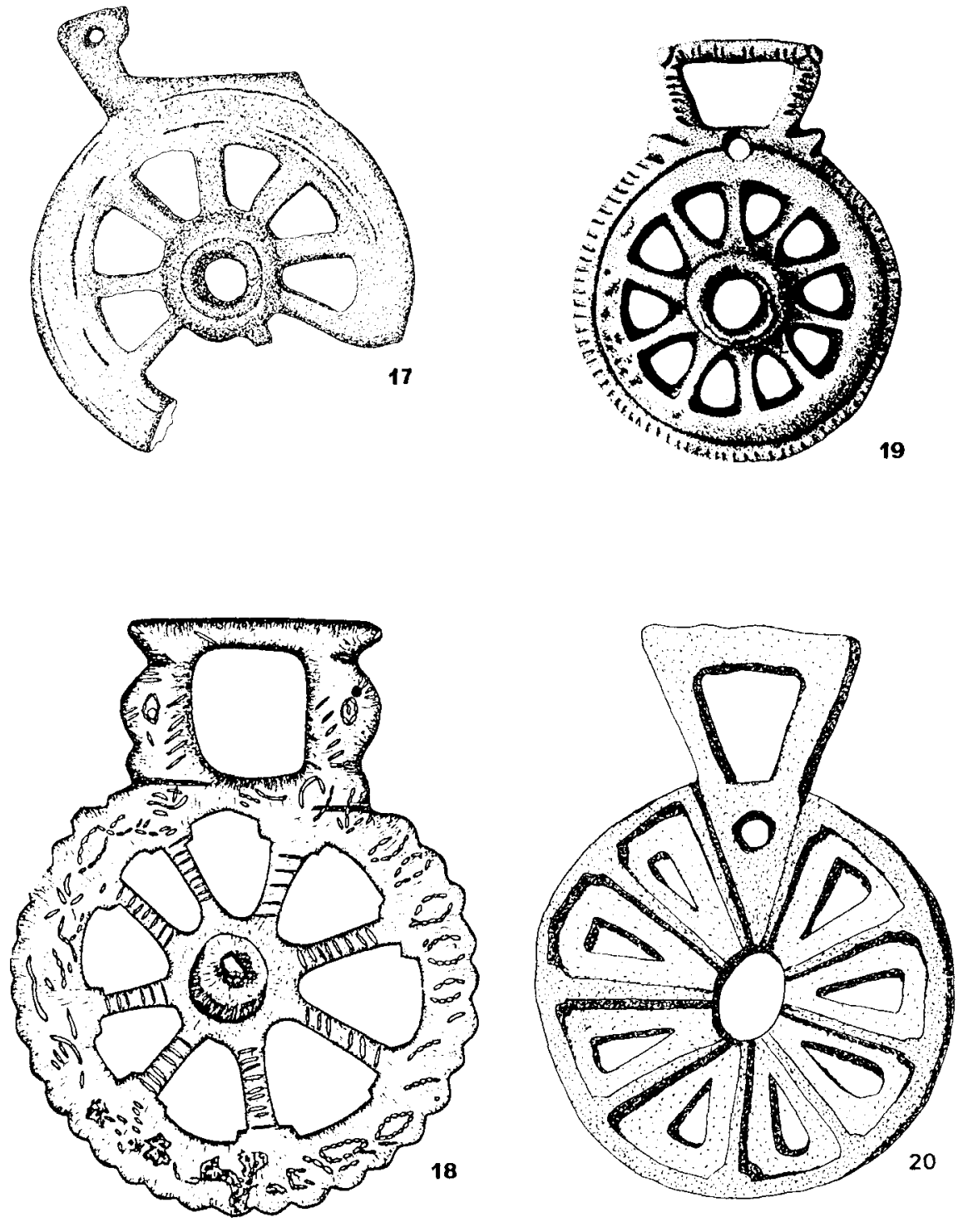

Fig. 9. Camas procedentes de: 17 y 20, procedencia desconocida; 18, El Algallarin; 19 , Conímbriga. 

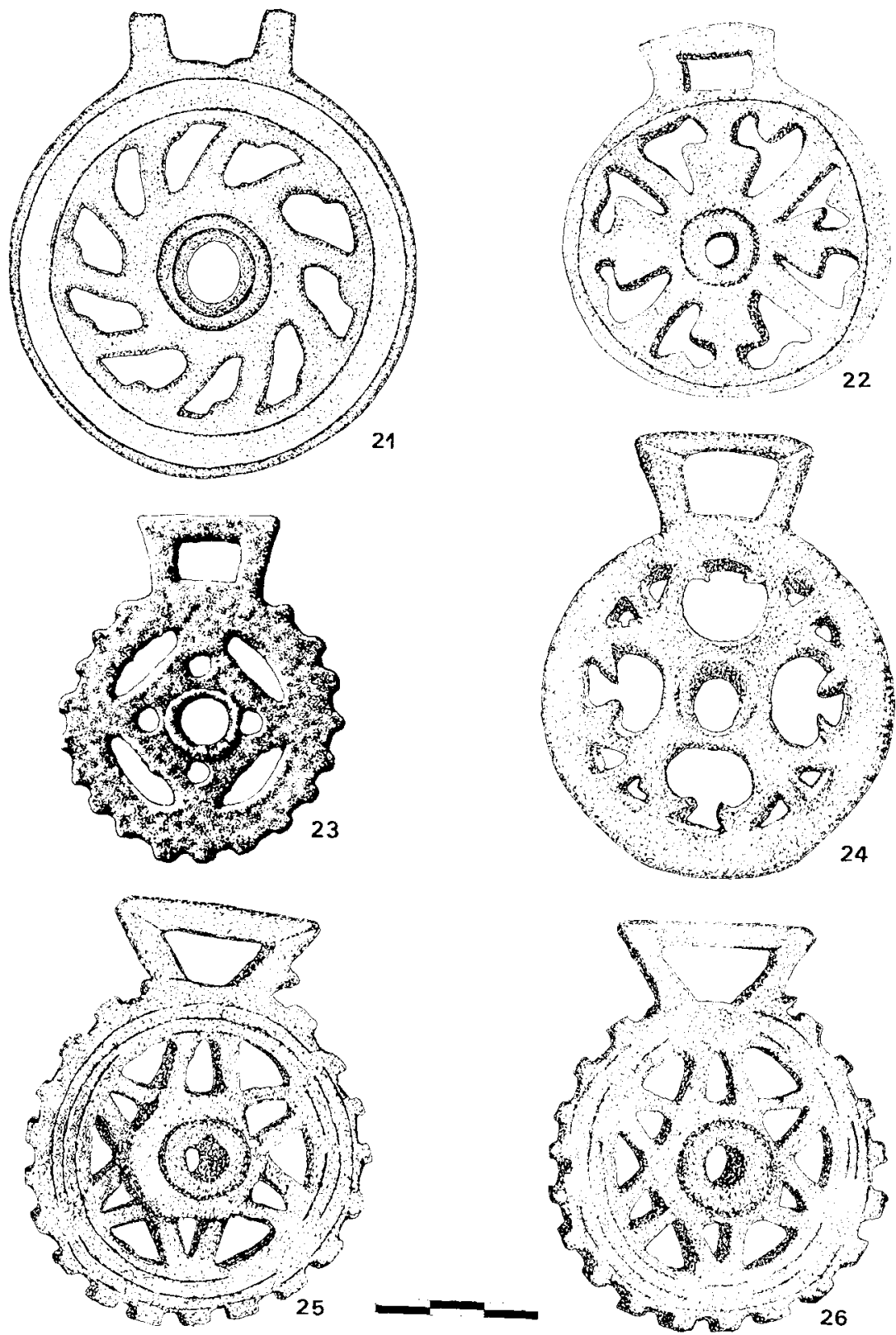

Fig. 10. Camas procedentes de: 21, procedencia desconocida; 22, Menorca; 23, provincia de Sevilla; 24, Vilauba; 25-26, Cubillas de Cerrato. 
40.- Procedencia desconocida ${ }^{68}$. MAN ( $n^{0}$ inv. 7458). Cama circular que presenta una decoración calada de dos anillos externos girando alrededor de un crismón. Las digitaciones son globulares y dejan espacios libres ligeramente elipsoidales. El perfil interno muestra también digitaciones sinusoidales. El paso de filete es moldurado. El enganche de montante es de forma rectangular con extremos sobresalientes. Dimensiones: $8^{\prime} 5 \mathrm{~cm}$, de diámetro.

41.- Provincia de Sevilla, lugar de hallazgo no determinado ${ }^{69}$. RGZM. Cama circular compuesta de un anillo cuyo perfil externo está ornamentado por catorce digitaciones globulares que enmarcan el espacio reservado al enganche de montante. Este último es de forma rectangular y con una pequeña fisura en la parte alta. La superficie del anverso del anillo externo está recorrida por una serie de circulos concéntricos unídos entre si por medio de una pequeña línea. La zona central de la cama está ocupada por un crismón de brazos potenzados. Un alpha se apoya entre los dos brazos de la izquierda y a la derecha se sitúa la omega libremente. Tanto estas dos letras como el crismón presentan una simple ornamentación de líneas y pequeños trazos paralelos. La perforación circular del paso de filete está circunscrita por una moldura con trazos de uso. El reverso ha sido pulido aunque presenta rebabas de fundición. Dimensiones: $9^{\prime} 1 \mathrm{~cm}$. de diámetro, 10'6 cm. de altura, $0^{\prime} 4 \mathrm{~cm}$. de espesor y 149'420 gr. de peso.

42.- El Monastil (Elda, Alicante) ${ }^{70}$. Museo Arqueológico de Elda (Alicante). Fragmento de cama circular. Corresponde a la parte superior de la cama, observándose el inicio del crismón y uno de los brazos potenzados. El enganche de montante de forma rectangular presenta dos incisiones rectilíneas en los ángulos superiores. Dimensiones: $6^{\prime} 0 \mathrm{~cm}$. de diámetro.

\section{Camas con decoración geométrica e inscripción}

En este grupo de camas hemos incluido aquellas que presentan una decoración geométrica simple además de una inscripción. Esta última puede haber sido calada y sirve al mismo tiempo de ornamentación (tres ejemplares) o bien incisa (una pieza).

43.- Almazarrón (Cartagena, Murcia) ${ }^{71}$. Objeto actualmente perdido. No presentamos ni dibujo ni fotografia. Cama circular con perforación de paso de filete taponada por concreciones férreas y enganche de montante de forma cuadrada. La decoración calada se distribuia en dos registros y formaba una inscripción. Esta cama sólo puede ser estudiada a partir de la fotografía publicada por Hübner. Según este autor la lectura de la inscripción es la siguiente ${ }^{72}$ :

\section{SCE PAVLINE VIVAS ETEORIS / ET SEMPER SEDAS (ET FLOREAS).}

P. de Palol observa que la segunda línea, es desde su inicio, de dificil lectura -et semper sedas-, pero está de acuerdo en ver en esta frase una invocación religiosa: sce Pauline

68 PALOL 1952, p. 308, fig. 4. 18.

69 RIPOLL, L'archéologie funéraire de Bétique..., op. cit., p. 228, fig. 35.1, Lám. I, 1a y 1 b.

70 Agradecemos a A.M. POVEDA el habernos comunicado la existencia de esta pieza y el que nos haya proporcionado fotografías.

71 PALOL 1952, p. 305, fig. 3. 11.

72 A.E. HÜBNER, Incriptionum Hispaniae Christianarum, Supplementum, 89, n. 420. 
vivas eternis (?) et semper sedas et floreas in Deo ${ }^{73}$. Existe una diferencia en la lectura de ambos autores concerniente a la última palabra de la primera línea: eteoris para Hübner y eternis para Palol. Más tarde, éste último propuso sustituir eternis por et oris ${ }^{74}$. Por otra parte J. Vives propuso una tercera lectura de la primera línea: sce Pauline, vivas et floreas et semper sedas ${ }^{75}$. Este autor cree que et floreas puede corresponder a esta linea, pero tiene sus reservas dada la conservación de la pieza. También supone sedas por sedeas, refiriéndose para ello a la mención del nombre de Paulinus, como obispo de Eliocroca (Lorca). Debemos recordar que este nombre no se encuentra en las listas onomásticas de los obispos que firmaron las actas conciliares. Vives propone clasificar esta fórmula entre las aclamaciones que él denomina inter vivos ${ }^{76}$. Dimensiones: $12^{\prime} 0 \mathrm{~cm}$. de diámetro.

44.- Procedencia desconocida "7. Facultad de Filosofía y Letras de la Universidad de Santiago de Compostela (?). Cama circular cuyo perfil exterior está ornamentado con catorce digitaciones de forma ligeramente cuadrangular. El enganche de montante es también cuadrangular. En el centro, el orificio para el paso del filete se señala por medio de una moldura. Alrededor de éste gira hacia la derecha una inscripción calada:

EX OFICINA (signo de puntuación).

La primera lectura dada por P. de Palol fue: EX OFICINA I $^{78}$. Más tarde leyó: EX OFFICINA $I^{79}$. Esta última lectura no es satisfactoria pues la inscripción está constituída de diez signos, sobra una $F$ y el " $/$ " sólo tiene una función decorativa o es un signo de interpunción, indicando donde empieza y acaba la inscripción ${ }^{80}$. Cabe señalar que al principio de la inscripción las letras respetan unos espacios de distanciamiento que a medida que avanza se van dilatando cada vez más. El conjunto de letras presenta un suave ápice. La primera letra " $E$ " es poco legible y la última, la " $A$ ", ha perdido el trazo transversal. Dimensiones: $6^{\prime} 0 \mathrm{~cm}$. de diámetro y $8^{\prime} 0 \mathrm{~m}$. de altura.

45.- Pedrosa de la Vega (Palencia) ${ }^{81}$. Museo de Saldaña (Palencia). Hallazgo superficial no correspondiente a ningún nivel estratigráfico. Cama circular. El perfil externo está ornamentado con nueve digitaciones, con intervalos semicirculares, evocando motivos vegetales trilobulados - a modo de volutas - recorridos por una línea incisa que en los extremos forma pequeñas espirales. Unos pequeños triángulos indican la base de dichas digitaciones. La inscripción calada está rodeada de dos lineas paralelas y gira alrededor de la perforación del paso de filete que se presenta de forma muy robusta. La decoración epigráfica se inicia en el eje de simetría de la pieza y gira hacia la derecha. En ella se lee:

73 Palol 1952, p. 305.

74 P. de PALOL, Arqueología cristiana de la España romana, siglos $\mathrm{V}-\mathrm{V} /$, CSIC, Madrid-Valladolid, 1967, p. 356.

${ }_{75}$ J. VIVES, Inscripciones cristianas de la España romana y visigoda, CSIC, Monumenta Hispaniae Sacra, II, Barcelona, 1969, p. 137-138, n. 401.ç

${ }_{76}$ VIVES, Inscripciones cristianas..., op. cit., p. 279.

77 PALOL 1953-54, p. 282, fig. 2. a.

78 PALOL 1953-54, p. 282.

79 PALOL, Arqueologia cristiana..., op. cit., p. 356.

so Las puntuaciones pueden ser muy variadas. Véase por ejemplo la esquematización de la hedera de la cama de Tamuda con VIR BONE VIVAS, o la de Pedrosa de la Vega con ASTVRI VIVAS.

8) PALOL, La villa romana de la Olmeda..., op. cit., p. 62. PALOL y CORTÉS, La villa romana de Pedrosa..., op. cit., p. 95-98, fig. 24. 10. 
(signo de puntuación) ASTVRI VIVAS.

El signo de puntuación utilizado, que indica donde empieza y acaba la inscripción, es de forma trilobulada y sugiere una deformación de una hedera. Todas las letras pesentan un ápice en sus extremos y el distanciamiento entre ellas es ligeramente más amplio en la zona superior que en la inferior. En lo que al enganche de montante respecta, éste es de forma triangular con perforación cuadrangular, sus ángulos presentan unas pequeñas protuberancias que sugieren motivos vegetales (?) o animales (?). En realidad estas protuberancias del enganche podrian estar representando delfines, tal como ocurre en las camas $n^{\circ} 18,71$ y 73 . Tanto el enganche de montante como la perforación para el paso del filete presentan huellas de desgaste. Dimensiones: $11^{\prime} 3 \mathrm{~cm}$. de altura y $10^{\prime} 5 \mathrm{~cm}$. de diámetro.

46.- Mérida (Badajoz) ${ }^{82}$. MAN. Cama circular cuyo anillo externo está recorrido por una serie de digitaciones rectangulares que enmarcan el enganche de montante. La superficie del anillo está decorada en su parte derecha por una línea de círculos concéntricos y en su parte izquierda por una inscripción grabada y de difícil lectura. Ésta se lee a partir de la izquierda y de arriba a abajo:

\section{EX OFFICINA NECLEC $<L>T I$.}

Según P. de Palol la lectura seria: EX OFFICINA NECLECTI, sin descartar la posibilidad de que la segunda $N$ podria ser también $I N$ o $A N^{83}$. Sin embargo el espacio libre no es suficiente para situar dos letras. El mismo autor considera que la segunda y tercera $C$ podrían ser G: y que entre $L$ y $T$ l existía un punto de separación, pero aqui el espacio tampoco es suficiente. L. Vázquez de Parga propuso una lectura diferente: $A N E C L E<C L>T I$, considerando la segunda $C L$ como error y repetición de la primera debido a la existencia de una $E$, puesto que considera que $C L$ fonéticamente no puede estar seguido de $T^{84}$. Creemos que la lectura de $N E C L E C<L>T /$ es la más plausible, a pesar de la inserción de la consonante líquida $L$ entre dos sordas $C$ y $T$. Estamos muy probablemente ante el genitivo singular del nombre Neclectus, $-i$, (de neglectus, -a, -um, del verbo neglego), si admitimos que el verbo pudo dar lugar al nombre. Es frecuente el ensordecimiento de la $g$ en el latín tardio. La zona central de la cama está ocupada por una decoración geométrica de radios unidos en sus extremos por semicirculos y girando alrededor de la perforación central del paso de filete del cual se conservan restos férreos. Tanto los radios como los semicírculos presentan una ligera decoración de líneas paralelas incisas y círculos concéntricos. El enganche de montante es de forma rectangular. Dimensiones: $8^{\prime} 0 \mathrm{~cm}$. de diámetro.

\section{Camas con decoración zoomorfa: representaciones de un único caballo e inscripción}

Tan sólo dos camas pertenecen a este grupo. Ambas presentan en su decoración un caballo y una inscripción que muy probablemente hace referencia al nombre del équido.

82 PALOL 1952, p. 304, fig. 3. 8. Queremos agradecer aquí al Profesor Juan José Sayas las indicaciones sugeridas en las agradables y fructíferas charlas pasadas en la UNED de Madrid.

83 PALOL 1952 , p. 304.

84 L. VAzQUEz De PARGa, "Disco de bronce de arreo de caballo", Memorias de los Museos Arqueológicos, 1958 a 1961, Madrid, 1963, p. 35-36. 

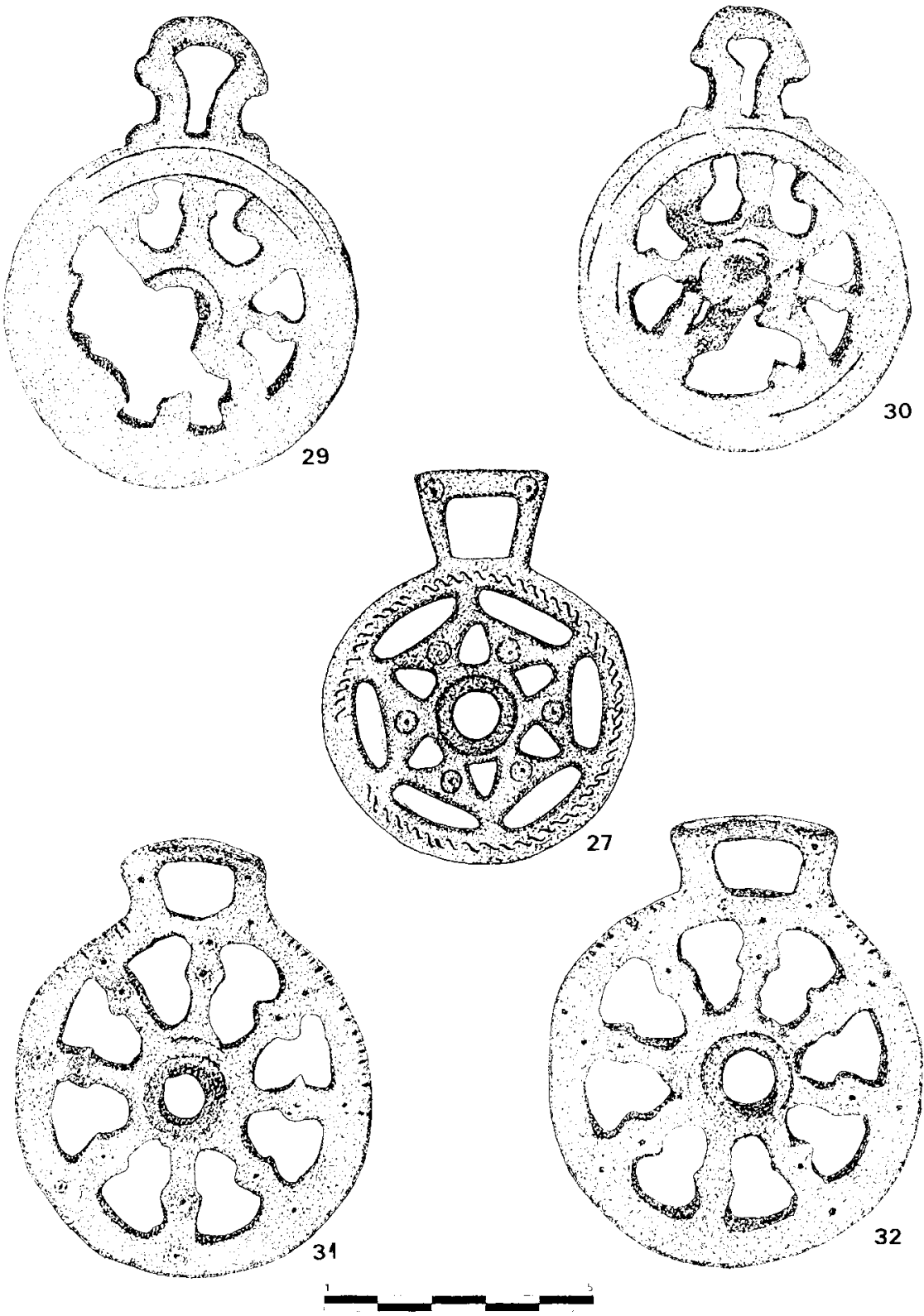

Fig. 11. Camas procedentes de: 27, provincia de Palencia; 29 a 32, Pollentia. 

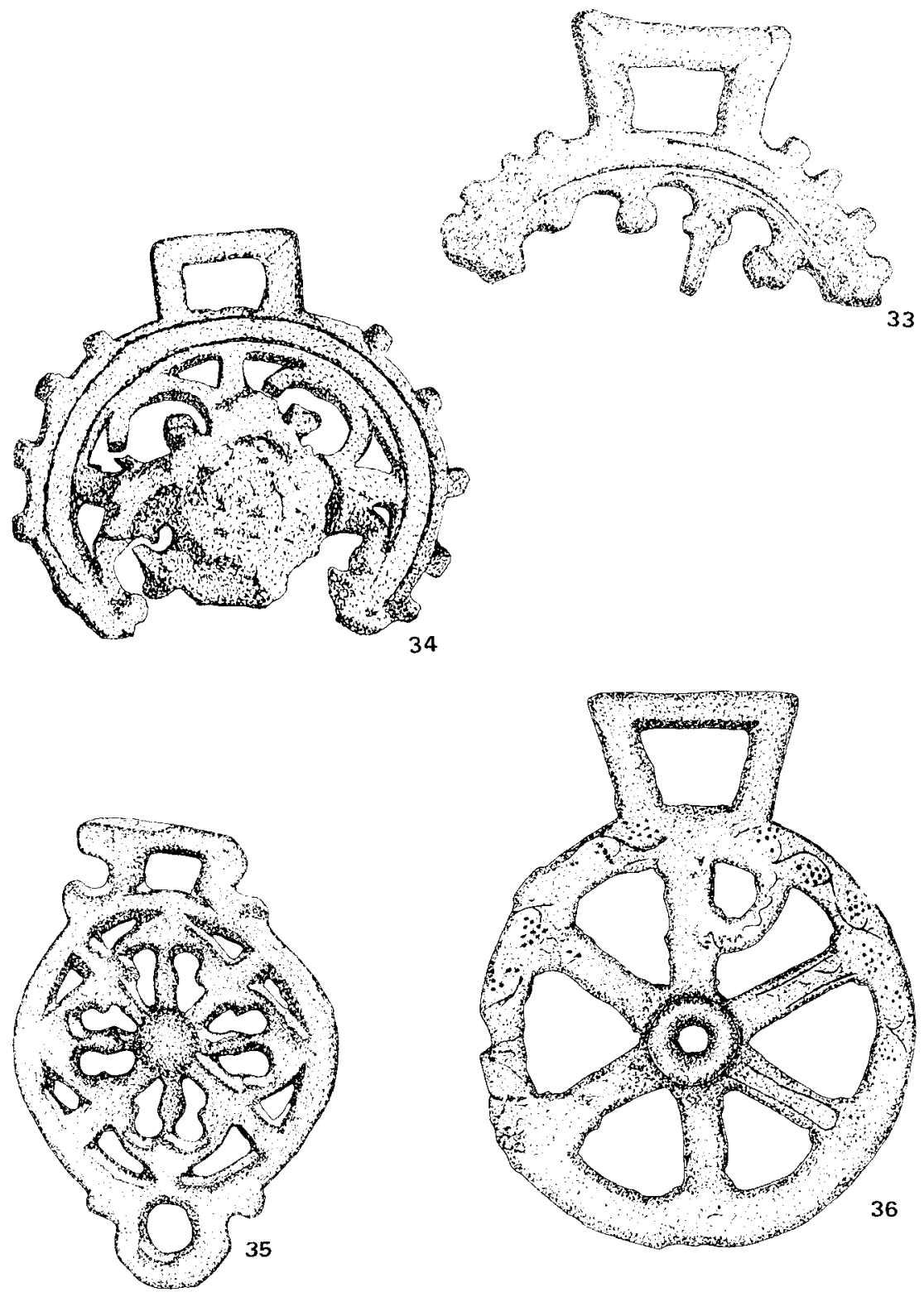

Fig. 12. Camas procedentes de: 33 a 35 , procedencia desconocida; 36 , provincia de Soria. 
47.- Clunia (?) (Burgos) ${ }^{85}$. IVDJ. De procedencia desconocida según P. de Palol ${ }^{86} \mathrm{y}$ hallada en Clunia según M. López Serrano ${ }^{87}$. Cama circular cuyo perfil exterior del anillo está ornamentado por medio de once digitaciones globulares con círculos concéntricos. En la superficie del anillo aparece una decoración incisa de una linea de escuadras superpuestas y partidas. Según P. de Palol ${ }^{88}$ estos trazos hacen referencia a las palmas agonísticas. La zona central de la cama está ocupada por una decoración calada. Se trata de un caballo visto de perfil y avanzando hacia la izquierda. Unas pequeñas incisiones remarcan la crín y dan un mayor volumen a la grupa. El ojo se indica por medio de un círculo concéntrico. La boca del caballo se señala por medio de una linea trazada a bisel que sine al mismo tiempo de montante y de testera. En el anca aparece la letra $A$ y en la espalda la letra $N$ al revés: $U$. Ambas letras hacen referencia seguramente a la cuadra a la que perteneció el caballo. En el cuello aparece una inscripción formada por cuatro caracteres griegos: $E \wedge Y X$. Según $P$. de Palol, la lectura correcta seria $(F) E \wedge Y X$ (Felix) ${ }^{89}$, sin embargo en un procedimiento fonético normal la primera letra puede alterarse 0 desaparecer, pero no puede ocurrir nunca cuando esta letra es una aspirada como en el caso de $F$, sólo una $H$ o una $G$ podrian suplir dicha aspiración. También podríamos aceptar que la $F$ se sitúa delante de la $E$, pero que se ha perdido, puesto que parece que si existen algunos trazos, imposibles hoy de leer. Podría tratarse también de una falsa interpretación del substantivo $\varepsilon \lambda \xi \xi$ puesto que la confusión de la xi final por la khi, asi como la sustitución de la upsilon por la iôta, es bastante frecuente. Si fuese así, este substantivo estaria definiendo el pelo de la crín del caballo que sería en forma de bucles. Pasando ya a la perforación circular para el paso del filete, ésta se halla ligeramente desplazada hacia la parte inferior. El enganche de montante es de forma rectangular. Unas pequeñas incisiones rectilineas y motivos de círculos concéntricos permitirian suponer que se trata de esquematizaciones de peces. Esta cama estuvo situada en la izquierda del freno del caballo. Dimensiones: $8^{\prime} 0 \mathrm{~cm}$. de diámetro y $9^{\prime} 5 \mathrm{~cm}$. de altura.

48.- Procedencia desconocida ${ }^{90}$. Colección Jules Sambon (Paris) (?). Cama circular cuyo anillo externo se halla provisto de una ornamentación basada en una línea sinuosa ondulante. La zona central está ocupada por una decoración calada dispuesta en dos registros separados por medio de una moldura rectilínea horizontal. En la parte superior se dispone un équido de perfil mirando hacia la derecha. La cabeza se apoya directamente sobre el anillo externo, al igual que parte de la cola. Tan sólo se hallan representadas tres patas y la anterior se apoya en una tabella rectangular donde parece que se leia la inscripción:

\section{TAGVS.}

Ni el nombre, ni el arnés, ni la silla (tan sólo esbozada), son visibles en los dibujos proporcionados por P. de Palol ${ }^{91}$, pero parece que no hay duda que existieron. La perforación

85 PaLol. 1952, p. 311-312, fig. 5. 22.

86 PALOL 1952, p. 312.

97 Matilde Lópz SeRrano, "Artes decorativas de la època visigoda. Adiciones», en Historia de España de Ramón Menéndez Pidal, vol. IIl: España visigoda, Madrid, 1963 (2ªd.), p. 814 y 817 , fig. 585 .

88 PALOL 1952, p. 311.

89 PALOL, Arqueología cristiana..., op. cit., p. 358.

90 PALOL 1952, p. 311, fig. 5. 21.

91 P. DE PALOL aclara que los dibujos de la cama de la Colección Jules Sambon son debidos a la amabilidad del Sr. Montenegro. 

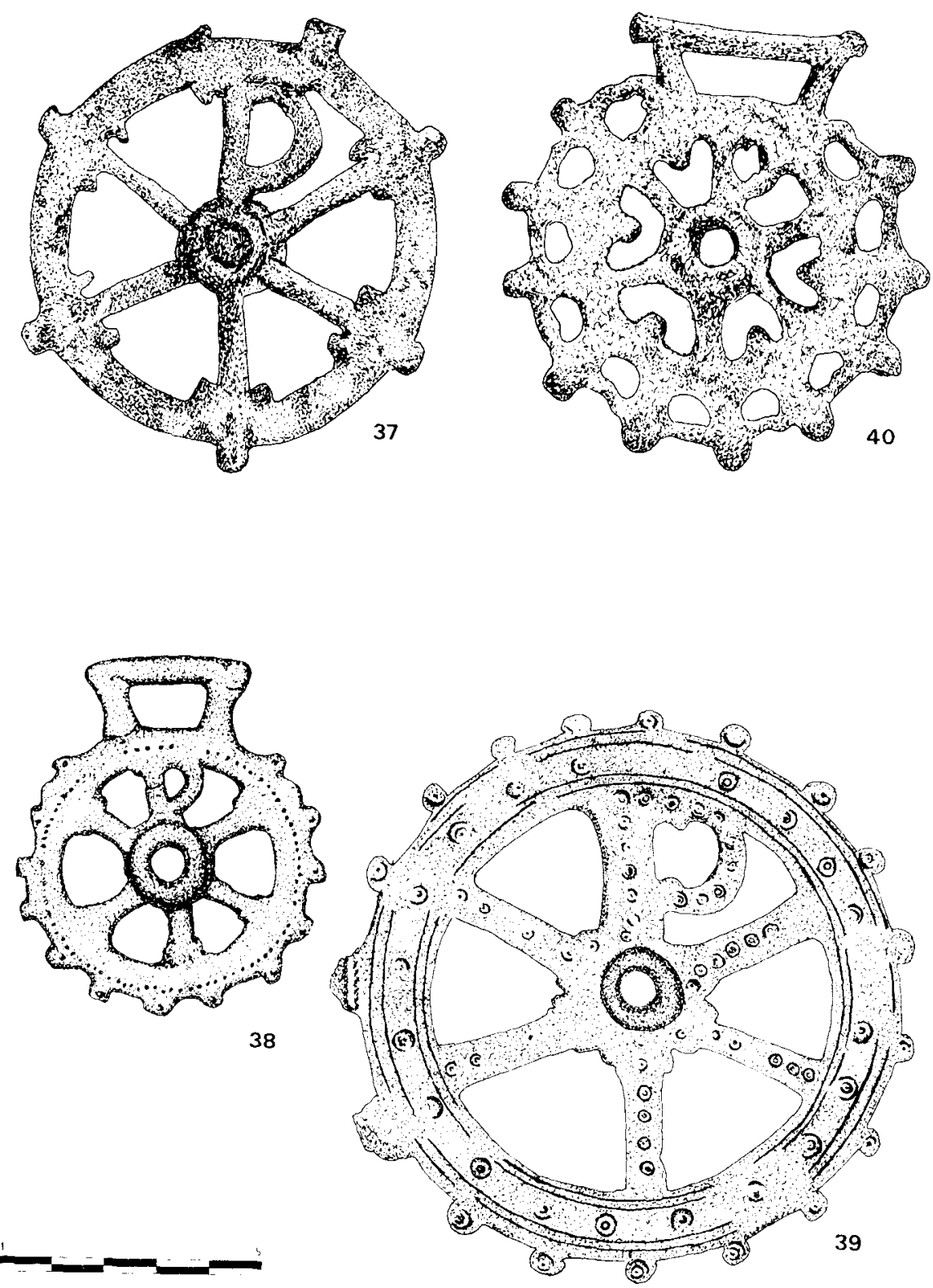

Fig. 13. Camas procedentes de: $37-38$ y 40, procedencia desconocida; 39, Muradela. 
circular para el paso de filete se sitúa en el registro inferior y está rodeada de motivos vegetales esquematizados y calados. El enganche de montante es de forma rectangular y los ángulos superiores presentan dos digitaciones globulares. Estuvo situado en la derecha del freno del caballo. Dimensiones desconocidas.

\section{Camas con decoración zoomorfa: representaciones de un único caballo}

El grupo de camas precedente se ve aumentado en cuatro piezas más, pero éstas no llevan ninguna inscripción y por ello creemos conveniente estudiarlas separadamente. Estas camas se caracterizan por la representación de un único caballo, que mira hacia la izquierda o la derecha dependiendo de su posición en el freno.

49.- Santa Elena (Jaén) ${ }^{92}$. Museo de Linares (Jaén). Cama circular con anillo externo ornamentado con once pequeñas digitaciones en el perfil y la superficie con motivos de círculos concéntricos. La zona central de la cama se divide en dos registros por medio de una moldura rectilínea dispuesta horizontalmente. En el registro superior se encuentra un caballo de perfil mirando a la derecha. El caballo representado no está enjaezado y está en posición de marcha, doblando ligeramente la pata anterior derecha. La cabeza, la cola y la grupa se apoyan directamente sobre el anillo externo. En el registro inferior se sitúa la perforación para el paso del filete. El enganche de montante es de forma rectangular. Formaba parte del mismo freno que la $n^{\circ} 50$, y estaba situado en la parte izquierda de éste. Dimensiones: $8^{\prime} 6$ $\mathrm{cm}$. de diámetro y $10^{\prime} 0 \mathrm{~cm}$. de altura.

50.- Santa Elena (Jaén) ${ }^{93}$. Instituto de Estudios Gienenses (Jaén). Cama circular prácticamente identica a la anterior $\left(n^{\circ} 49\right)$. No proceden del mismo molde a no ser que hubiesen sido retocadas posteriormente, puesto que las digitaciones no presentan el mismo distanciamiento, la moldura que divide los dos registros no se encuentra en el mismo lugar y la representación del caballo es ligeramente diferente. El équido visto de perfil mira hacia la izquierda. La pata anterior derecha ligeramente levantada. La cola se apoya, al igual que la cabeza, sobre el anillo. Tal como podemos apreciar por la postura de los caballos de las camas $\left(n^{\circ} 49\right.$ y 50$)$, parece que se trata del mismo animal visto por ambos lados. Sobre el enganche de montante aparece una linea incisa. Estuvo situada en la parte derecha del freno. Dimensiones: $8^{\prime} 6 \mathrm{~cm}$. de diámetro y $10^{\prime} 0 \mathrm{~cm}$. de altura.

51.- Monturque (Córdoba) ${ }^{94}$. Museo Arqueológico de Córdoba ( $n^{\circ}$ inv. 11.311). Cama circular cuyo anillo externo está ornamentado con una línea incisa de triángulos alternando puntos, parcialmente perdidos en la parte inferior derecha. La zona central de la cama está ocupada por la representación de un caballo visto de perfil y mirando hacia la derecha. El équido se halla enjaezado y ensillado, y en posición de marcha pues levanta la pata anterior

92 P. DE PALOL, “Dos piezas de arnés con representaciones de caballos", Oretania, 5, 1960, p. 217 228, 7 fig.

93 PALOL, “Dos piezas de arnés con representaciones de caballos", op. cit., p. 217-228, 7 fig.

94 PALOL 1953-54, p. 282, fig. 4. b. S. DE LOS SANTOS, "La falera de Monturque (Córdoba)", Boletin de la Real Academia de Cordoba de Ciencias, Bellas Artes y Nobles Artes, 70, 1954, p. 165-168, fig. 9-12. MARcos Pous y Vicent, "Dos camas de freno de caballo...", op. cit., p. 25-32. 

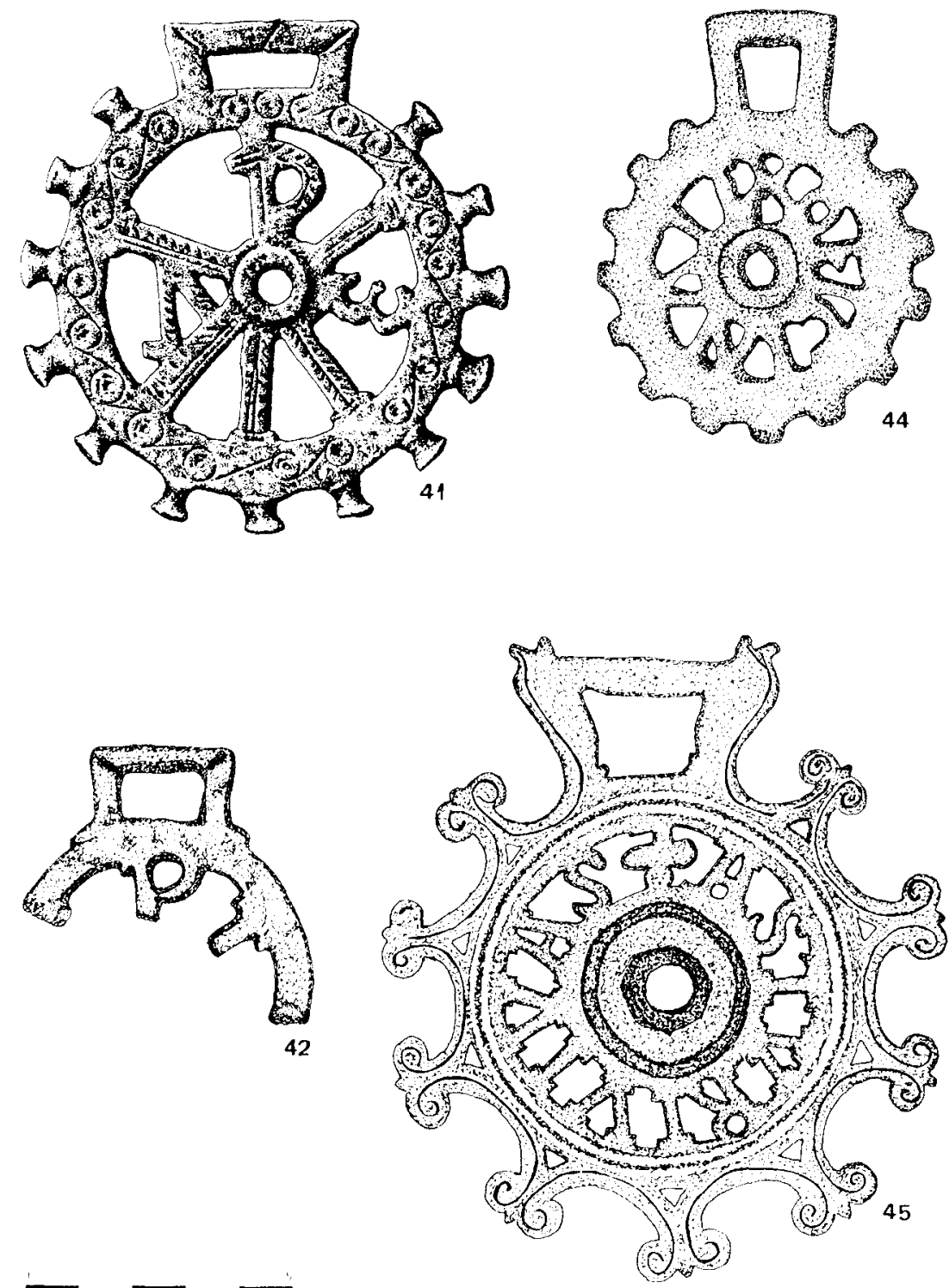

Fig. 14. Camas procedentes de: 41 , provincia de Sevilla; 42, El Monastil; 44, procedencia desconocida; 45 , Pedrosa de la Vega. 
derecha. La cabeza se apoya y sobrepasa la superficie del anillo externo. El caballo y la cama propiamente dicha, fueron fundidos separadamente. Posteriormente se retocaron a lima y se soldaron las dos piezas. En cuanto a la perforación circular para el paso del filete, ésta se sitúa en la parte inferior de la cama, entre las patas posteriores y anteriores del cabaIlo. El enganche de montante, de forma casi rectangular, debió estar decorado por medio de unos motivos similares a los del anillo externo, hoy prácticamente perdidos. Por la posición del caballo, esta cama se situaba a la izquierda del freno. Dimensiones: $7^{\prime} 2 \mathrm{~cm}$. de diámetro y $9^{\prime} 4 \mathrm{~cm}$. de altura.

52.- Clunia (Burgos) ${ }^{95}$. Museo Arqueológico de Burgos. Cama compuesta de un elemento decorativo exento que representa un caballo de perfil marchando hacia la derecha, con una pata anterior flexionada y larga cola. Apoyándose sobre la crín y la espalda, un motivo vegetal esquematizado (basado en grandes hojas) enmarca el enganche de montante de forma triangular. Bajo el vientre y entre las patas anteriores y posteriores, se sitúa el orificio circular para el paso de filete. Las patas del caballo se apoyan sobre una serie de motivos de dificil identificación pero que parecen corresponder a esquematizaciones vegetales. Por la posición del caballo, podria tratarse de la cama situada a la izquierda del freno. Dimensiones: $9^{\prime} 0 \mathrm{~cm}$. de altura.

\section{Camas con decoración zoomorfa: representaciones de caballos afrontados}

Dentro de este grupo encontramos por el momento una única cama. Se trata de una pieza inédita procedente probablemente de Hispania, conocida —desgraciadamente- a través del mercado de antigüedades. Es un ejemplar excepcional por su decoración y factura.

53.- Procedencia desconocida ${ }^{96}$. Ariadne Galleries (Nueva York, USA). Cama circular. La superficie del anillo externo está decorado con unas líneas sinuosas ondulantes imitando motivos vegetales. La zona central está ocupada por una ornamentación organizada en dos registros gracias a una moldura dispuesta horizontalmente y remarcada por medio de una línea de escuadras partidas. En el registro superior aparecen dos caballos afrontados a una palmera esquematizada. Los dos caballos levantan una de las patas anteriores. La crín está provista de una palma. En la grupa se lee con dificultad un signo circular (una hedera o una forma circular mal definida) correspondiente a la marca de la cuadra. El registro inferior está ocupado por la perforación circular para el paso del filete, alrededor de la cual giran dos motivos vegetales únicamente insinuados. El enganche de montante es de forma trapezoidal. Las dimensiones son desconocidas pero parecen responder a un diámetro de unos 8'5 cm.

95 PALOL 1952, p. 312, fig. 5. 23.

96 Esta nueva cama fue propuesta a compra al British Museum de Londres, pero pasó por fin a las colecciones de un anticuario de Nueva York, que nos envió la documentación y la publicación de su catálogo: Torkom DemirJian (ed.), Treasures of the Dark Ages in Europe, Ariadne Galleries, Nueva York, 1991, p. 136-137. 

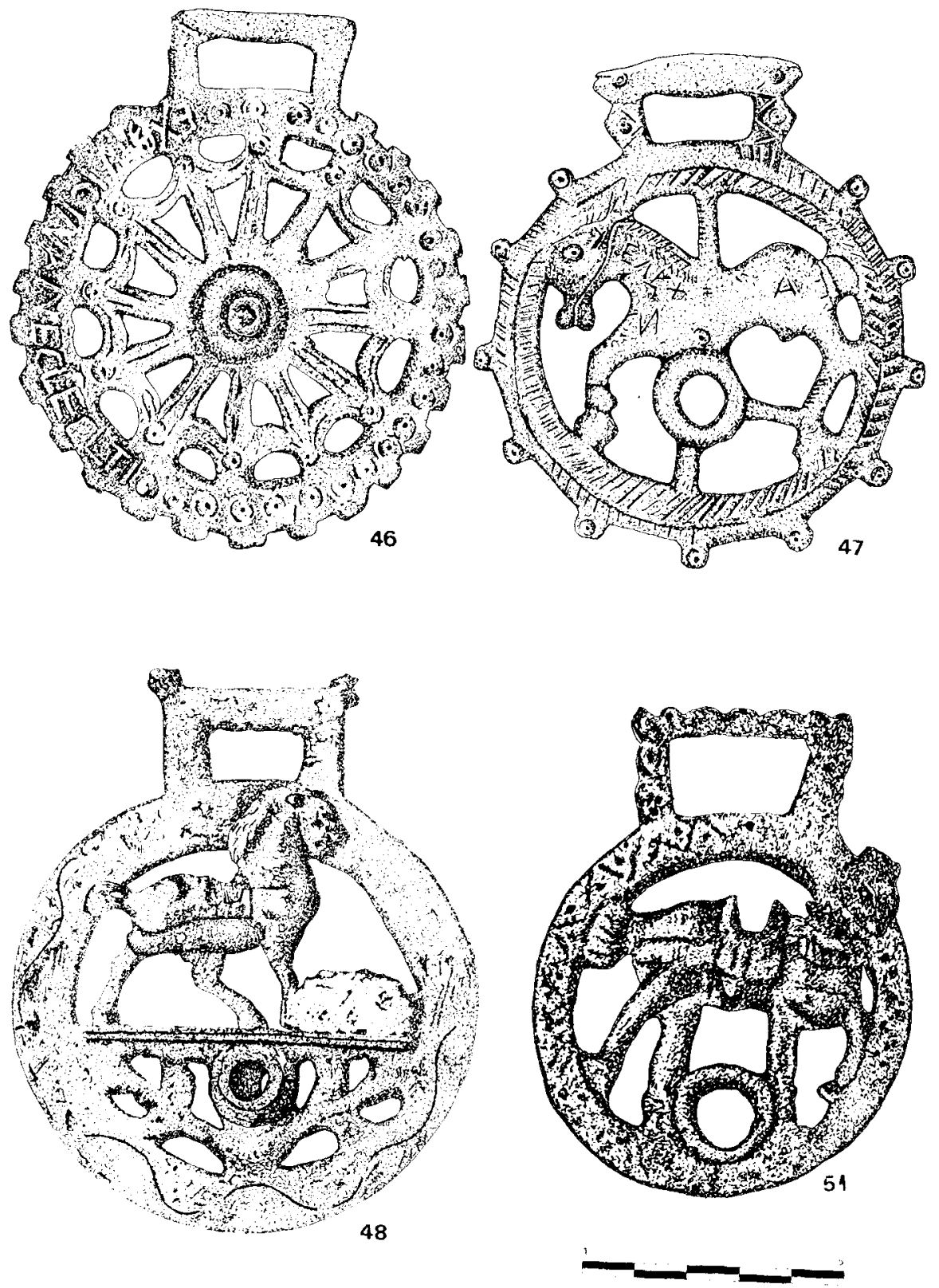

Fig. 15. Camas procedentes: 46 , Mérida; 47 , Clunia; 48 , procedencia desconocida; 51 , Monturque. 


\section{Camas con decoración zoomorfa: representaciones de caballos y delfines}

Dentro de este grupo contamos, por el momento, con un total de cinco piezas. Cuatro de ellas representan cuerpos y cabezas de delfines, siendo sustituida la cola de estos animales por cabezas de caballos. La caracteristica general de estas piezas es que los animales se distribuyen simétricamente a ambos lados del eje central de la cama, en posición heráldica. La $n^{\circ} 58$, hallada en Pedrosa de la Vega, presenta sólo los cuerpos de delfines. No sabemos si estamos ante la evolución del motivo decorativo precedente, o bien si se encuentra en el origen de éste, aunque bien podria tratarse de una representación que formase un grupo diferente.

54.- Procedencia desconocida ${ }^{97}$. Museo Lázaro Galdiano (Madrid) ( ${ }^{\circ}$ inv. 1.179). Cama con decoración exenta. Dos animales, vistos de perfil, se distribuyen a ambos lados del eje. Se trata de hibridos de caballo y delfín. En la parte superior de la cama aparecen los prótomos de los caballos, uno mirando hacia la derecha y el otro a la izquierda, enmarcando a la vez el enganche de montante de forma triangular. En la parte inferior los cuerpos de los caballos se convierten en cabezas de delfines muy esquematizadas. Estos apoyan sus hocicos en la perforación del paso de filete. Dimensiones: 7' $6 \mathrm{~cm}$. de altura.

55.- Cástulo (Jaén) ${ }^{98}$. Cama hallada en un nivel estratigráfico posterior al siglo Ill d.C., aunque no se determina a qué momento pertenece entre la segunda mitad del siglo IV y el siglo VII. La cama presenta una decoración exenta basada en dos cuerpos de animales con cabezas en sus extremos y vistos de perfil. La de la parte superior perteneciente a un caballo y la de la parte inferior, sin lugar a dudas, a un delfín. El cuello y larga crín de ambos caballos enmarcan el enganche de montante en cuyas asas aparece un pequeño vástago semicircular. La perforación del paso de filete se sitúa entre los hocicos de los dos delfines. Dimensiones: $8^{\prime} 4 \mathrm{~cm}$. de altura.

56.- Procedencia desconocida ${ }^{99}$. Ariadne Galleries (Nueva York, USA). Cama con decoración exenta. Dos cuerpos de animal en posición heráldica, se componen de prótomos de équidos en la parte superior y cabezas de delfines en la inferior, vistos de perfil. Los ojos, la crin y la boca de los caballos muy remarcados, al igual que los ojos y las aletas de los delfines. El enganche de montante de forma casi cuadrangular presenta en los ángulos del vástago horizontal una doble hoja, además de una decoración incisa de líneas sinuosas. Podría pertenecer al mismo freno que la $n^{\circ} 57$ e incluso proceder del mismo molde de fabricación. Las dimensiones son desconocidas pero parece responden a unos $8^{\prime} 5 \mathrm{~cm}$. de altura.

57.- Procedencia desconocida. Ariadne Galleries (Nueva York, USA). Cama igual a la anterior, aunque la decoración está ligeramente perdida debido al uso. Podría pertenecer al mismo freno y quizás al mismo molde que la $n^{\circ} 56$.

97 Palol 1952, p. 313, fig. 6. 24. Lopez Serrano, "Artes decorativas de la época visigoda. Adiciones", op. cit., p. 817, fig. 589.

98 J. M ${ }^{\mathrm{a}}$ BLAzouez et alii, Cástulo IV, E.A.E., 131, 1984, p. 50-51, fig. 22. 76, lám. XXX. 2.

99 Las camas $n^{\circ} 56$ y 57 , a igual que la mencionada anteriormente $n^{\circ} 53$, fueron compradas por Ariadne Galleries en Nueva York y publicadas en su catálogo: DEMIRJIAN (ed.), Treasures of the Dark Ages in Europe, op. cit., p. 136. 

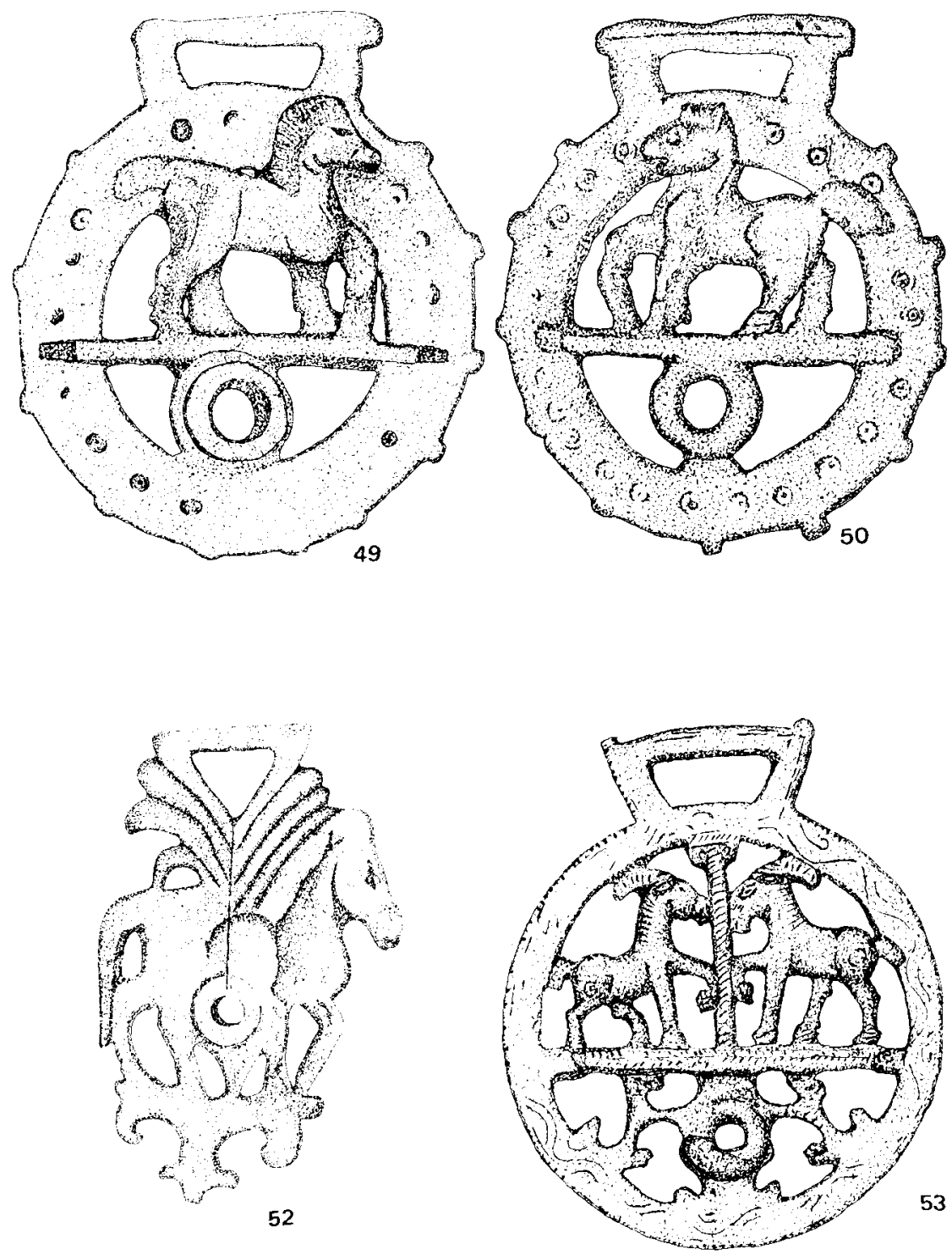

Fig. 16. Camas procedentes de: 49-50, Santa Elena; 52, Clunia; 53, procedencia desconocida. 

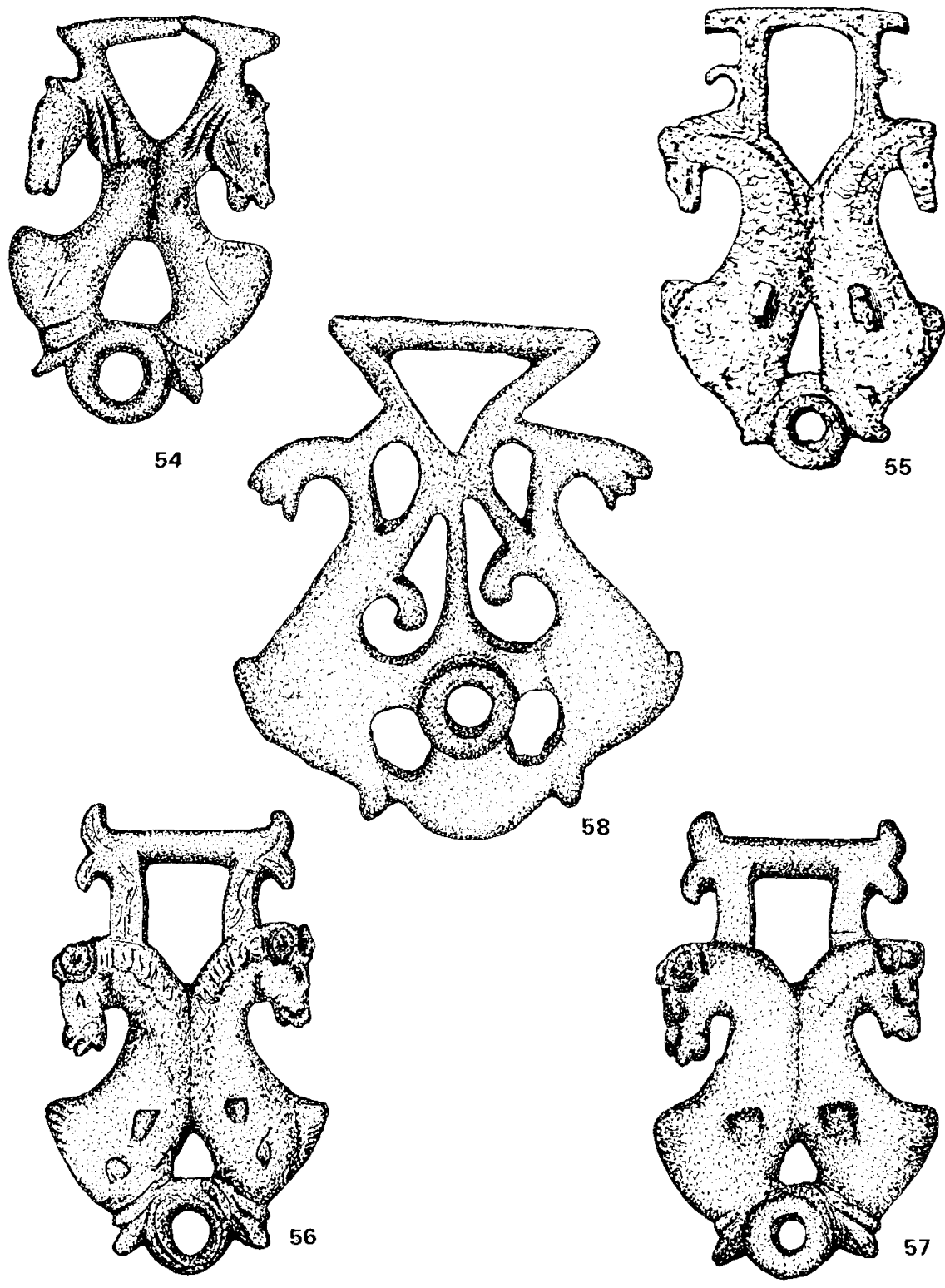

Fig. 17. Camas procedentes de: 54,56 y 57 , procedencia desconocida; 55 , Cástulo; 58 , Pedrosa de la Vega. 
58.- Pedrosa de la Vega (Saldaña, Palencia) ${ }^{100}$. Museo de Saldaña (Palencia). Cama con decoración animal exenta aunque la superficie del anverso no presenta ninguna ornamentación incisa. Los dos animales, delfines, en posición heráldica y vistos de perfil, apoyan su hocico en la perforación circular para el paso del filete y, al mismo tiempo, en una media luna, que podria tratarse de una concha. La cola de ambos delfines enmarca el enganche de montante que adopta una forma triangular. Dimensiones desconocidas.

\section{Camas con decoración zoomorfa: representaciones de felinos}

El grupo de camas con representaciones de felinos en posición heráldica, está constituido por once ejemplares. Todos ellos responden a unas mismas características morfológicas y ornamentales tratándose de felinos afrontados con las cabezas vueltas. Existen tres excepciones dadas por los hallazgos de Conimbriga ( $n^{\circ} 65,67$ y 68 ).

59.- Elche (?) (Murcia) ${ }^{101}$. MAN. Cama con doble decoración animal exenta. Se trata de dos felinos - panteras- vistos de perfil, con las cabezas vueltas a izquierda y derecha. Pequeñas incisiones indican el pelaje de los animales. La larga cola gira sobre si misma. La perforación para el paso del filete se enmarca por dos motivos vegetales y por las patas. El enganche de montante es de forma triangular. Dimensiones: $9^{\prime} 8 \mathrm{~cm}$. de altura y $8^{\prime} 3 \mathrm{~cm}$. de anchura.

60.- Procedencia desconocida ${ }^{102}$. Museo Lázaro Galdiano (Madrid) ( $n^{\circ}$ inv. 1.180). Cama con doble decoración animal exenta. Se trata de dos felinos -panteras- vistos de perfil y con las cabezas vueltas a izquierda y derecha. El pelaje del cuello está muy marcado, al igual que la larga cola que gira sobre si misma. Las patas de los animales se apoyan sobre la perforación del paso de filete. El enganche de montante, de forma casi triangular, viene determinado por la posición de las cabezas de ambos felinos. Dimensiones: $9^{\prime} 2 \mathrm{~cm}$. de altura.

61.- Elche (Murcia) ${ }^{103}$. Walters Art Gallery (Baltimore, USA). Cama con decoración de dos felinos - afrontados - vistos de perfil y con las cabezas vueltas a izquierda y derecha. El pelaje del cuello y del lomo están muy remarcados. Las patas de ambos animales se apoyan en el lugar fracturado donde se disponía la perforación del paso de filete, hoy perdida. El enganche de montante viene determinado por la disposición de las cabezas de los animales. Donde éstas finalizan se disponen dos pequeños vástagos que podrian referirse a esquematizaciones vegetales. Dimensiones: $7^{\prime} 4 \mathrm{~cm}$. de anchura y $9^{\prime} 0 \mathrm{~cm}$. de altura.

62.- Procedencia desconocida ${ }^{104}$. Metropolitan Museum (Nueva York, USA) ( $n^{\circ}$ inv. 199056). Cama igual a la precedente, $n^{\circ} 61$, exceptuando algunas diferencias que se refieren par-

100 PaLOL, La villa romana de la Olmeda..., op. cit., p. 51.

10 PaLOL $1953-54$, p. 284 y 286 , fig. 5 . c.

102 Palol 1952, p. 314, fig. 6, 26.

103 PALOL 1953-54, p. 286, fig. 5. a. b.

104 Agradecemos vivamente a Katherine Reynolds Brown, Conservadora en el Metropolitan Museum of Art de Nueva York, el habernos notificado la existencia de esta pieza y proporcionado toda la documentación. Una primera nota en: Katherine REYNOLDS Brown, "Harness Pendant", The Metropolitan Museum of Art Bulletin, 1990, p. 17. Posteriomente en: Id., "Hamess pendant or terminal for a bit", The art of medieval Spain, a.d. 500-1200, The Metropolitan Museum of Art, Nueva York, 1993, p. 69. 

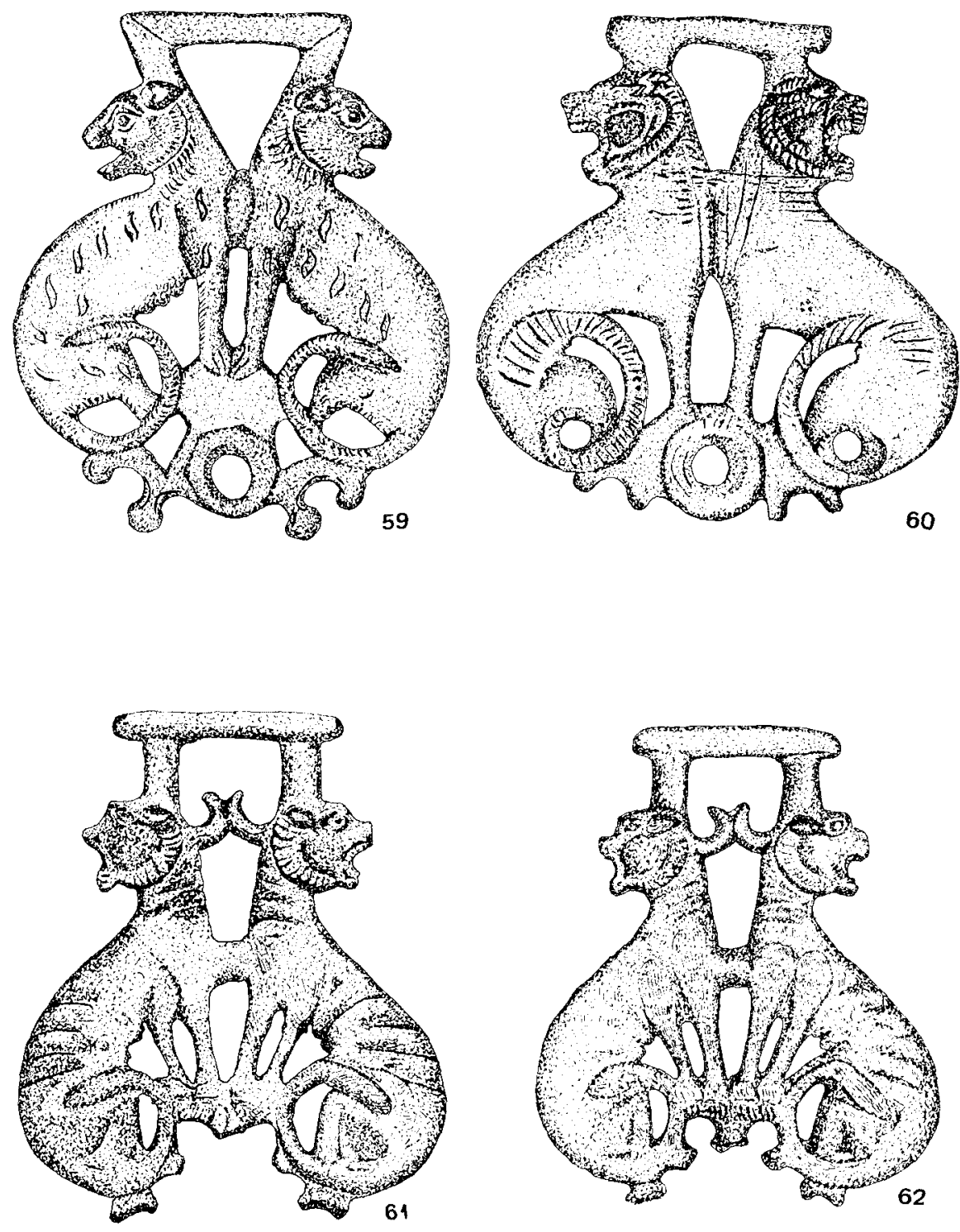

Fig. 18. Camas procedentes de: 59 y 61, Elche; 60 y 62, procedencia desconocida. 
ticularmente al pelaje del cuello y del lomo. La fractura se sitúa aproximadamente en el mismo lugar de la perforación que en la pieza anterior. Dimensiones: $8^{\prime} 9 \mathrm{~cm}$. de altura.

63.- La Torre (Ávila) ${ }^{105}$. Museo Provincial de Ávila. Cama con decoración exenta de dos felinos afrontados y vistos de perfil. Los dos animales - panteras- vuelven la cabeza, uno hacia la izquierda, el otro hacia la derecha. El pelaje del cuello está muy trabajado. Bajo el lomo liso aparecen las ubres, en número de tres. La cola recogida sobre la pata posterior. Las pezuñas de ambos animales se apoyan sobre la perforación circular del paso de filete. Entre las cabezas de los animales se situan dos pequeños vástagos de tipo vegetal. El enganche de montante viene determinado por la disposición de las cabezas de los felinos y se prolonga, sobresaliendo, el vástago transversal. Dimensiones: $8^{\prime} 3 \mathrm{~cm}$. de anchura y 10 $\mathrm{cm}$. de altura.

64.- Procedencia desconocida ${ }^{106}$. Museo Lázaro Galdiano (Madrid) ( $n^{\circ}$ inv. 1.182). Cama con decoración de dos animales. La pieza fracturada al nivel del cuello del animal izquierdo, está muy desgastada, hecho que dificulta su lectura. Muy probablemente se trate de felinos (panteras ?), que al igual que el resto de la serie están afrontados y volviendo la cabeza, uno a la derecha y el otro a la izquierda. Las patas anteriores y posteriores se reunen alrededor de la perforación circular para el paso del filete. El enganche de montante fracturado y perdido. Dimensiones: 8 '1 $\mathrm{cm}$. de altura.

65.- Conímbriga (Portugal) ${ }^{107}$. Museo Monográfico de Conímbriga ( $\mathrm{n}^{\circ}$ inv. A.309). Hallado en las excavaciones anteriores a 1962, en el ángulo N-E de las termas. Cama con decoración exenta. Dos felinos, probablemente panteras, están en posición rampante y afrontados a un cántaro dispuesto en el eje central de la pieza. Las dos partes de las que se compone el cántaro están ornamentadas con grandes líneas verticales trazadas a bisel. En las asas, que son en realidad las patas anteriores de los animales, aparece un puntilleado. Tanto la cabeza como el pelaje del cuerpo de los felinos se remarca por medio de pequeños trazos, que a la vez le dan volumen. Las patas posteriores y la base del cántaro de apoyan sobre una superficie plana puntilleada que delimita la zona del paso de filete. Éste último es circular con una pequeña digitación en el vértice inferior. El enganche de montante es de forma rectangular con una línea de puntilleado y otra exterior de triángulos yuxtapuestos. Dimensiones: $10^{\prime} 7 \mathrm{~cm}$. de altura y $8^{\prime} 5 \mathrm{~cm}$. de anchura.

66.- Procedencia desconocida ${ }^{108}$. MAB. Cama con decoración exenta. Esta ornamentación está basada en dos felinos -leones- rampantes y afrontados. Ambos vuelven la cabeza, uno hacia la izquierda, el otro hacia la derecha. El pelaje del cuello adquiere mayor volumen que el resto. Las patas anteriores, entrecruzadas, se apoyan sobre un motivo vegetal trifoliado. Entre ambos aparece también una hoja. El trifolio y las patas posteriores se apoyan sobre una superficie plana donde se ubica la perforación circular para el paso de filete.

105 Se trata de un hallazgo casual, véase: E. PÉrez HerRero, "Cama de bocado tardorromano hallada en La Torre (Ávila)", Homenaje al Prof. Martin Almagro Basch, Madrid, 1983, vol. III, p. 429-438, lám. I, fig. 1.A.

${ }_{106}$ PALOL 1953-54, p. 291, fig. 5. d.

107 PereIRA, "Elementos de freios tardo-romanos...", op. cit., p. 14, fig. Il. 3.

108 PALOL 1953-54, p. 284, fig. 4. c. 

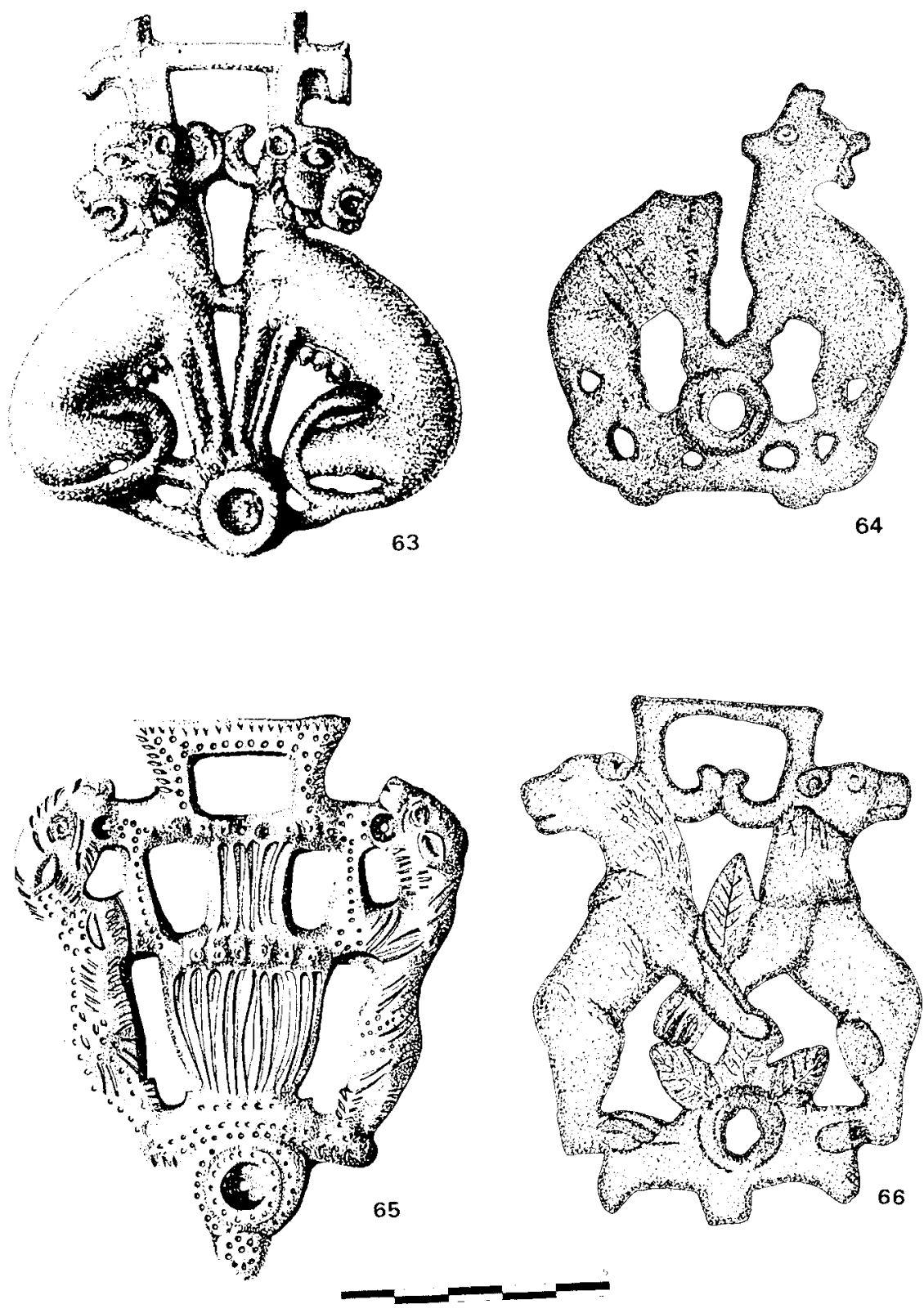

Fig. 19. Camas procedentes de: 63 , La Torre; 64 y 66 , procedencia desconocida; 65 , Conímbriga. 


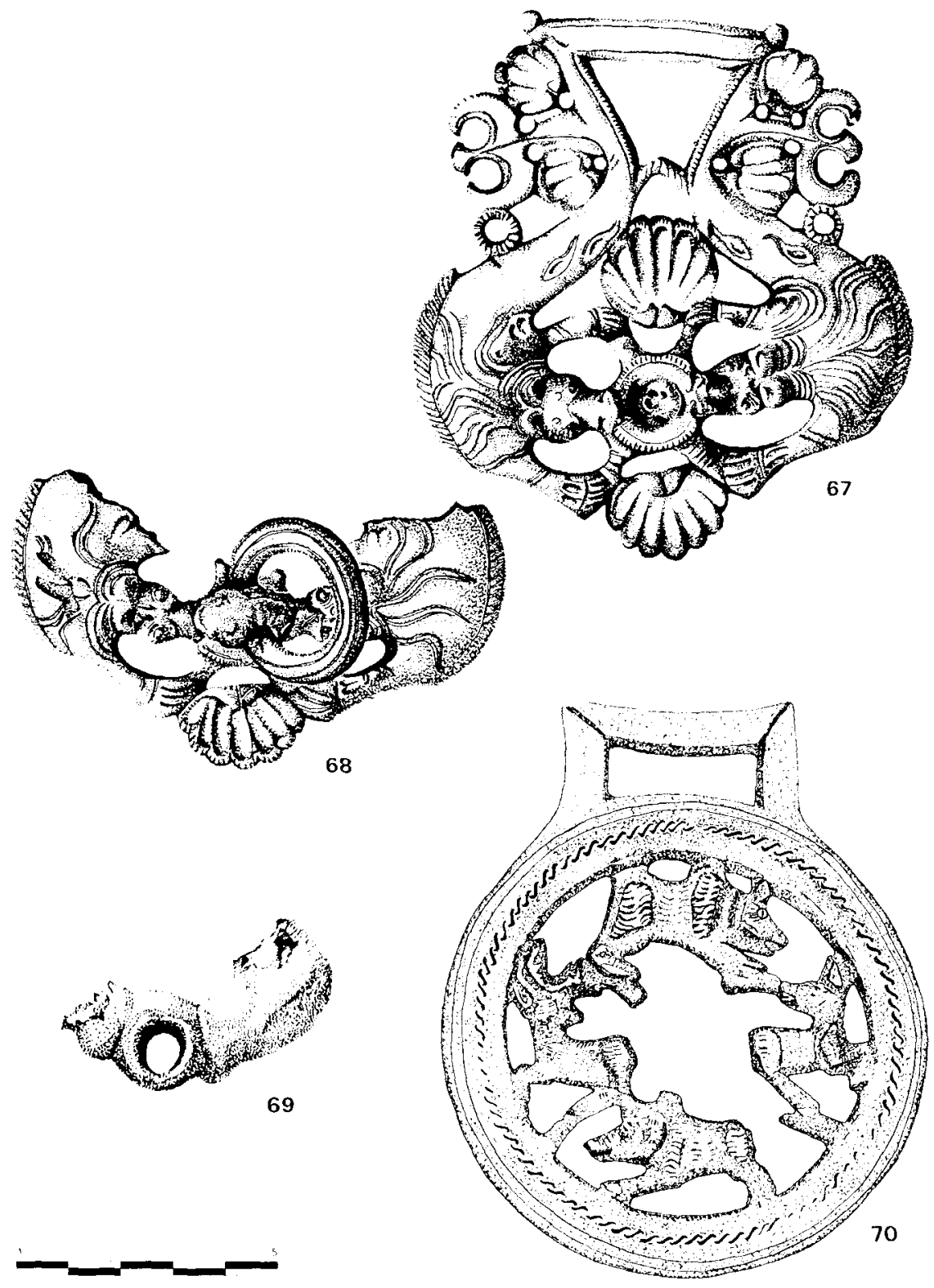

Fig. 20. Camas procedentes de: 67 a 69 , Conimbriga; 70, Burgos. 
El enganche de montante es de forma rectangular y viene determinada por la posición de las cabezas vueltas de ambos animales. El vástago inferior se cierra por medio de dos formas tipo voluta. Por las caracteristicas un poco hibridas de estos animales, a veces han sido considerados como osos. Dimensiones: $7^{\prime} 0 \mathrm{~cm}$ de anchura y $10^{\prime} 3 \mathrm{~cm}$. de altura.

67.- Conimbriga (Portugal) ${ }^{109}$. Museo Monográfico de Conimbriga ( $n^{\circ}$ inv. A.511). Hallazgo de las excavaciones anteriores a 1962. Pertenece probablemente al mismo freno que la $n^{\circ} 68$ y quizá haya sido fabricada con el mismo molde. Cama con decoración exenta. Dos animales híbridos se distribuyen simétricamente a ambos lados del eje central. Cada uno de ellos está constituido por una cabeza de largo pelaje, correspondiente a un felino león- $y$ una cola de animal marino en forma de tridente. El hocico de los animales y las patas anteriores se apoyan alrededor de la perforación circular para el paso de filete. En la zona inferior de la cama y entre los cuerpos de los dos felinos se sitúan dos uenerae. Éstas también se repiten a ambos lados de las colas. El enganche de montante se forma triangular viene determinado por la disposición de las colas. El paso de filete se halla taponado por restos férreos. Dimensiones: $10^{\prime} 2 \mathrm{~cm}$. de altura y $9^{\prime} 5 \mathrm{~cm}$. de anchura.

68.- Conimbriga (Portugal) ${ }^{110}$. Museo Monográfico de Conímbriga ( $n^{\circ}$ inv. A.512). Hallazgo de las excavaciones anteriores a 1962. Pertenece probablemente al mismo freno y quizás proviene del mismo molde que la $n^{\circ} 67$. Fragmento inferior de cama con decoración exenta, conserva el extremo del cañón y la anilla portarriendas. La decoración que se conserva corresponde a dos cabezas de felinos, prácticamente iguales a los de la $n^{\circ} 67$. Dimensiones: 9' $^{\prime} \mathrm{cm}$. de anchura y $5^{\prime} 5 \mathrm{~cm}$. de altura conservada.

69.- Conímbriga (Portugal) ${ }^{111}$. Museo Monográfico de Conímbriga ( ${ }^{\circ}$ inv. A. 913). Pequeño fragmento de cama, correspondiente a la zona de la perforación circular del paso de filete. Morfológicamente corresponde al mismo tipo que las $n^{\circ} 67$ y 68 , pero no se puede determinar si la decoración era semejante. Dimensiones conservadas: $4^{\prime} 0 \mathrm{~cm}$. de anchura.

\section{Camas con decoración de escenas: representación de uenationes}

Este conjunto de camas integra un total de tres piezas. Dos de ellas $\left(n^{\circ} 70\right.$ y 71$)$ presentan, probablemente, una uenatio de animales. La tercera cama $\left(n^{\circ} 72\right)$, presenta una escena con un jinete montando y cazando un cuadrúpedo (oso).

70.- Burgos (?) ${ }^{12}$. MAB. Cama circular. El anillo externo presenta una doble línea de trazo contínuo y otra de "s" inclinadas. La superficie central de la cama está ornamentada, gracias a un calado, con una escena de cuatro animales que se persiguen y que exentos giran alrededor del anillo. En el eje de simetría, se sitúan, corriendo hacia la derecha: un oso (en la parte superior), un perro que vuelve la cabeza hacia el oso (en el eje central derecho), un jabali (en la parte inferior) y por último un ciervo (en el eje central izquierdo). El pelaje del

109 PEREIRA, "Elementos de freios tardo-romanos...", op. cit., p. 14, fig. I. 1.

110 Pereir.4, "Elementos de freios tardo-romanos...", op. cit., p. 14, fig. I. 2.

111 PeREIRA, "Elementos de freios tardo-romanos...", op. cit., p. 14, fig. II. 4.

112 PALOL 1959, p. 329-330, fig. 1. 

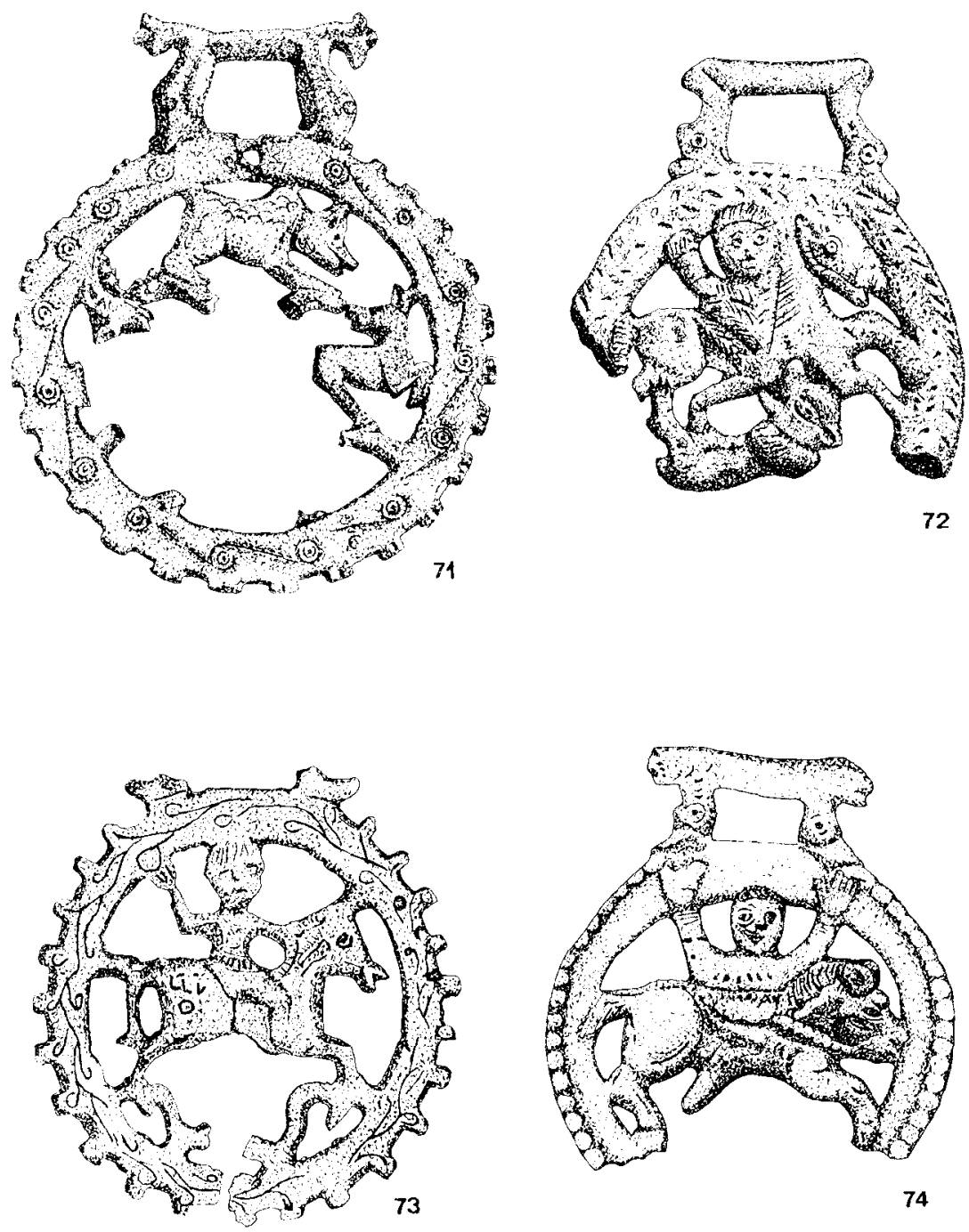

Fig. 21. Camas procedentes de: 71 , Sevilla; 72, El Coronil; 73, procedencia desconocida; 74, Cártama. 
oso y del ciervo, gracias al tratamiento, tienen volumen. El paso de filete, hoy fracturado, venía determinado por las patas y grupas de los animales. El enganche de montante es de forma rectangular. Parece que podria corresponder al mismo molde que la $\mathrm{n}^{\circ} 71$, habiendo sido retocada posteriormente a lima. Dimensiones: $11^{\prime} 0 \mathrm{~cm}$. de altura y $9^{\prime} 2 \mathrm{~cm}$. de diámetro.

71.- Sevilla (?) ${ }^{113}$. Museo Episcopal de Vic (Gerona) ( $n^{\circ}$ inv. 16.488). Cama circular cuyo anillo externo está ornamentado por pequeñas digitaciones rectangulares. La superficie de este anillo presenta unos circulos concéntricos unidos entre si por medio de diagonales. La zona central de la cama presenta una decoración, hoy en parte perdida, de animales girando en torno al anillo. Se observan todavía en la parte superior central un oso y en la derecha un perro, volviendo la cabeza hacia atrás. Junto a las patas posteriores del oso se localiza la cornamenta de un ciervo. El paso de filete debió situarse en el centro. El enganche de montante cuadrangular, presenta unas asas en forma de delfin. El hocico se apoya sobre el anillo y las colas trilobuladas corresponden a los extremos del vástago horizontal. Parece que podria corresponder al mismo molde que la cama precedente $n^{\circ} 70$, habiendo sido retocada posteriormente a lima. Dimensiones: $9^{\prime} 0 \mathrm{~cm}$. de diámetro y $3^{\prime} 0 \mathrm{~cm}$. de altura el enganche de montante.

72.- El Coronil (Sevilla) ${ }^{114}$. Museo Arqueológico de Sevilla. Cama circular fracturada en la parte inferior, donde posiblemente se situaba el paso de filete. El anillo externo está ocupado por pequeños trazos oblícuos que parece forman una línea de escuadras superpuestas y cortadas. El centro de la cama presenta una escena de caza. Un caballo montado por un jinete caza un cuadrúpedo. El caballo, visto de perfil y mirando hacia la derecha, porta su cabezada y su crín se señalada por medio de unos trazos rectilineos horizontales. El jinete está también de perfil, pero la cabeza se dispone de forma frontal y alza el brazo derecho. El animal, quizás un jabali, se revuelca entre las patas anteriores y posteriores del caballo. El enganche de montante de forma cuadrangular, presenta en sus asas dos delfines que apoyan su hocico en el anillo externo. Dimensiones desconocidas.

\section{Camas con decoración de escenas: representaciones de caballos montados}

Este grupo está compuesto por cuatro camas, cuya característica común es la de representar un caballo montado por su jinete. Este último suele llevar un brazo, o los dos, levantados.

73.- Procedencia desconocida ${ }^{115}$. Metropolitan Museum (Nueva York, USA) ( $n^{\circ}$ inv. 199077). Cama circular. El anillo externo está provisto de pequeñas digitaciones y de una ornamentación vegetal esquematizada incisa. La parte central está ocupada por un caballo montado por su jinete. El caballo, visto de perfil, avanza hacia la derecha. En el anca está inscrita la marca de la cuadra: CLD y debajo un círculo. El jinete también de perfil pero con visión

113 PALOL 1989, p. 35-36, fig. 1 et 2.

114 PALOL 1989, p. 46, fig. 9.

115 De nuevo agradecemos a Katherine Rernolds Brown, Conservadora del Metropolitan Museum of Art de Nueva York, el habernos comunicado y proporcionado la documentación necesaria sobre esta magnifica cama. 
frontal va vestido con túnica corta. Tiene el brazo derecho alzado y con el izquierdo sujeta las riendas. Bajo las patas del équido aparecen unos tallos vegetales esquematizados, parcialmente fracturados, donde debió situarse tambièn la perforación para el paso del filete. El enganche de montante lleva delimitado su espacio por medio de dos digitaciones, pero está fracturado y perdido. Por la posición del caballo y del jinete, esta cama estaria situada en la parte derecha del freno. Dimensiones: $8^{\prime} 3 \mathrm{~cm}$. de diámetro.

74. - Cártama (Málaga) ${ }^{116}$. Museo Arqueológico de Málaga. Cama circular cuyo anillo externo está ornamentado por medio de una línea de botones circulares. La zona central de la cama está provista de una decoración. Se trata de un caballo montado. El caballo visto de perfil, avanza hacia la derecha. Se remarcan bien la crin y las riendas. El jinete, visto frontalmente, levanta los brazos y va vestido con túnica corta. Las manos se apoyan directamente sobre el anillo externo. La parte inferior de la cama está fracturada y en ella se situaba la perforación para el paso del filete. El enganche de montante, presenta un vástago transversal con extremos resaltados. Las asas presentan la esquematización probable de unos delfines. Por la posición del caballo y el jinete, esta cama debió situarse en el lado derecho del freno. Dimensiones: $7^{\prime} 5 \mathrm{~cm}$. de diámetro y $1^{\prime} 5 \mathrm{~cm}$. de altura el enganche de montante.

75.- Procedencia desconocida ${ }^{117}$. Ariadne Galleries (Nueva York, USA) (?). Formaba parte del mismo freno que la pieza $n^{\circ} 76$ y se situaba en el lado derecho. Muy probablemente procede de la copia de la misma imagen pero no del mismo molde. Cama circular. El anillo externo se halla recorrido por una serie de digitaciones rectangulares dobles. La superficie de este anillo presenta tres líneas incisas. La parte central de la cama está ocupada por un caballo montado por su jinete. El jinete, con visión frontal, levanta el brazo derecho. Parece vestido con un pectoral. El caballo, de perfil y hacia la derecha, presenta en el anca una hedera. En la espalda quizás hubiera inciso un círculo, como vemos bien en el caballo de la cama $n^{\circ} 76$. Las patas anterior y posterior incisas con pequeños trazos transversales, se apoyan sobre unos tallos vegetales en forma de "s", que bien podrian representar también serpientes. En el centro y bajo el caballo se sitúa la perforación circular del paso de filete, del cual todavía se conservan abundantes restos férreos. El enganche de montante viene determinado por dos vástagos en forma de circulo abierto. Dimensiones desconocidas.

76.- Procedencia desconocida. Ariadne Galleries (Nueva York, USA) (?). Formaba parte del mismo freno que la pieza $n^{\circ} 75$ y se situaba en el lado izquierdo. Procede, muy probablemente, del mismo molde. Cama circular igual a la anterior, aunque presenta ligeras diferencias referidas a la decoración. Caballo y jinete miran a la izquierda. La cabezada del caballo está muy bien señalada. En la grupa aparece la marca de cuadra: una hedera; y en la espalda, un círculo. El jinete alza el brazo izquierdo. Dimensiones desconocidas.

16 E. Serrano Ramos y A. de Luque Moraño, "Una villa romana en Cártama (Málaga)", Mainaké, I, 1979 , p. 147-164, cf. p. 157, lám. IV.

117 Conocemos estas dos camas gracias a la documentación que nos proporcionó Dafydd Kidd, Conservador del British Museum de Londres, cuando hace varios años hubo una proposición a compra. Posteriormente estas piezas fueron perseguidas por la Policia Judicial. Su paradero actual es por tanto desconocido, pero creemos que deben formar parte de la colección de Ariadne Galleries de Nueva York, aunque no aparecen en su catálogo. 

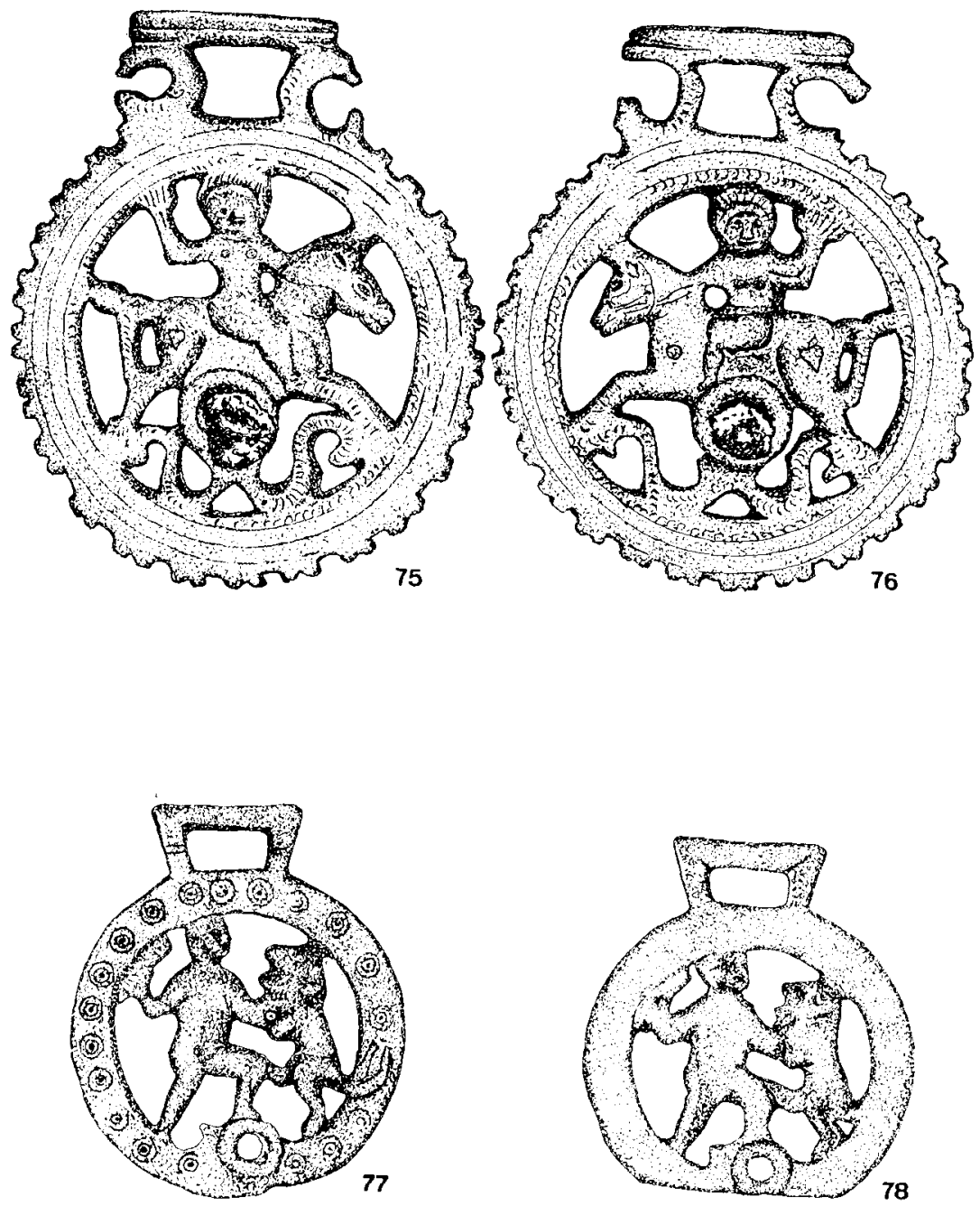

Fig. 22. Camas procedentes de: 75 a 78 , procedencia desconocida. 


\section{Camas con decoración de escenas mitológicas}

Las dos camas de este grupo, probablemente correspondientes al mismo freno, presentan una escena excepcional. Se trata de uno de los trabajos de Hércules.

77.- Procedencia desconocida ${ }^{118}$. Museo Lázaro Galdiano (Madrid) ( $\mathrm{n}^{\circ}$ inv. 1.181). Cama circular cuyo anillo externo está ornamentado con motivos de círculos concéntricos. La zona central está ocupada por una escena: un hombre de pie, mirando hacia la derecha, sostiene una maza con la mano derecha y lucha contra un león rampante. La cola del león se dispone sobre el anillo externo. El hombre apoya la pierna izquierda sobre la perforación del paso de filete, situada en la parte inferior de la cama. El enganche de montante de forma rectangular. La escena, de carácter mitológico, alude a uno de los trabajos de Hércules, el de la lucha contra el león de Nemea. La pieza es igual a la $n^{\circ} 78$ y podría proceder del mismo freno y del mismo molde. Dimensiones: $6^{\prime} 0 \mathrm{~cm}$. de diámetro.

78.- Procedencia desconocida ${ }^{119}$. Museo Lázaro Galdiano (Madrid) ( $\mathrm{n}^{\circ}$ inv. 1.185). Cama circular igual a la precedente $\left(n^{\circ} 77\right)$, salvando pequeñas diferencias referidas a la decoración pues ésta se halla muy desgastada. La parte inferior del anillo externo parece haber sido recortado o limado (?). Mismas dimensiones.

\section{INTERPRETACIÓN DE LAS CAMAS CON DECORACIÓN GEOMÉTRICA}

El grupo más importante de camas de frenos de caballos lo componen, sin lugar a dudas, aquellas cuya decoración es geométrica, ya sea a base de radios rectos, curvos, arcos calados o estrellas.

En nuestra serie hemos situado en primer lugar las que son filiformes $\left(n^{\circ} 1,2,3\right.$, 8 a 11), es decir, aquellas que se componen de un aro y no llevan prácticamente ningún tipo de decoración. Su contextualización estratigráfica, en el caso de la cama de Conímbriga $\left(n^{\circ}\right.$ ) aparecida en un nivel del 310-315 d.C. permite decantarnos por una cronologia relativa. El paralelismo con el mosaico del caballo de la villa de Dueñas, citado anteriormente, donde un freno de este tipo está representado con toda fidelidad es lo más cercano que conocemos (fig. 1). En este mosaico del siglo IV, toda la cabezada y freno del equino están representados, pero la cama en si misma es exactamente igual a las que hemos visto de Conímbriga o Fuentespreadas. Todo ello permite situar estos frenos en el siglo IV y principios del $\checkmark$ d.C. Cronología que viene también confirmada por los hallazgos de la necrópolis de Fuentespreadas.

Sobre las piezas halladas con un filete articulado $\left(n^{\circ} 4\right.$ a 11 y 25 a 28 ) no nos detendremos de nuevo aqui pues ya lo hemos hecho al principio de estas páginas.

118 PALOL 1952, p. 309-310, fig. 5. 19.

119 PaLOL 1952, p. 309-310, fig. 5. 20. 
Una pieza inhabitual dentro de esta serie es la conservada en el Museo Episcopal de Vic $\left(n^{\circ} 12\right)$, pues se trata de una pieza totalmente rigida y la decoración está prácticamente ausente. Cabría plantearse si se trata de un objeto que no ha sido acabado ${ }^{120}$, o bien que morfológicamente presenta semejanzas de camas rigidas recortadas sobre plancha de bronce.

A este ejemplar le siguen las camas con radios que oscilan entre un número de cuatro y diez ( $n^{\circ} 13$ a 22). Algún autor ha querido ver en este tipo de esquema un monograma cristológico ${ }^{121}$. Es decir, aquellas camas con cuatro radios, representarían una cruz, y aquellas con ocho, la de una cruz y un crismón. Nosotros no insistiremos en ello, pues tenemos nuestras reservas sobre este tipo de interpretaciones. Son muy abundantes las camas de tipo geométrico aparecidas en el Norte de África, tanto en Argelia - aunque menos- como en Marruecos ${ }^{122}$. Esta abundancia lleva a pensar en la absoluta dependencia entre ambas regiones 0 al menos su clara conexión comercial ${ }^{123}$.

Del grupo de camas con decoraciones geométricas es interesante detenerse en las piezas con calados escutiformes o de arcos de herradura, como son las piezas de Pollentia y de procedencias desconocidas $\left(n^{\circ} 29\right.$ a 35$)$. El hecho es que existen, tal como hemos avanzado precedentemente, algunos broches de cinturón de los siglos IV y $V$ d.C., que en su placa presentan un calado de este mismo tipo. Podrían traerse a colación los clásicos ejemplos de San Miguel del Arroyo (Valladolid) ${ }^{124}$. El hecho de poder presentar este tipo de paralelismo en objetos de bronce permite afirmar con cierta seguridad que las cronologias propuestas para estas piezas son relativamente fiables $y$, que a nivel hipotético, pueden inducir a la reflexión.

\section{INTERPRETACIÓN DE LAS CAMAS CON CRISMÓN}

Más arriba apuntábamos — reservando nuestra opinión- la teoría de algunos autores sobre interpretar las camas de cuatro $\mathrm{u}$ ocho radios como el monograma cristológico. Por otro lado existe la serie de camas $\left(n^{\circ} 36\right.$ a 41) con la representa-

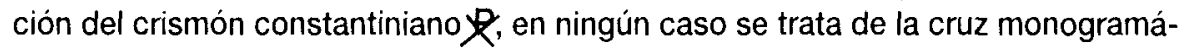
tica $\mathcal{P}$. Por regla general este aparece en los ejes de la superficie central de la cama y la decoración tanto del anillo externo como de la cama del propio crismón, suele ser muy somera. Sólo en un caso, el del RGZM ( $\left.{ }^{\circ} 41\right)$ (fig. 23) de los brazos

120 PALOL 1989, p. 44.

121 Marcos Pous y ViCENT, "Dos camas de freno de cabalio...", op. cit., p. 36.

122 Ch. BOUBE PICCOT, "Phalères de Maurètanie Tingitane", Bulletin d'Archéologie Marocaine, V, 1964, p. 144-181, XIII, pl., 1 fig.

123 Boube PICCOT, Les bronzes antiques du Maroc..., op. cit.

124 PALOL, "La necrópolis de San Miguel del Arroyo...", op. cit., p. 93-161. 

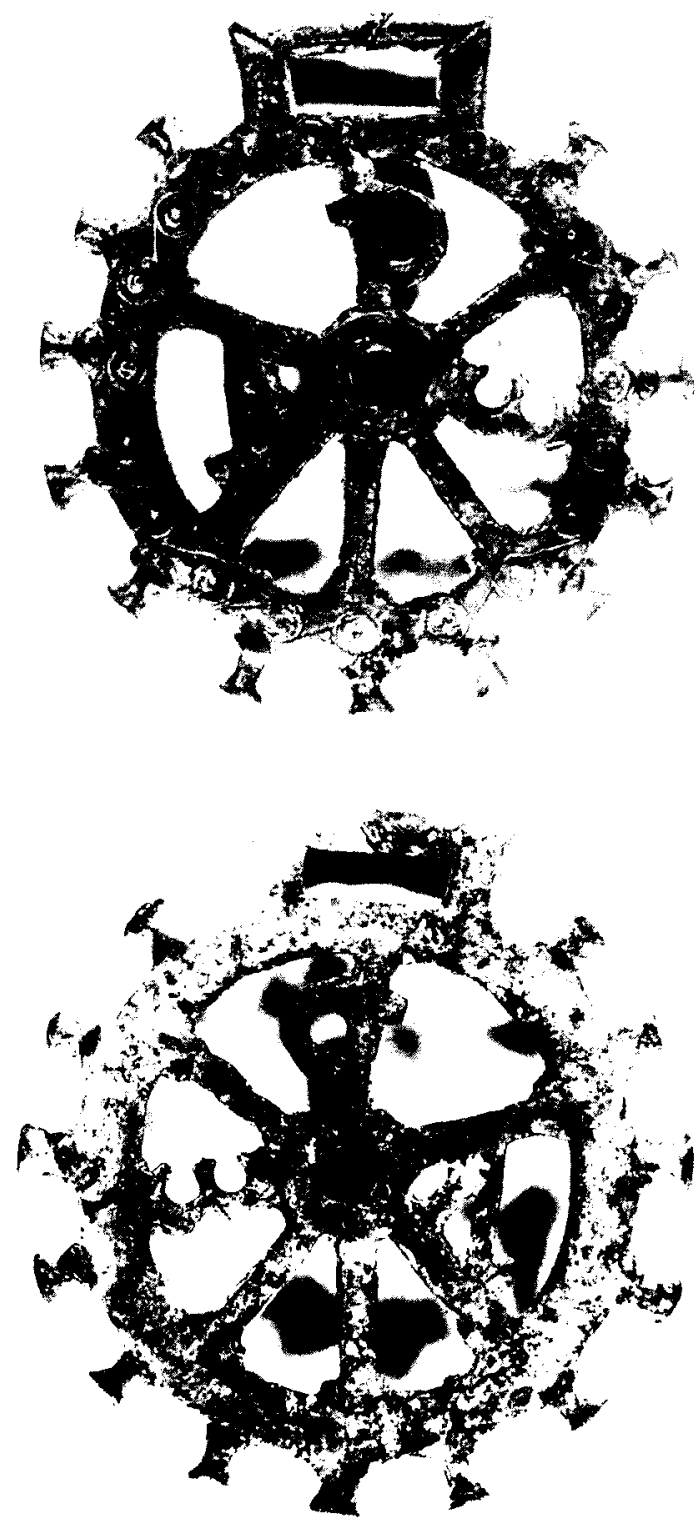

Fig. 23. Anverso y reverso de la cama $n^{\circ} 41$ conservada en el RGZM. 
de la rho penden el alpha y la omega; pieza, por otra parte de una excelente calidad y una perfecta factura que no se repite en prácticamente ninguna otra de las camas enumeradas.

El hecho de que aparezca el crismón en este tipo de objetos es relativamente significativo desde un punto de vista cronológico pues los sitúa siempre en el período constantiniano o postconstantiniano, aunque no nos dice nada sobre su último momento de utilización, pues el crismón es un tema frecuente en toda la plástica cristiana y de la antigüedad tardia, y es un hecho común y banal el que aparezca en las inscripciones tanto sepulcrales como no, a partir del año 350.

Queda por aclarar el porqué aparece un crismón en un objeto cuya funcionalidad está bien clara, como es un freno de caballo. ¿Se trata de una voluntad precisa por parte del propietario del caballo, o del jinete, en mostrar su convicción cristiana? ¿Se quiere así aludir a la victoria de Cristo? ¿Se pretende recalcar de esta forma tan arbitraria el triunfo del cristianismo sobre la religión romana pagana? Por otra parte se conocen algunas asociaciones donde aparece el crismón con el caballo, y un ejemplo flagrante lo proporciona la inscripción de Tharros (Cerdeña) donde en la grupa de un caballo aparece un crismón a modo de marca de cuadra ${ }^{125}$. ¿Se pretende en esta imagen, de nuevo, ensalzar la victoria de Cristo? También existe una larga serie de lucernas donde el monograma de Cristo se inscribe sobre la grupa del équido ${ }^{126}$, que por regla general se pone en relación con el aspecto de suerte y victoria del caballo en la carrera.

\section{INTERPRETACIÓN DE LAS CUESTIONES EPIGRÁFICAS Y DE DETERMINADAS REPRESENTACIONES EQUINAS}

Hemos visto que un número total de seis ejemplares de camas, lleva una inscripción, ya sea incisa ( $n^{\circ} 46,47$ y 48 ), ya sea calada $\left(n^{\circ} 43,44\right.$ y 45$)$. Por el tipo de inscripción y del propio material, creemos que se debe reflexionar con especial atención sobre ello.

Empezamos abordando aquellos ejemplos de camas donde aparece la fórmula ex officina $\left(n^{\circ} 44\right.$ y 46 ) (fig. 24). Se trata de una fórmula muy generalizada a partir del siglo IV y probablemente perdura hasta el siglo VII ${ }^{127}$. Quizás el ejemplo más antiguo de esta fórmula en Hispania lo encontremos en la inscripción fechada en el

125 Noël Duval, "Une mensa funéraire de Tharros (Sardaigne) et la collection chrétienne du Musée de Cagliari", Revue des Etudes Augustiniennes, XXVIII, 1982, p. 280-288, cf. fig. 1.

126 Hans KLUMBACH, “Pferde mit Brandmarken", Festschrift des Römisch-Germanischen Zentralmuseums in Mainz zur Feier seines hundertjährigen Bestehens, 1952, Maguncia, 1952, vol. I, p. 1 12, 14 fig. cf. p. 6-7, fig. 7-9.

127 BALMELLE y DARMON, "L'artisan-mosaïste...", op. cit., p. 235-253. 


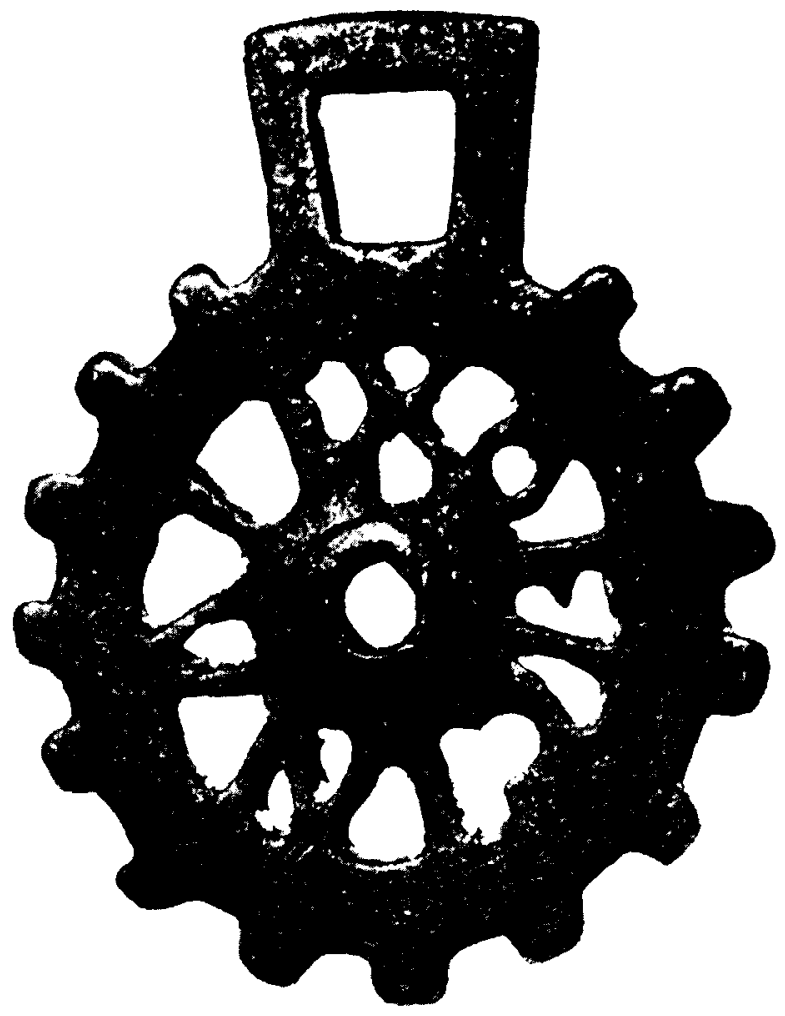

Fig. 24. Cama de procedencia desconocida, $n^{\circ} 44$, con inscripción.

año 387 procedente de Granátula (Oretum, Cartaginense) del taller de Homonius: Ex officina Homoni./ utere Felix Vasconi/ in px.proc. Tiberiano/ factus est horreus d.n. Valentiniano Aug./ ter. et Eutropio u.c. cons. scrib. Elefantol [...]t Vill...] et Neb[... ${ }^{128}$. Varios son los ejemplo de este tipo de fórmula que se encuentran sobre mosaicos, así por ejemplos el de la uilla de Tossa de Mar en Gerona, en el que se lee: salvo/ Vitale felix Turissa./ ex officina Felices ${ }^{129}$. Otro mosaico aunque posiblemente más tardio - del siglo $\mathrm{V}$ - es el de Mérida con la inscripción ex officina Annius Bonius ${ }^{130}$. También podemos aportar el testimonio de uno de los ladrillos

128 VIVES, Inscripciones cristianas..., op. cit, , p. 128, n. 367.

129 Vives, Inscripciones cristianas..., op. cit., p. 129, n. 368 b.

130 A. Blanco Freljelro, Mosaicos romanos de Mérida, "Corpus de Mosaicos romanos de Espana", I, Madrid 1978, p. 34, n. 15. A. Balil, "Algunos mosaicos hispanorromanos de época tardia", Principe de Viana, XXVI, 1965, p. 281-293, cf. p. 281. 
comunes en los siglos V y VI, donde se lee: Ex off(icina) Canti utere felix Senti ${ }^{131}$ Ya de cronologia más tardía es la inscripción que aparece sobre un fragmento de Mérida, fechable hacia el siglo VI: [fe]lix amen (?) felix Castrice [....e]x officina Auiti utere [felix] ${ }^{132}$.

Todo ello nos hace pensar que las camas con fórmula ex officina se sitúan cronológicamente entre finales del siglo IV y el siglo VI. Es muy posible que la cama con la inscripción calada $\left(n^{\circ} 44\right)$ tuviese una cama gemela al otro lado del freno, donde figuraria el propio nombre del taller. En aquélla que lleva la inscripción incisa $\left(n^{\circ} 46\right)$ no sería necesario que existiera una cama gemela para situar el nombre del taller, pues, como hemos visto, ya lo lleva inscrito. Se trataría de Neclectus, aunque hemos hecho alusión, en el momento de definir la cama, a los problemas que esta lectura planteaba. La decoración de la cama calada $\left(n^{\circ} 44\right)$ es muy visible y no deja de sorprender el hecho de que se presente de forma tan alusiva el taller de procedencia de la pieza; pues es sabido que normalmente la firma del taller de producción, ya sea de objetos o de mosaicos, figura en lugares discretos o al menos no tan visibles como este.

Pasaremos ahora a estudiar la inscripción de la pieza de Almazarrón (Cartagena, Murcia) $\left(n^{\circ} 43\right)$ que habia sido publicada por J. Vives como una bulla, siguiendo la información dada por Hübner ${ }^{133}$. El hecho de clasificar la fórmula, Sce Pauline uiuas eteoris/ et semper sedas (según la lectura de Hübner), en las aclamaciones inter vivos, es bastante verosímil, pero no existe ningún otro paralelo. Las otras fórmulas aclamatorias clásicas, y por otra parte mucho más frecuentes, son: uiuas in Christo, uiuas cum tuis, etcétera. Éstas presentan sólo una similitud de transfondo pero no propiamente de forma. Dada la imposibilidad de comprobar la inscripción, es dificil poder determinar una lectura concreta, puesto que sólo podemos recurrir a las anotaciones de los estudiosos, ya citadas, y que, además, tal como dice Vives, ya entonces era de lectura difícil a causa de su mala conservación. Así pues, donde existe mayor confusión es en eteoris. Dos son las posibilidades que han sido sugeridas, una eternis y la otra et oris; a estas podriamos añadir una tercera, etheris (?). En todas ellas existirian errores gráficos o de lectura: oris respondería a oras siendo extraña esta confusión ante la corrección de las dos terminaciones de uiuas y sed(e)as; etheris de aether, no aportaria el caso correcto para la concordancia con uiuas; y eternis de aeternus aunque en dativo o ablativo plural y quizás donde esperariamos mejor aeternum, pudiera ser la posibilidad más fácil de todas. En todo caso, la intención de la expresión es clara y no deja duda. Se trata de una aclamación común, como es el caso sobre objetos de adorno personal tales como una hebilla de la colección

VIVES, Inscripciones cristianas..., op. cit., p. 128, n. $368 \mathrm{a}$

132 VIVES, Inscripciones cristianas..., op. cit., p. 128, n. 368.

133 VIVES, Inscripciones cristianas..., op. cit., p. 137-138, n. 401. 
del RGZM y otra exactamente igual procedente de Ortigosa de Cameros (Logroño) ${ }^{134}$, con la fórmula Christus sit tecum. Con ello queremos recalcar la aparición de este tipo de aclamaciones en objetos de uso corriente, como pueden ser los broches de cinturón o las camas de frenos de caballos ${ }^{135}$. En lo que a la onomástica respecta es difícil precisar a quien se refiere concretamente el nombre de Paulino, aunque se haya querido entender que se trataba de un obispo de cuya existencia no se tiene ningún dato preciso. Para las cuestiones y problemas cronológicos las hebillas que hemos mencionado no nos aportan ningún dato concreto, aunque pueden ser fechadas a finales del siglo VI o ya en el siglo VII.

La otra cama que debemos estudiar aqui es la hallada en la uilla de Pedrosa de la Vega (Saldaña, Palencia) ( $\left.n^{\circ} 45\right)$ con la inscripción calada de Asturi uiuas, fechada en el siglo V. En un primer estudio, P. de Palol ${ }^{136}$ consideró Asturius como el nombre de un caballo. Para ello se sirvió como punto de comparación de una pieza de Tamuda (Tetuán, Marruecos) ${ }^{137}$ en la que se lee u[.]rbone vivas (donde debe interpretarse uirbone) ${ }^{138}$ (fig. 25). En ésta además, se debe señalar que entre la $u$ (“inicial») i la s ("final») se encuentra un radio (hedera?) como signo de puntuación o separación indicando el orden de lectura, como también encontramos en la cama de procedencia desconocida, $n^{\circ} 44$, donde leemos Ex officina, y que la disposición entre las letras no permite determinar o concretar con claridad la separación exacta entre las palabras; asi pues no se puede afirmar si uirbone estaría junto o separado aunque por significado simplemente aportaria una diferenciación de matiz de la exclamación. Más tarde P. de Palol se corrige y afirma que Asturius "es un nombre propio masculino. Perteneció a Asturius y el deseo de vida sería muy vano que se expresase dedicado a un caballo cuando es una fórmula normal paleocristiana en anillos de matrimonio..." ${ }^{139}$. De este modo, este autor consideró que la cama perteneció a Asturius que era dux utriusque militiae de Hispania entre los años 441 y 443, y que tuvo como misión reprimir la revolución de las bagaudas de

134 Para la pieza del RGZM: Ripol, L'archéologie funéraire de Bétique..., op. cit., p. 244, fig. 40.43, lám. IX. 43.a y 43.b. Para Ortigosa de Cameros: Hans ZEISS, Die Grabfunde aus dem spanischen Westgotenreich, Berlín-Leipzig, 1934, p. 93 y 195, lám. 15. 2.

135 El hecho que ambos formularios sean semejantes induce a un cierto paralelismo cronológico y a un mismo deseo por parte del propietario.

136 PALOL 1967, D. 239-240.

137 Pelayo Quintero ATAuRI, Estudios varios sobre los principales objetos que se conservan en el Museo, Museo Arqueológico de Tetuán, 1942, p. 54, lám. XXX. Boube PICCot, Les bronzes antiques du Maroc..., op. cit., p. 356-357, lám. 125, fig. 614. G. RIPOLL y M. DARDER, "La rueda de freno de caballo hallada en Tamuda (Tetuán, Marruecos)", Actas del // Congreso Internacional El Estrecho de Gibraltar, Ceuta, 1991 (en prensa). RRONE.

138 PALOL 1953-54, p. 283; proponía $V(I)$ BONE, pero dudaba también entre ésta y $V(E)$ BONE o $V(E)$

139 PALOL y CORTES, La villa romana de la Olmeda..., op. cit., p. 97. PALOL, La villa romana de la Ormeda..., op. cit., p. 54. 


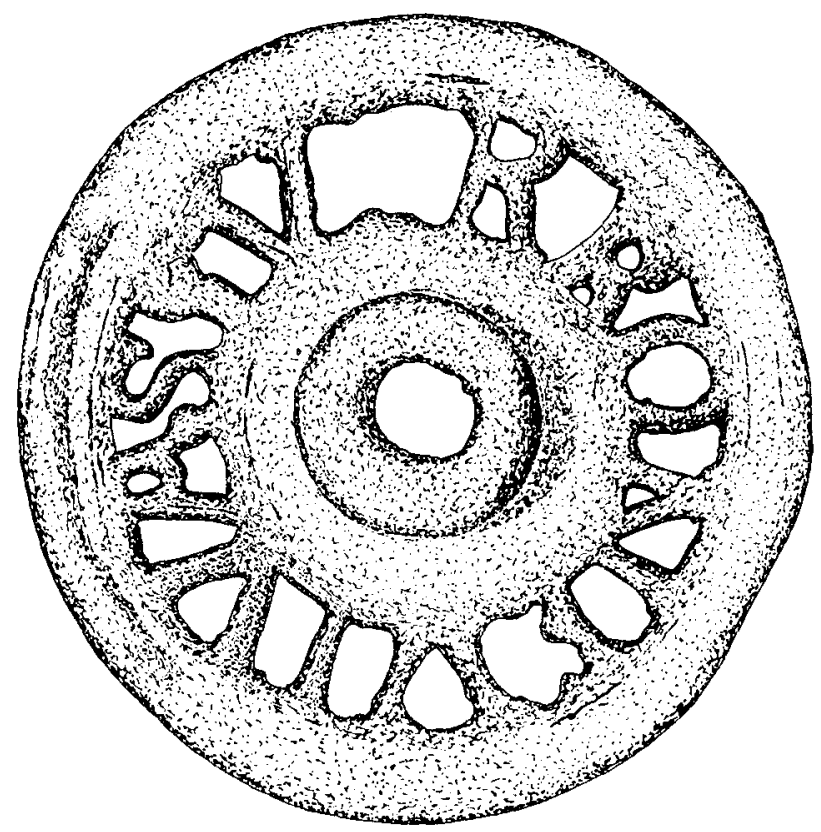

Fig. 25. Cama procedente de Tamuda (Tetuán) (según G. Ripoll y M. Darder, 1991).

la Tarraconense. Hidacio hace referencia a ello ${ }^{140}$ : Astirius dux utriusque militiae ad Hispanias missus Terraconensium caedit multitudinem Bacaudorum.

Sin embargo, para dilucidar con exactitud la pertenencia del nombre de Asturius, debemos llevar a cabo un análisis pormenorizado de él y de su aparición en determinados contextos. El nombre en sí mismo indica el origen de Asturias, región hispánica conocida por tener caballos asturcones ${ }^{141}$. Asturius derivado por el sufijo -ius del substantivo Astur, - is ${ }^{142}$, designaba en un principio el gentilicio, para destacar el carácter de étnia y/o origen geográfico, substituyendo a Astur puesto que con el tiempo la fuerza semántica de éste tendía a disminuir. Igualmente debemos recordar el uso de Asturicus ${ }^{143}$ con el mismo significado que los anteriores. Así pues no sería de extrañar que Asturius estuviese en uso en los

140 Hydat., 24, Olymp. CCCV, 125.

141 Plinio, Hist. Nat. VIII, 67, 166: thieldones, minores froma apellatos asturcones.

142 RIPOLL y DARDER, «La rueda de freno de caballo hallada en Tamuda...», op. cit., p. 4.

143 Para la utilización del sufijo adjetival en los derivados utilizados como substantivos, sobre todo en época tardia: C.H. GRANDGENT, Introduction to Vulgar Latin, edición de F. MoLL, Introducción al latín 
siglos IV y V (asi lo corroboran los ejemplos que exponemos más adelante), correspondiendo por tanto en el caso que nos ocupa a éste nombre en vocativo formando la expresión exclamativa junto a uiuas. Se trata de un formulario de aclamación muy habitual a partir del siglo IV, como lo fueron también: uiuas in Deo o uiuas cum tuis. Hemos visto que este tipo de fórmulas pueden hallarse en broches de cinturón e incluso en objetos de uso corriente como en cucharillas, etcétera ${ }^{144}$. Existen varios paralelos de Asturius como nombre propio, como apelativo o supernomen. Algunos de ellos son interesantes de recordar en este caso, como por ejemplo el de la inscripción incisa sobre una pieza de juego encontrada en Rhenania donde figura Asturi ua ${ }^{145}$. Éste, fue interpretado, en un principio, como el nombre del caballo, pero debe aceptarse que se trata del nombre o supernomen del auriga, como es frecuente y habitual ante la forma -va; al lado de esta inscripción podemos leer Fortunio en ablativo instrumental, correspondiendo al nombre del caballo, seguramente el funalis izquierdo de una cuadriga de Asturius ${ }^{146}$. También en un contorniato leemos Asturius nika ${ }^{147}$, refiriéndose al auriga, $y$ apareciendo el nombre del funalis Botrocales en el reverso. Por otra parte, es un nombre habitual dentro de la prosopografía romana, recordemos por ejemplo el senador de la época de Galieno ${ }^{148}$; otro senador conocido por las cartas de Enodio ${ }^{149}$ y el dux utriusque militiae de Hispania, al que aludiamos anteriormente.

Las expresiones exclamativas citadas, formadas por un substantivo y un verbo, uiuas, nika o-ua, corresponden a inscripciones halladas sobre objetos de uso o relacionados con el mundo de los équidos, en unos casos responde a un contexto circense, en otros a uno de cacería o de paseo. Tanto nika como la abreviatura -ua se encuentran siempre acompañados - queda evidente por el contexto en que se hallan- por el nombre o supernomen de un auriga. Recordemos por ejemplo el mosaico de Mérida donde se aclaman los aurigas Marcianus y Paulus (seguidos por

vulgar, Madrid, 1991 ( $5^{\text {a }}$ ed.), p. 53; V. VÄANÄNEN, Introducción al latin vulgar, Madrid, 1982 (ed. española), p. 146-147. También son interesantes los comentarios sobre el nombre de pájaro astur en: J. ANDRE, Les noms d'oiseaux en latin, Paris, 1967, p. 34-35 s.v.

144 Las referencias sobre el objeto de Ortigosa de Cameros en nota 134. Cf. también Catherine JoHns y Timothy POTTER, The Therford Treasure. Roman Jewellery and Silver, British Museum Publications, Londres, 1983.

145 M. Bö, "Splielsteine als Rennpferde", Bonner Jahrbücher, 155-156, 1955-1956, p. 79 , n. 2.

146 Sobre el problema de -VA, cf. M. DARDER, "Noms d'aurigues i de gladiadors en dues peces de vidre d'Empúries", Espacio, Tiempo y Forma, s. II. 1 "Homenaje al Prof. Eduardo Ripoll Perelló́, 1988, p. 295-300.

14? A. ALFÖLDI, Die Kontorniaten ein verkanntes Propagandamittel der städtrömischen heidnischen Aristokratie in ihrem Kampfe gegen des christliche Kaisertum, Budapest-Leipzig, 1943, n. 551, lám. 593.

148 A.H.M. JonES, J.R. MARTINDALE y J. MORRIS, The Prosopography of the late Roman Empire, vol. I, A.D. 260-395, Cambridge, 1971, p. 120.

149 J.R. MARTINDALE, The Prosopography of the late Roman Empire, vol. II, A.D. 395-527, Cambrigde, 1980, p. 174, nota 4. 
las expresiones nicha y nica) ${ }^{150}$, o una lucerna donde se anota $A q(u) i l o$ va ${ }^{151}$. Igualmente para el caso de -ua resulta interesante un vaso de Colchester ${ }^{152}$ con una representación circense donde encima se lee: hieraxua olympaeva antiloceva cresceva ${ }^{153}$, todos ellos corresponden a los nombres de cada uno de los agitatores que participan en la escena. Otra de las fórmulas usadas para aclamar al auriga la encontramos en una inscripción donde leemos marcil ane ue/ ncas ${ }^{154}$. Con estas anotaciones no pretendemos poner al mismo nivel la expresión uiuas con las otras tres, sino, plantear cómo el uso de esta estructura exclamativa de sujeto en vocativo y verbo de victoria se encuentran en contextos donde se está aclamando a un individuo y no a un animal. Así pues, podemos afirmar que uiuas está acompañado por un substantivo que corresponde a una persona, propietario o jinete del caballo, y no al propio équido. Por el momento, no ha aparecido ningún nombre de equino en las fórmulas citadas. Cuando aparece únicamente el nombre del caballo, éste está en nominativo y cuando lo hace junto al del auriga puede estar en nominativo o en ablativo, a excepción de algunas defixiones donde aparecen en acusativo ${ }^{155}$.

Por otro lado, tal como hemos podido comprobar, a partir de los paralelismos onomásticos y sintácticos aducidos hasta el momento - y corroborado en este caso por el contexto sintáctico de la inscripción de la pieza que nos ocupaAsturius corresponde al nombre o supernomen de un individuo. Por consiguiente, podemos afirmar que los substantivos en vocativo acompañados de uiuas responden al apelativo del propietario del caballo, del freno del équido. En el caso de la cama de Tamuda, se puede entender uirbone o uir bone; nos encontrariamos o bien ante un substantivo o bien ante una exclamación formada por un substantivo y un adjetivo que acompañan al verbo uiuas. Por los paralelos conocidos es preciso suponer que se trata de una sola palabra -aunque semánticamente el significado no cambia - que correspondería a un apelativo o, incluso mejor, al supernomen del propietario del freno. Por tanto, tal como hemos dicho, Asturi de la cama de Pedrosa de la Vega correspondería al propietario del freno donde está inscrito, y aparentemente y según los ejemplos antroponímicos citados esta pieza podría situarse entre los siglos IV y $\vee$ d.C., aunque con reservas.

Entre las camas de freno de caballo que debemos estudiar y que llevan inscripción queda aquella con el nombre de Tagus $\left(n^{\circ} 48\right)$. Como hemos descrito, la inscripción se hallaba inscrita dentro de una tabella situada enfrente de la imagen de un

150 Blanco Freijeiro, Mosaicos romanos, op. cit., col. I, p.45-46, n. 438, lám. 77-78a.

151 CIL XV, 6258.

152 D.B. HARDEN, Glass of the Caesars, Milán, 1987, p. 168.

153 DARDER, "Noms d'aurigues i de gladiadors...", op.cit., p. 295-300.

154 C/L VI, 4. 2. 33962.

155 Marta DAROER LISSON, Els noms de cavalls circencs a l'occident romà, Tesis Doctoral, Universitat Autónoma de Barcelona, Barcelona 1993 (pro manuscripto), (a partir de ahora citado como: DARDER, NCCOR). 
caballo. En el dibujo publicado por P. de Palol ${ }^{156}$ no se marca la inscripción, pero no por ello debemos dudar de su existencia. Es habitual, tanto en mosaicos y contorniatos como en otros muchos documentos ${ }^{157}$, que junto a la imagen de un caballo aparezca su nombre. Creemos que también en este caso nos encontramos ante el nombre del caballo. El rio Tagus (actual Tajo) que cruza las provincias Carthaginensis y Lusitania era conocido por la - tantas veces mencionada - leyenda referente a las yeguas preñadas por el viento, caballos de las cuales eran veloces por ser hijos del viento ${ }^{158}$. Existe un gran número de caballos circenses llamados por medio de nombres de ríos testimoniados sobre todo tipo de soporte; entre algunos de ellos podemos citar: Borysthenes, Danuvius, Eridanus, Eufrata, Hiberus, Inachus, Indus, Nilus, etcétera. Estos nombres poseen un sentido mucho más amplio que el inmediato pues recuerdan a la vez los lugares que atraviesa cada uno de estos rios y que en general son zonas famosas por la cría. Se establece, por tanto, un paralelísmo simbólico entre la ligereza, la fertilidad y, sobre todo, la rapidez de los fluviales, debido no sólo a las leyendas aducidas, sino también al contínuo movimiento real de las aguas ${ }^{159}$. Tagus como nombre de caballo puede fecharse, por los paralelos que se encuentran en el occidente romano, en el siglo IV (seguramente, finales), pues aparece en defixiones de Hadrumetum (Norte de África), y en un mosaico de la uilla romana de Aguilafuente (Segovia). Las tabletas de execración, en las que aparece Tagus cuatro veces (seguramente responde a un mismo caballo) ${ }^{160}$, deben ser fechadas, según las aportaciones de recientes hallazgos de defixiones en el circo de Carthago publicadas por Jordan ${ }^{161}$, alrededor del año 400 , y no entre los siglos II y III d.C. como propuso Audollent. Por otro lado, parece ser que el mosaico de Aguilafuente puede fecharse, con bastante seguridad, en el siglo IV ${ }^{162}$. Este documento, donde junto a Tagus se halla Eufrata, también como nombre de caballo, es muy interesante a nivel iconográfico. En la imagen aparecen dos parejas de caballos afrontados atados a una palmera sobre cuyos lomos figuran sus nombres. Ésta responde a una típica representación de caballos circenses vencedores frecuente en mosaicos del Norte de África (como en los dos de Sorothus de Hadrumetum), y que encontramos también en un ladrillo decorado procedente de Osuna (Sevilla) ${ }^{163}$ y en una extraordinaria cama de freno de caballo hispana ( $n^{\circ} 53$ ). Igualmente, y más cercanas a la pieza que nos ocupa, encontramos tanto en Hispania como en el resto de la pars occidentis y en

156 PaLOL 1952, p. 311, fig. 5. 21 (véase nuestro inventario $n^{\circ} 47$ ).

157 Ver nota 12; y A. AlföldI et E. Alföld, Die Kontorniat-Medaillons, Berlin, 1976 y 1990.

158 Plinio, N.H., IV. 35.

159 DARDER, NCCOR, S.v., Fontanus o Nilus.

160 A. Audollent, Defixionum tabellae..., Paris, 1904, n. 275, 276, 282a y 284.

161 D.R. JoRDAN, "New defixiones from Carthage", en J.H. HUMPHREY, The circus and the Cemetery at Carthage, Michigan, 1988, p. 117-134.

162 LUCAS PELLICER, "La influencia africana...”, op.cit., p. 219-235.

163 H. SChlunk y Th. HAUSCHILD, Die Denkmäler der frühchristlichen und westgotischen Zeit, Hispania Antiqua, Maguncia, 1978, p. 177, lám. 72a. La cronologia propuesta y dada sin un contexto arqueológico, es del siglo II-III d.C. Creemos que deberia ser revisada. 
diferentes tipos de soportes, imágenes de caballos vencedores aislados con la inscripción de su nombre. Recordemos por ejemplo, entre otros muchos testimonios, los caballos de Torre de Palma (Monforte, Portugal) ${ }^{164}$, las piezas redondas y de marfil de juego de la tumba de San Sebastian (Roma) ${ }^{165}$, algunos contorniatos como el de Amor y Toxxotes o el de Pyrolampes ${ }^{166}$ o algún fondo de vaso de cristal como el de Preatus ${ }^{167}$.

Así pues, ¿podriamos afirmar que el caballo Tagus de la cama de freno que nos ocupa fuese un équido circense? Intentar discernir en el documento que nos ocupa $\left(n^{\circ} 48\right)$ si se trata de la representación de un caballo de parada o circense, se hace bastante difícil; por un lado, como hemos visto, las imágenes de caballos vencedores abundan, pero por otro, en el dibujo de la cama, parece que el équido lleva insinuada sobre el dorso una silla de parada o una media manta. Así mismo, no creemos que el hecho de que aparezcan motivos vegetales en la parte inferior de la cama permita afirmar taxativamente que estemos ante la palma de la victoria ${ }^{168}$. Considerar dicho motivo como un símbolo de victoria agonistica es aventurarse excesivamente en la interpretación, al igual que lo es el ver como símbolo de la victoria en la pieza $n^{\circ} 47$ los pequeños trazos en forma de espiga del anillo externo ${ }^{169}$. Si afirmamos que nos encontramos ante un símbolo de este tipo, significa que aceptamos que se trata de caballos circenses, pero no creemos que el material, en si mismo, permita ir tan lejos. Sólo puede ser tenido en cuenta como hipótesis u observación, que nos parece queda bastante matizada por los comentarios anteriores al respecto y por la propia funcionalidad de estas camas en frenos de caballos esencialmente de parada o paseo, y no destinados a las carreras.

Otras imágenes, también con motivos equestres, las ilustran los caballos con jinete de las camas de frenos $n^{\circ} 72$ a 76. La pieza del Metropolitan Museum ( $n^{\circ} 73$ ) presenta también un tipo de decoración vegetal en el anillo externo, el caballo lleva la marca de la cuadra en el anca y está montado. Pese a la decoración vegetal, parece evidente que se trata de un caballo de parada (¿quizás de exhibición?, sobre todo los $n^{\circ} 73$ a 76). No por la aparición de motivos muy usuales en escenas determinadas debemos presuponer que sólo aparecerán en éstas. Es muy proba-

164 Con buena documentación gráfica: J. LANCHA y C. BEL.oTÓ, Chevaux vainqueurs. Une mosaïque romaine de Torre de Palma, Portugal, Lisboa, 1993.

165 Piezas de marfil: Alföld y Alföld, Die Kontorniat-Medaillons, op. cit., lám. 270.1 a 4.

166 ALFÖLDI y ALFÖLDI, Die Kontorniat-Medaillons, op. cit., Amor $=n^{\circ} 666$, lám. 207.7; Pyrolampes, $n^{\circ}$ 663, lám. 210.

167 Para Preatus: C.R. Morey, The Goldglass Collection of the Vatican Library, Cataloghi del Museo Sacro della Biblioteca Apostolica Vaticana, IV, Ciudad del Vaticano, 1959, p. 72, $n^{\circ} 443$, lam. 25.

168 No podemos afirmar con seguridad que se trate de una palma de la victoria cuando se trata de este tipo de decoración de linea de escuadras sobrepuestas y cortadas girando alrededor en el anillo externo de la cama. Se trata de un motivo muy habitual. Cuando se encuentra en posición vertical es más factible.

169 PALOL 1952, p. 310. 
ble que nos encontremos ante la reutilización de una iconografía reservada, sobre todo en un principio, para escenas circenses, pero adoptada, a posteriori, para recordar también los caballos predilectos de parada, caza o paseo.

Otras inscripciones que debemos mencionar son las situadas sobre los cuerpos de algunos de los caballos de las camas que nos ocupan. Cinco de los caballos representados en las imágenes figuradas de Hispania ( $n^{\circ} 47$ a $53,73,75$ y 76 ) llevan inscripciones en el anca o en la espalda: los de las $n^{\circ} 47$ (ya comentado en este apartado y que no volveremos sobre él), $53,73,75$ y 76 . Es muy habitual en la documentación arqueológica de la antigüedad tardía, en las imágenes equinas, tanto de circo como de caza, leer en las ancas y/o en las espaldas de los caballos ${ }^{170}$ unas marcas, letras (sólo las iniciales o palabras enteras normalmente en genitivo) o signos, correspondientes a los hierros de las cuadras o propietarios ${ }^{17}$. Sobre los caballos afrontados de la cama $n^{\circ} 53$ se observan con dificultad restos de inscripción, seguramente signos - una hedera o un símbolo similar al que lleva el caballo Perseus de una placa de marfil ${ }^{172}$ - como podriamos intuir en el caballo de la derecha. La hedera aparece también en el anca de los équidos de las camas $\mathrm{n}^{\circ} 75$ y 76 . En la espalda de estos dos últimos caballos debemos entender, que también llevaban un circulo, como se puede ver aún, muy claramente, en el $n^{\circ} 76$. La lectura de los restos de inscripción que pueden entreverse en el anca del caballo con jinete de la cama del Metropolitan Museum ( $n^{\circ} 73$ ) (fig. 26), observamos tres letras CLD (la última podria corresponder, aunque dudosamente, a una $\mathrm{V}$, la parte superior no es visible) en una línea superior y, justo debajo de la $L$, se destaca claramente un círculo (no creemos que se trate de una $O$ ya que debería ser más alargada y estrecha para coincidir con el tamaño de las otras N). Hay múltiples ejemplos comparables a estas marcas en los mosaicos del Norte de África o de Hispania. Mencionemos sólo, a título representativo, el mosaico de los caballos del Antiquarium de Carthago, y los circences de Mérida y Barcino ${ }^{173}$.

Podemos constatar como las camas con inscripción calada o incisa, vistas hasta ahora, se enmarcan dentro de tres campos diferentes. Por un lado, aquellas que son de tipo aclamatorio, como la pieza de Almazarrón $\left(n^{\circ} 43\right)$ y la de Pedrosa de la Vega $\left(n^{\circ} 45\right)$, con el paralelo de gran similitud procedente de Tamuda en la Mauritania Tingitana. En las tres piezas el sentido aclamatorio de uiuas es claro, y

io KLUMBACH, "Pferde mit Brandmarken", op.cit., p. 7, fig. 7. 1. Franz Joseph DoLGER, «Profane und religiöse Brandmarkung der Tiere in der heidnischen und christlichen Antike", Antike und Christentum, vol. III, Kultur- und religions geschichtliche Studien, Münster 1932 (1975), p. 25-61, 8 lám.

i71 DARDER, "El mosaic circenc de Barcino ...", op. cit.

172 AlFoldo y Alfoldi, Die Kontorniat-Medaillons, op. cit. lám. 271.3. M-Ch. HelLmann, "Tessere", en Ch. Landes (ed.), Le cirque et les courses de chars. Rome-Byzance, Lattes, 1990, p. 303 y 309 , fig. 62

173 J.W. SAlomonSON, La mosaique aux chevaux de antiquarium de Carthage, La Haya, 1965, entre otras p. 58. Alvarez Martinez, Mosaicos romanos .... op. cit., nº 14, lám. 39 a 44. Darder, "El mosaic circenc de Barcino ...", op. cit. 


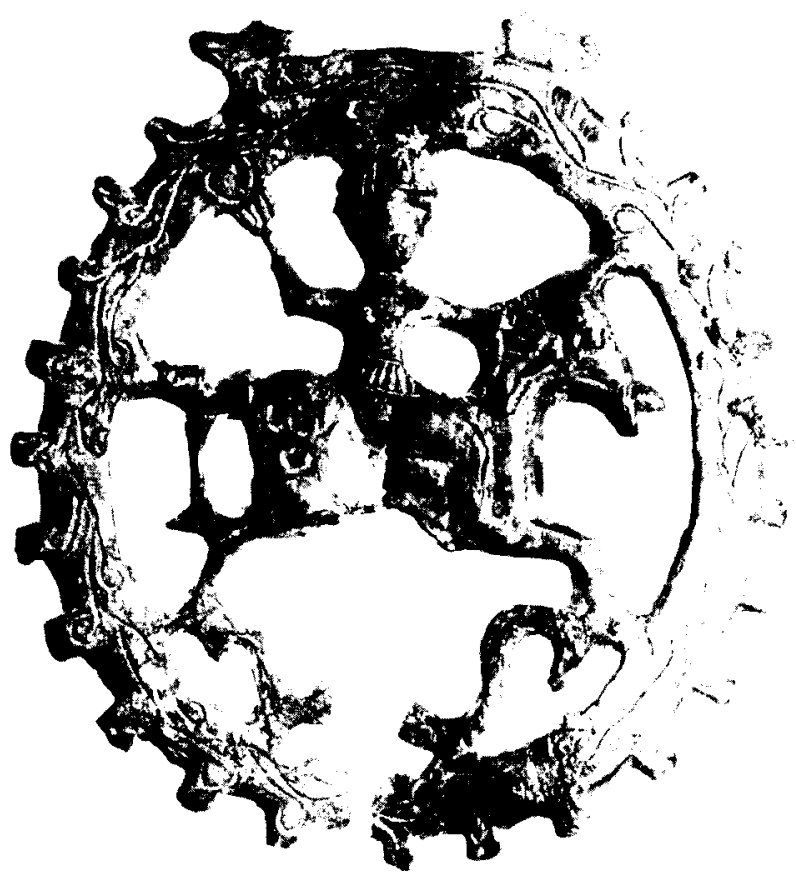

Fig. 26. Cama de procedencia desconocida, $n^{\circ} 73$, conservada en el Metropolitan Museum de Nueva York (foto del Museo).

hace referencia al propietario, a excepción de la de Almazarrón que recuerda a Paulino. Las dos camas ( $n^{\circ} 44$ y 46 ) con la inscripción ex officina fórmula que en otros ejemplos se encuentra seguida por utere felix, hicieron creer por este motivo a P. de Palol que deberían ir acompañadas por otra cama, al otro lado del freno, donde se leería esta segunda parte ${ }^{174}$. Esto no ha podido ser demostrado, pues no existe ninguna de las camas donde aparezca ex officina que haya sido hallada con su gemela y tampoco ninguna donde se lea utere felix. Quizás, lo más verosímil sería pensar que en la otra cama aparecería el nombre del taller como sigue en el ejemplo de Mérida, ex officina $\mathrm{Neclec}<1>t i$, o alguna otra aportación difícil de aventurar si no encontramos las camas de un mismo freno asociadas. Este tipo de fórmula, sobre un objeto así, nos indica la importancia que tenian los talleres broncistas de esta época. Ésta era tal que el nombre del taller artesano 
podia llegar a estar marcado en la superficie ornamental más importante de una pieza.

Por último, las camas de Clunia $\left(n^{\circ} 47\right)$ y de la colección Jules Sambon de París $\left(n^{\circ} 48\right)$ con las inscripciones E $\lambda u_{\chi}$ y Tagus respectivamente hacen referencia directa al caballo representado e indirectamente a la funcionalidad de la pieza como parte de un freno de caballo. Las marcas en las ancas y en las espaldas nos transmiten una realidad equestre típica de la Península lbérica confirmada ya en numerosos documentos arqueológicos.

Podemos decir que con respecto a la cantidad de camas de freno encontradas hasta el momento (cerca de 80 ), son pocas las inscripciones que se leen en ellas. No obstante, según nuestro parecer, creemos que son suficientes y de vital importancia tanto como reflejo y esclarecimiento del contexto donde se movían estos objetos como para poder determinar de forma cada vez más precisa el papel que estas camas, y su decoración tan alusiva, desempeñaban en la Hispania de la antigüedad tardía.

\section{INTERPRETACIÓN DE LAS CAMAS CON DECORACIÓN ANIMAL}

Hemos visto que existen varios tipos de camas con decoración animal, donde aparecen frecuentemente caballos, panteras y excpecionalmente osos y delfines, a la vez que animales hibridos.

Las piezas con representación de un único caballo enjaezado o no $\left(n^{\circ} 47\right.$ a 52 , incluyen aquellas con inscripción) vienen a corroborar todo lo dicho sobre la importancia del caballo y la cría caballar en la Hispania de la antigüedad tardía, al igual que lo confirman las piezas con la representación de un caballo montado $\left(\mathrm{n}^{\circ}\right.$ 73 a 76) que estudiaremos más adelante. No podemos afirmar categóricamente, tal como hemos avanzado, cuáles son los caballos que podrian ser considerados como de carreras o aquellos que son de parada, pues los atributos no son io suficientemente definitorios, a excepción de la pieza de Monturque ( $\left.n^{\circ} 51\right)$. En esta última cama el caballo aparece ensillado - se trata de una sella equestris típicamente romana- y, como hemos dicho, la figura animal y la parte circular de la cama proceden de fundiciones diferentes, habiendo sido soldadas con posterioridad; por ello, podriamos pensar que el caballo era montado por un jinete hoy perdido.

Anteriormente nos hemos referido al símbolo agonístico de la victoria en las camas $n^{\circ} 47$ y 48 ; éste también lo podemos observar en la procedente de Clunia $\left(n^{\circ} 52\right)$ y en las del Metropolitan Museum $\left(n^{\circ} 73\right)$ y El Coronil $\left(n^{\circ} 72\right)$. En la primera de ellas, el enganche de montante se halla remarcado por varias hojas de palma, pero no se puede afirmar con seguridad que efectivamente nos encontremos ante un simbolo asi; es muy aventurado, aunque no deja de ser tentador, ver en algunas 
de estas representaciones equestres a los equi circenses tan laudados por los documentos aqueológicos así como por la literatura.

Encontramos en la cama $n^{\circ} 53$, por primera vez con gran evidencia, la iconografía típica usada para recordar los caballos vencedores. Los dos caballos afrontados ante lo que parece una pequeña palmera recuerda los medallones del mosaico de Sorothus de Susa ${ }^{175}$ donde aparece, además el nombre de cada uno de los caballos. Asi mismo encontramos este motivo en un documento más tardío, pero de composición un poco distinta por el movimiento vertical de una de las cabezas de uno de los équidos, en un mango de lucerna de bronce hallado en Roma ${ }^{176}$.

Otros elementos de los arneses conectan perfectamente con el estilo de las camas y demuestran como el repertorio iconográfico es el normal de la época romana clásica, que prosigue - con la correspondiente evolución- en los talleres de la antigüedad tardía. En primer lugar, debemos citar unos distribuidores de correas hallados en la provincia de Palencia ${ }^{177}$. Estos elementos pueden distribuir cuatro o cinco correas y son de tipo rectangular. Los orificios para introducir las correas pueden ser circulares o rectangulares. El centro de la pieza está ocupado siempre por un caballo enjaezado o no, visto de perfil marchando hacia la derecha. Una de estas piezas, la conservada en el Musée des Antiquités Nationales de Paris, hallada en Cerrato (Palencia), es de una calidad extraordinaria - como la de forma cuadrada que posee la Ariadne Galleries-y puede ser traídas a colación como el paralelismo más cercano de estas camas de freno ${ }^{178}$. Incluso la decoración geométrica de los perfiles externos es exactamente igual a la cama de la colección del RGZM ( $\left.n^{\circ} 41\right)$. Esta pieza de Cerrato tiene también una decoración espiguiforme en el vástago que parte del lomo del caballo, que podría ser puesta en relación - aunque con muchas reservas- con la simbología de la victoria. En la pieza procedente de El Coronil ( $\left.n^{\circ} 72\right)$, el anillo externo está también decorado con este tipo de motivo en espiga, y en la del Metropolitan ( $n^{\circ}$ 73) aparece un motivo vegetal. Veremos más adelante que la representación realizada es la de un jinete cazando; por tanto, no tiene nada que ver con la simbología de la victoria. Desgraciadamente, también este grupo de piezas se halla descontextualizado arqueológicamente y ninguna cronologia ni relativa ni absoluta puede ser apuntada.

CIL VIII, 22917.

DOLGER, "Profane und religiöse Brandrnarkung ...", op. cit., lám. 3.

77 PALOL 1967, p. 236-240, lám. IV-V. La nueva pieza de procedencia desconocida fue publicada en: DemiRJan (ed.), Treasures of the Dark Ages in Europe, op. cit., p. 136.

178 Agradecemos a Françoise Vallet, Conservadora del Musée des Antiquités Nationales de Saint Germain-en-Laye, el habernos proporcionado la documentación necesaria relativa a este objeto. Preparamos su publicacion para el boletín de dicho museo: Antiquités Nationales. 
Los otros elementos que son interesantes de comparar con las camas que nos ocupan son los pasarriendas que llevan en la parte superior la representación de un caballo de aspecto muy similar a los representados en las camas de Santa Elena (Jaén) ( ${ }^{\circ} 49$ y 50). Se trata del pasarriendas con caballo enjaezado de Morón de la Frontera (Sevilla) ${ }^{179}$, el de Burguillos de Cerrato (Badajoz), uno en el Museo Arqueológico Nacional de Madrid y, por último, el pasarriendas de la antigua colección Bouza (Madrid) sin lugar de procedencia ${ }^{180}$. El pasarriendas de Morón de la Frontera es habitualmente fechado hacia el año 200 d.C. Sin embargo, el conservado en el Museo Arqueológico Nacional lleva en la peana la inscripción uiua y el crismón, lo que lo sitúa cronológicamente con una cierta posterioridad, como ya hemos visto al tratar las fórmulas aclamatorias. Para los otros elementos citados, las fechas son inciertas y siguen oscilando entre los siglos II y IV d.C., con una raiz romana clásica evidente.

El material apuntado, junto a las camas estudiadas, nos dan una visión del mundo caballar de tipo muy homogéneo. Tanto los pasarriendas como los distribuidores de correas, las phalerae y las camas de frenos se hallan situados en un horizonte iconográfico lleno de semejanzas.

Un problema diferente es el que plantean las piezas $n^{\circ} 54$ a 57 . La parte superior del animal está compuesta por cabezas o prótomos de caballos afrontados y vueltos. El resto del cuerpo es un delfín. En la pieza $n^{\circ} 54$, de procedencia desconocida, los atributos de los delfines son mucho más aparentes que en la de Cástulo (Jaén) ( $n^{\circ} 55$ ), al igual que lo son en las camas de la Ariadne Galleries. En la amplia serie de hallazgos procedentes de la Mauritania Tingitana, existe uno particularmente interesante por su carácter homogéneo con la serie hispánica, que es el de Volubilis ${ }^{181}$ (fig. 27). En esta cama, los prótomos de caballos y delfines están perfectamente señalados y su morfologia y factura es igual a los mencionados de Hispania. Cabe pensar por tanto en unos muy factibles y estrechos contactos comerciales a ambos lados del Estrecho de Gibraltar, tal como se sabe para otros productos de la antigüedad tardia. La otra cama a la que debemos hacer referencia, es la de Pedrosa de la Vega ( $n^{\circ} 58$ ), aunque no presenta ningún problema de interpretación, pues queda claro que los dos animales representados son delfines sin interferencias de caballos.

Algunos autores han visto en estos objetos una simbología cristológica de salvación y asociación conjunta de caballo y delfín como animales con un carácter funerario ${ }^{182}$; cuestión en la que no entramos ya que nos parece fuera de lugar. Lo

1/9 A. BLANCO, "El pasarriendas romano de Morón», Archivo Español de Arqueologia, 40, 1967, p. 99-103, 7 fig.

180 A. GarCia y BeLLIDO, "Nuevas piezas pertenecientes a atalaje de carros romanos hallados en España", Archivo Español de Arqueologia, XXIX, 1956, p. 206-211, 15 fig. A. Fernandez de AvILES, "Pujavantes romanos esculturados. Contribución al estudio de la hipiatria antigua", Archivo Español de Arqueologia, XXXVII, 1964, p. 3-21, 9 fig.

$181 \mathrm{Ch}$. Boube Piccot, "Une phalère de mors à decot animalier du Musée de Lectoure (Gers)", Pallas, "Mélanges offerts á Monsieur Michel Labrousse ". 1986, p. 387-392, lám. 3.4

182 MARCOS POUS y VICENT, "Dos camas de freno de caballo...", op. cit., p. 40-45. 


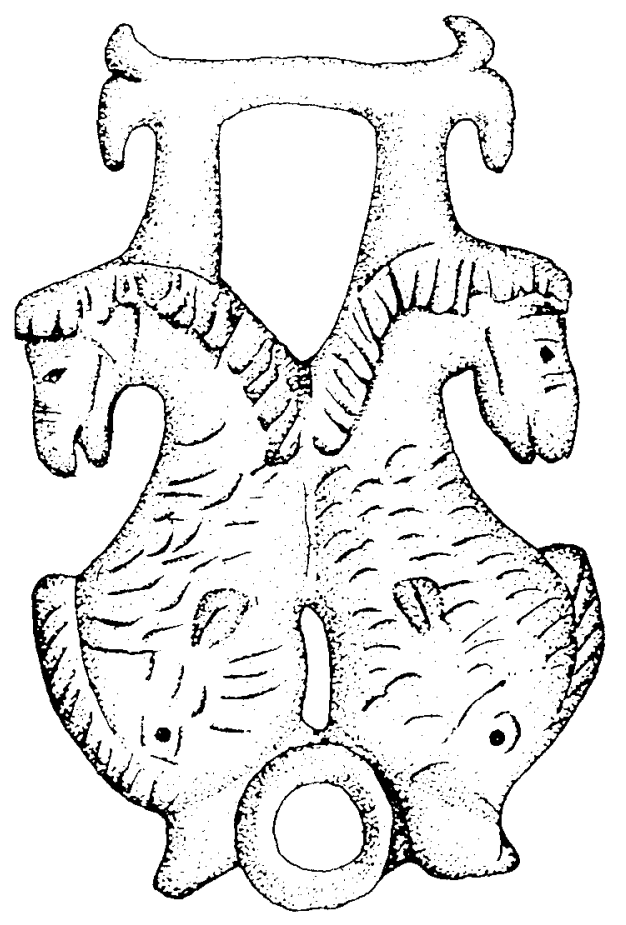

Fig. 27. Cama procedente de Volubilis (según Ch. Boube-Piccot, 1986).

que si es cierto es que en muchos casos el enganche de montante de estas camas -tanto geométricas como figuradas- muestran representaciones de delfines, hecho que también es frecuente en los pequeños objetos de bronce de época romana. ¿Tiene el delfin, en estos casos, una simbologia precisa? ¿Es ésta de tipo de salvación, de tipo mitológico, funerario, etcétera? No creemos que se deba forzar tanto la interpretación, ¿podriamos pensar en la comparación dada por la velocidad de unos animales terrestres con otros acuáticos? Estas representaciones de delfines, a excepción de la cama de Conímbriga $\left(n^{\circ} 67\right)$ con un hibrido -león/delfín (?) - no vuelven a aparecer en ningún otro elemento de atalaje de caballos o adornos de carros. También es singular la forma de situar los caballos afrontados y con la cabeza vuelta, hecho que se repite en toda la serie de representaciones de felinos. Decimos singular, no por no habitual, sino por tratarse de piezas con una funcionalidad precisa, pues la temática de animales afrontados es conocida desde la más remota antigüedad en todas las regiones, incluso de la cuenca mediterránea occidental y de la actual Europa central. Por tanto no consideramos necesario dete- 
nerse en este problema, pues sabemos de la antigua iconografía heráldica oriental, de su paso a la iconografía de época cristiana y de su habitual aparición en los sistemas iconográficos equinos, situándose los caballos afrontados a una palmera o a los modii (cilindros de premio) ${ }^{183}$, como es frecuente en los ejemplos musivos ya aludidos al principio de éstas páginas.

El mismo esquema distributivo de animales afrontados con la cabeza vuelta se repite en las camas con representaciones de panteras ( $n^{\circ} 59$ a 64) (fig. 28). Una pieza muy semejante a las camas que nos ocupan fue hallada en Lectoure (Gers, Francia). Esta cama, con decoración de panteras, posee el paso de filete taponado por las concreciones férreas y un enganche de montante triangular. Por tanto su funcionalidad es clara, aunque su cronología no ha sido apuntada ${ }^{184}$. Es patente el paralelismo iconográfico con las camas aquí estudiadas y muestra la existencia de un comercio de este tipo de materiales, al igual que ocurre con la cama hallada en Volubilis que hemos traido a colación precedentemente.

En lo que a los animales representados en las camas se refiere, éstos son de origen oriental, pero su mercado era amplio en la cuenca mediterránea y se podria decir que habitual en el Norte de África; por ello no debe sorprender su aparición en Hispania. El comercio de animales exóticos era un hecho frecuente ${ }^{185}$, y si por un lado dudamos de la existencia numerosa de panteras en la Península Ibérica, por otro creemos que es muy factible que fuese un tema decorativo o iconográfico conocido por los artesanos de los talleres de producción de estas piezas. Siempre se ha querido ver un carácter extremadamente oriental en las representaciones de estas camas con panteras ${ }^{186}$. Sin embargo, creemos que entran bien dentro del repertorio animalístico conocido en los siglos IV al VI d.C., y por ello su aparición en objetos hispánicos no debe sorprender, y menos en piezas formando parte de los arreos de caballos, pues son conocidos al menos dos pasarriendas con motivos de panteras ${ }^{187}$, uno conservado en el Museo de Mérida y otro en el MAN. El de Mérida presenta una pantera que apoya sus patas en cabezas de cisne. El otro ejemplar, el de Madrid, se halla ornamentado con dos cabezas de felinos - probablemente panteras - y es de una técnica un poco diferente. Los dos pasarriendas

183 Noël DuVAL, "L'introduction des couronnes métalliques et des 'cylindres de prix' en Occident d'aprés l'Histoire Auguste", Historiae Augustae Colloqium, MCMXC. Macerata, 1991, p. 171- 182, 6 fig. Id., "Recherches nouvelles sur les prix de concours représentés sur les mosaïques", Bulletin Archeologique du Comite des Travaux Historiques et Scientifiques, 22, 1987-1989 (1992), p. 177-209, 28 fig.

18: Ch. BOUEE PICCOT, "Une phalere de mors a decor animalier du Musée de Lectoure (Gers)", op. cit. p. 387-392, 3 lám.

185 F. BERTRANoY, "Remarques sur le commerce des bètes sauvages eritre l'Afrique du Nord et I'Italie (lle siècle avant J.-C. - IVe siècle après J.-C.)", MEFRA. 99, 1987, p. 211-241.

136 PALOL 1953-54, p. 289-292.

iki M. Molina y G. Mora, "Una nueva teoría sobre fos llamados 'pasarriendas': en tomo a una pieza de carro del Museo de Mérida", Archivo Español de Arqueologia, 55, 1982, p. 205-210, 4 fig. 


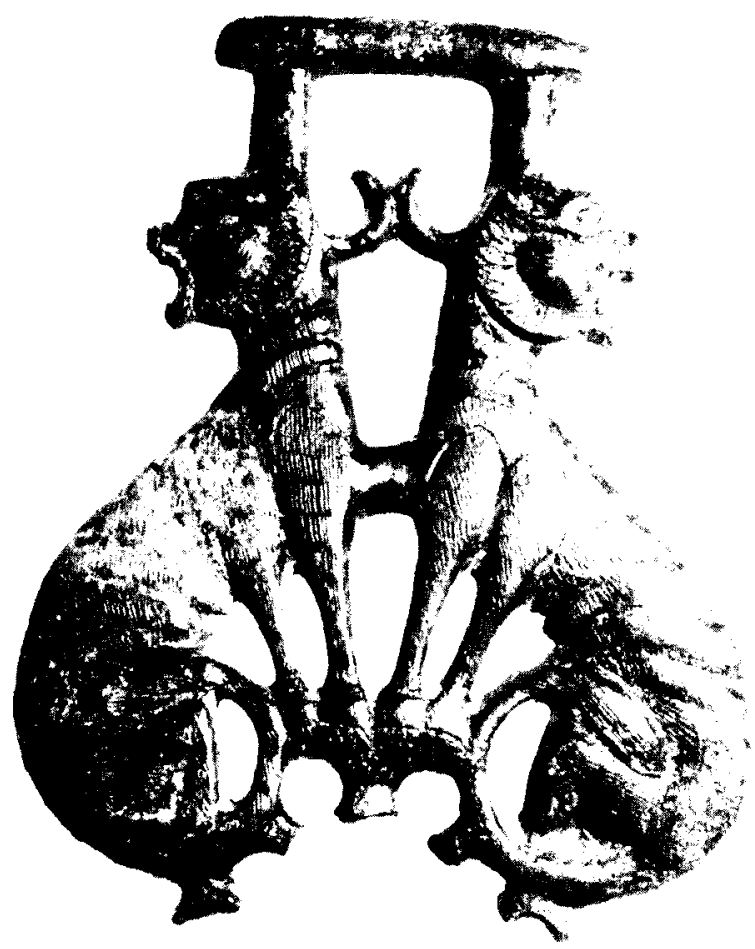

Fig. 28. Cama de procedencia desconocida, $n^{\circ} 62$, conservada en el Metropolitan Museum de Nueva York (foto del Museo).

han sido fechados entre los siglos III y IV d.C. ${ }^{188}$, cronologia muy similar al pasarriendas con la figura de un équido de Morón de la Frontera, antes citado.

No creemos que debamos remontarnos a piezas de la Grecia arcaica o de la cultura escito-sármata ${ }^{189}$, para buscar el origen de las representaciones de animales afrontados con la cabeza vuelta pues, como decíamos, estas figuras son habituales en los repertorios iconográficos romanos. También lo son las representaciones de delfines y de osos, estos últimos, por ejemplo, en la Península Ibérica, pues sabemos gracias a Claudio Claudiano ${ }^{190}$ que la ninfa Terón cazaba osos en Hispania. También en el Norte de África, los pavimentos musivos tardios - sobre

188 Molina y MORA, "Una nueva teoria...", op.cit., p. 209.

189 PALOL 1953-54, p. 289-292.

190. Claudio Claudiano, Carmina, De consulatu Stilichonis liber tertius, 309-311. 
todo aquellos de uenationes - son un contínuo recordatorio de estos temas. La lucha de osos en el anfiteatro corresponde a una temática frecuente en la iconografía romana , asi por ejemplo la podemos observar en el díptico Barberini, procedente del taller de Constantinopla y fechado en la época de Petronio Máximo, ca. 433 d.C. ${ }^{191}$, y otros trabajos en marfil, como son el díptico del Louvre de hacia el año 400 d.C., el de City Museum de Liverpool de principios del siglo V d.C. y el del Ermitage de San Petersburgo fechado hacia los siglos V o VI d.C. ${ }^{192}$.

Cuando nos referiamos a las represetaciones de caballos, hemos visto que existen algunos casos en que éstos se hallan combinados con cuerpos de delfines. Lo mismo ocurre con las representaciones de panteras. En una cama procedente de Conimbriga ( $n^{\circ} 67$ ) aparecen dos cabezas o prótomos de felinos -panteras 0 leones-con colas en tridente, que muy probablemente hacen referencia a un animal o monstruo marino. Esta pieza se escapa un poco del conjunto perfectamente homogéneo; pero no por ello deben ser excluídas y su cronología variada, a pesar de no conocerse su nivel estratigráfico originario.

Dentro de los grupos de camas con decoración zoomorfa, pero con imágenes narrativas y escenas de distinto tipo, hallamos aquellas con la representación de un équido montado por un jinete que levanta las manos. Éstas responden a la del Metropolitan $\left(n^{\circ} 73\right)$ y las dos pertenecientes a la Ariadne Galleries ( $n^{\circ} 75$ y 76) que ya hemos comentado en el apartado de la interpretación epigráfica. La pieza de Cártama (Málaga) ( $n^{\circ} 74$ ) (fig. 29) exhibe la misma escena, pero está fracturada por la parte inferior, hecho que podría hacer pensar en que falta la imagen de un animal, tal como encontramos en la escena de caceria de la cama de El Coronil ( $n^{\circ} 72$ ), aunque creemos que responde a una imagen simple de jinete y caballo. Estas dos piezas llevan en el enganche de montante imágenes de delfines esquematizados.

Ya hemos dicho que es difícil precisar el tipo de animal que aparece en la cama de El Coronil, quizás una cierva o un jabalí, animales habituales en los temas de caza. Existe una pieza sin procedencia en el Museo Lázaro Galdiano (Madrid), semejante a las camas, pero sin enganche de montante ni perforación ${ }^{193}$. Ésta, que debemos incluirla en el mismo tipo de iconografía pero no de funcionalidad, ostenta la representación de un jinete cazando una cierva. El paralelismo musivo más cercano a esta representación es el medallón central del pavimento llamado de Dulcitius de la villa romana de El Ramalete (Tudela, Pamplona) ${ }^{194}$. En él, el caballo enjaezado ataca una cierva ya herida por el jinete,

191 W.F. VOLBACH, Elfenarbeiten der Spätantike und des frühen Mittelalters, Maguncia, 1976, p. 36, lám. 12, n. 48.

192 VoLBACM, Elfenarbeiten der Spätantike..., op.cit. p. 26 y 41 , lám. 3, 17, 19 y $61, n .12,59$ y 60.

193 PALOL 1989 , p. 46 y 48 , fig. 10.

194 TaRacena, VÁzouez de Parga y MezoujiRIZ, Excavaciones en Navarra..., op. cit.., lám. X-XII. 


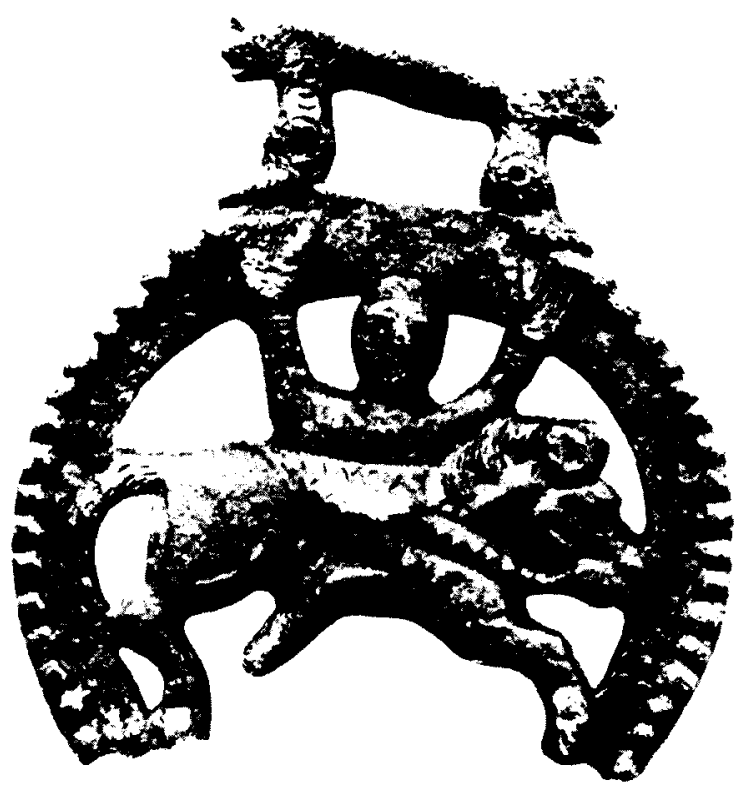

Fig. 29. Cama procedente de Cártama $\left(n^{\circ} 74\right)$.

quien, al igual que en la cama, tiene su brazo derecho levantado. Esta misma escena se repite en uno de los cuadros pictóricos de una casa romana de Mérida, fechada en el siglo IV d.C.. En ésta, también el jinete alza el brazo y la cierva tiene la lanza clavada.

La pieza del Metropolitan ( $n^{\circ} 73$ ) y las de la Ariadne Galieries ( $n^{\circ} 75$ y 76 ) no corresponden a escenas de caza, ya que no aparece ningún venado debajo del caballo. La cuestión que se plantea ante estas tres camas es la interpretación de la parte inferior del registro central de la pieza. Unido a las patas del caballo y a la perforación del paso de filete ( $y$ al anillo externo de la pieza) aparecen dos formas alargadas y ondulantes (como una "S" estirada) que permite pensar en la esquematización de dos serpientes. Éstas pueden responder o bien a un recurso técnico resuelto con gran habilidad estilística o bien a que nos encontremos ante una imagen mitológica a determinar (este aspecto queda abierto).

Todas estas escenas se hallan muy cerca iconográficamente de las placas de "monedero" de época merovingia es decir de los siglos VI y VII d.C.. En ellas es habitual encontrar la representación de un jinete (caballero) con una lanza. Aunque 
creemos que más bien se trata de guerreros a caballo y no de propietarios cazando ${ }^{195}$, sí es cierto que existen algunos de estos jinetes con las manos alzadas como en las camas hispanas ${ }^{196}$. Aquellas se interpretan con una simbología religioso-iconográfica que nos parece fuera de lugar aplicarlas a las camas que nos ocupan, pues sus connotaciones romano-mediterráneas son evidentes en relación al mundo de los caballos y de los propietarios.

Estas escenas de caceria nos introducen en la imagen de uenatio que aparecen en las camas de Burgos (?) $\left(n^{\circ} 70\right)$ y de Sevilla $(?)\left(n^{\circ} 71\right)$. En ellas aparecen prácticamente todos los animales mencionados hasta ahora: el jabali, el oso, el ciervo y un perro. Según $\mathrm{P}$. de Palol ${ }^{197}$ las dos piezas proceden del mismo taller e incluso del mismo molde, siendo retocadas posteriormente, ya que los aros exteriores y las asas del enganche de montante son diferentes. Es muy posible que asi sea, y si no lo fuese, lo que si es cierto es que las dos piezas surgen del mismo modelo. Su difusión dentro del mercado seguiría las pautas comerciales de estos objetos, respondiendo siempre a las demandas de la clientela extendida por todos los puntos geográficos peninsulares e incluso más allá de estos territorios, tal como hemos visto con las piezas de Lectoure y las de Mauritania Tingitana, especialemente las de Volubilis y Tamuda.

Los animales representados son los clásicos de las uenationes, tanto en pinturas como en mosaicos y en sarcófagos o en pequeños objetos. Asi podemos aportar un ejemplo de gran calidad, como son las phalerae de plata de Ittenheim (BajoRhin, Alemania), publicadas en su día por J. Werner ${ }^{198}$, que aunque de cronología más tardia - del siglo VII d.C.- muestran con absoluta claridad la perduración de los temas iconográficos en determinadas piezas. La relación existente entre estos elementos de arnés de caballo con escenas de caza permite suponer que nos encontramos ante un material cuya funcionalidad está claramente destinada a la del enjaezamiento de los caballos de parada o de caza; en ellos las representaciones que figuran celebran o auguran los hechos acontecidos o por acontecer. Se trata en realidad de temas completamente banales, a pesar de ser numéricamente más escasos, en el número de camas conocidas, que los temas geométricos. No insistiremos más en el tema de la uenatio pues si apuntamos aquí todos los paralelismos pictóricos y musivos que existen, sería una serie muy larga y, por otra parte, bastante conocida. Quizás merece la pena anotar dos nuevos hallazgos, todavía no publicados en su totalidad, y donde aparecen pavimentos musivos con temas referidos a la caza del jabali. Se trata de la uilla de las Tiendas en Mérida y la

195 D. RENNER, Die Durchbrochenen Zierscheiben der Merowingerzeit, Maguncia, 1970.

196 RENNER, Die Durchbrochenen Zierscheiben..., op.cit., n. 613-630.

197 PALOL 1989, p. 50-52.

198 J. WERNER, Der Fund von Ittenheim. Ein alamannisches Fürstengrab des 7. Jahrhunderts im Elsass, Estrasburgo, 1943. 
extraordinaria uilla de Materno en Carranque (Toledo), fechables ambas en el siglo IV d.C. con un período de utilización todavía no determinado ${ }^{199}$.

En último lugar, quedan por analizar aunque sólo sea someramente, las dos camas de procedencia desconocida $\left(n^{\circ} 77\right.$ y 78$)$ con la representación de un hombre luchando con un león, que ha sido siempre interpretado como uno de los doce trabajos de Hércules: el de la lucha con el león de Nemea. Este episodio se refiere a Hércules cuando se enfrenta al león y tras las flechas que le lanza no obtiene resultados, decide enfrentarse a él con una maza y ahogarlo después ${ }^{200}$. Según la imagen representada en este par de camas, creemos que se trata de este momento preciso del enfrentamiento. Nos encontramos ante un antiguo tema iconográfico greco-romano repetido frecuentemente tanto en la literatura como en el arte. Éste permite de nuevo conectar las camas de freno de caballo de la antigüedad tardia hispana con el puro clasicismo romano de la primera época.

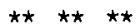

El estudio de las piezas que hemos abordado representa una parte del complejo mundo de las guarniciones de caballos, y por tanto del mundo de la equitación, ya sea de tipo competitivo, como las carreras de carros del circo, ya sea de tipo contemplativo, como el paseo a caballo o la caza.

Gracias a estos materiales vemos como durante la antigüedad tardia hispánica existió una consideración - tantas veces repetida- de innovación conjugada con la continuidad. Ésta última queda bien patente especialmente en las camas que hemos estudiado en el presente trabajo, que con los temas iconográficos en ellas expuestos y con su propia funcionalidad permiten retrotraer lo que fue el interés de los individuos por el mundo del caballo. A pesar de las transformaciones acaecidas con el cristianismo, quedaron perpetuadas determinadas formas y modos de vida y de ocupación, intrínsecos en la sociedad, que difícilmente podian ser olvidados. Tanto el material arqueológico citado, como las fuentes literarias de época tardía demuestran que el caballo y todo lo que él implica son hechos suficientemente sólidos como para poder afirmar que las costumbres a este respecto tuvieron una perduración temporal mucho más amplia de lo que se habia supuesto hasta ahora. El caballo, profundamente ligado a la cultura hispánica, es explotado, vendido,

199 D. Fernández Galiano, "La villa romana de Materno", Mosaicos romanos (in memoriam M. Femández Galiano), Madrid, 1989, p. 255-269. Blanco Freiseiro, Mosaicos romanos de Mérida..., op.cit, p. 42-59, lám. 105-108.

200 P. GRIMAL, Dictionnaire de la mythologie grecque et romaine, Paris, 1951, edición española, Diccionario de la mitologia griega y romana, Barcelona-Buenos Aires, 1982, p. 243, s.v. Heracles. 
Frena equorum. Guamiciones de frenos de caballos en la antigüedad tardia hispánica

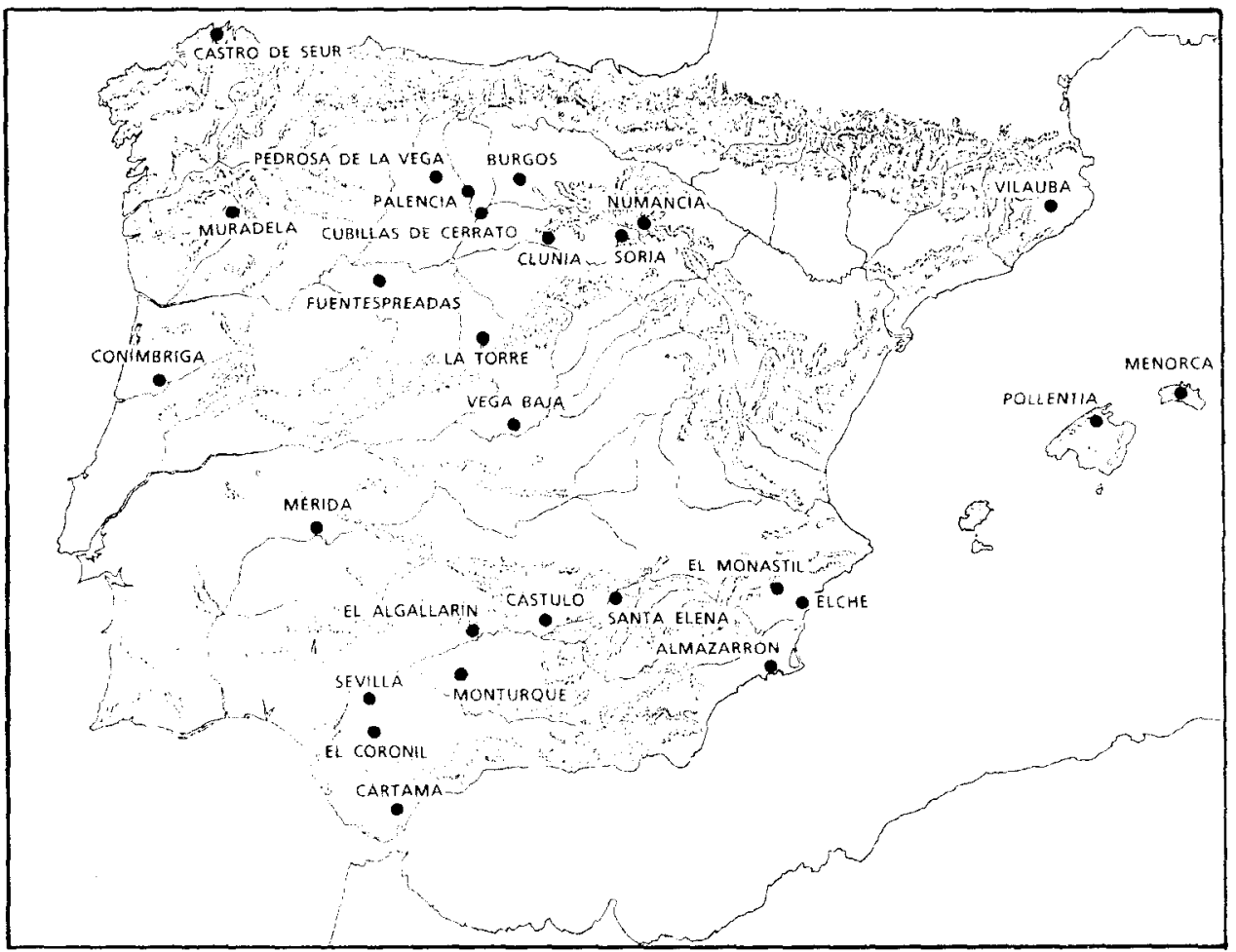

Fig. 30. Mapa de distribución de los yacimientos donde aparecen las camas estudiadas (indicamos el lugar de hallazgo y el número de inventario, no se reflejan las 25 piezas de procedencia desconocida): Conimbriga, 1 a 3, 19, 65, 67 a 69; Vega Baja, 4-5; Clunia, 6-7, 47 y 52; Fuentespreadas, 8 a 11; Numancia, 13 a 15; Castro de Seur, 16; El Algallarín, 18; Menorca, 22; provincia de Sevilla, 23, 41 y 71; Vilauba, 24; Cubillas de Cerrato, 25-26; provincia de Palencia, 27-28; Pollentia, 29 a 32; provincia de Soria, 36; Muradela, 39; EI Monastil, 42; Almazarrón, 43; Pedrosa de la Vega, 45 y 58; Mérida, 46; Santa Elena, 49-50; Monturque, 51; Cástulo, 55; Elche, 59 y 61; La Torre, 63; Burgos, 70; El Coronil, 72; Cártama, 74.

aprovechado y ensalzado, es decir, es utilizado al máximo de sus posibilidades. Ello hizo que éste fuese en Hispania y fuera de ella un animal deseado.

\section{LISTADO DE LAS PIEZAS INVENTARIADAS}

En este listado se indica el número de inventario dado a las piezas para este trabajo, su lugar de hallazgo y de conservación. Asi mismo se anota el número de la figura.

1. Conímbriga, Portugal. Museo Monográfico de Conímbriga. Fig. 6. 
2. Conímbriga, Portugar. Museo Monográfico de Conímbriga. Fig. 6.

3. Conímbriga, Portugal. Museo Monográfico de Conímbriga. Fig. 6.

4. Vega Baja, Toldeo. Museo de Santa Cruz, Toledo. Fig. 3 y 6.

5. Vega Baja, Toledo. Museo de Santa Cruz, Toledo. Fig. 3 y 6.

6. Clunia, Burgos. Museo Arqueológico de Burgos. Fig. 7.

7. Clunia, Burgos. Museo Arqueológico de Burgos. Fig. 7.

8. Fuentespreadas, Zamora. Fig. 4 y 7.

9. Fuentespreadas, Zamora. Fig. 4 y 7.

10. Fuentespreadas, Zamora. Fig. 4 y 7.

11. Fuentespreadas, Zamora. Fig. 4 y 7.

12. Procedencia desconocida. Museo Episcopal de Vic, Gerona. Fig. 8.

13. Numancia, Soria. Museo Numantino. Fig. 8.

14. Numancia, Soria. Museo Numantino. Fig. 8.

15. Numancia, Soria. Museo Numantino. Fig. 8.

16. Cástro de Seur, Ortigueira, Galicia. Facultad de Filosofia y Letras de Santiago de Compostela (?). Fig. 8.

17. Procedencia desconocida. MAN. Fig. 9.

18. El Algallarin, Adamuz, Córdoba. Museo Arqueológico de Córdoba. Fig. 9.

19. Conimbriga, Portugal. Museo Monográfico de Conimbriga. Fig. 9.

20. Procedencia desconocida. IVDJ. Fig. 9.

21. Procedencia desconocida. MAB. Fig. 10.

22. Menorca. MAN (?). Fig. 10.

23. Provincia de Sevilla. RGZM. Fig. 10.

24. Vilauba, Camós, Gerona. Fig. 10.

25. Cubillas de Cerrato, Palencia. IVDJ. Fig. 10.

26. Cubillas de Cerrato, Palencia. IVDJ. Fig. 10.

27. Provincia de Palencia. Colección Fontaneda, Palencia. Fig. 3 y 11.

28. Provincia de Palencia. Colección Fontaneda, Palencia. No se dibuja. Fig. 3.

29. Pollentia, Mallorca. Museo de la Lonja, Palma de Mallorca. Fig. 11.

30. Pollentia, Mallorca. Museo de la Lonja, Palma de Mallorca. Fig. 11.

31. Pollentia, Mallorca. MAB. Fig. 11.

32. Pollentia, Mallorca. MAB. Fig. 11. 
33. Procedencia desconocida. Mueso Episcopal de Vic, Gerona. Fig. 12.

34. Procedencia desconocida. MAN. Fig. 12.

35. Procedencia desconocida. MAB. Fig. 12.

36. Provincia de Soria. Colección Monteverde, Burgos. Fig. 12.

37. Procedencia desconocida. MAN. Fig. 13.

38. Procedencia desconocida. IVDJ. Fig. 13.

39. Muradela, Mourazos, Orense. Museo Arqueológico de Orense. Fig. 13.

40. Procedencia desconocida. MAN. Fig. 13.

41. Provincia de Sevilla. RGZM. Fig. 14 y 23.

42. El Monastil, Elda, Alicante. Museo Arqeuológico de Elda. Fig. 14.

43. Almazarrón, Cartagena, Murcia. Perdida. No se dibuja.

44. Procedencia desconocida. Facultad de Filosofia y Letras de Santiago de Compostela (?). Fig. 14 y 24.

45. Pedrosa de la Vega, Palencia. Museo de Saldaña, Palencia. Fig. 14.

46. Mérida, Badajoz. MAN. Fig. 15.

47. Clunia (?), Burgos. IVDJ. Fig. 15

48. Procedencia desconocida. Colección Jules Sambon, Paris. Fig. 15.

49. Santa Elena, Jaén. Museo de Linares, Jaén. Fig. 16.

50. Santa Elena, Jaén. Instituto de Estudios Gienenses, Jaén. Fig. 16.

51. Monturque, Córdoba. Museo Arqueológico de Córdoba. Fig. 15.

52. Clunia, Burgos. Museo Arqueológico de Burgos. Fig. 16.

53. Procedencia desconocida. Ariadne Galleries, Nueva York. Fig. 16.

54. Procedencia desconocida. Museo Lázaro Galdiano, Madrid. Fig. 17.

55. Cástulo, Jaén. Fig. 17.

56. Procedencia desconocida. Ariadne Galleries, Nueva York. Fig. 17.

57. Procedencia desconocida. Ariadne Galleries, Nueva York. Fig. 17.

58. Pedrosa de la Vega, Saldaña, Palencia. Museo de Saldaña. Fig. 17.

59. Elche (?), Murcia. MAN. Fig. 18.

60. Procedencia desconocida. Museo Lázaro Galdiano, Madrid. Fig. 18.

61. Elche, Murcia. Walters Art Gallery, Baltimore. Fig. 18.

62. Procedencia desconocida. Metropolitan Museum, Nueva York. Fig. 18 y 28.

63. La Torre, Ávila. Museo Provincial de Ávila. Fig. 19. 
64. Procedencia desconocida. Museo Lázaro Galdiano, Madrid. Fig. 19.

65. Conímbriga, Portugal. Museo Monográfico de Conímbriga. Fig. 19.

66. Procedencia desconocida. MAB. Fig. 19.

67. Conímbriga, Portugal. Museo Monográfico de Conímbriga. Fig. 20.

68. Conimbriga, Portugal. Museo Monográfico de Conimbriga. Fig. 20.

69. Conímbriga, Portugal. Museo Monográfico de Conimbriga. Fig. 20.

70. Burgos (?). MAB. Fig. 20.

71. Sevilla (?). Museo Episcopal de Vic, Gerona. Fig. 21.

72. El Coronil (?), Sevilla. Museo Arqueológico de Sevilla. Fig. 21.

73. Procedencia desconocida. Metropolitan Museum, Nueva York. Fig. 21 y 26.

74. Cártama, Málaga. Museo Arqueológico de Málaga. Fig. 21 y 29.

75. Procedencia desconocida. Ariadne Galleries, Nueva York (?). Fig. 22.

76. Procedencia desconocida. Ariadne Galleries, Nueva York (?). Fig. 22.

77. Procedencia desconocida. Museo Lázaro Galdiano. Fig. 22.

78. Procedencia desconocida. Museo Lázaro Galdiano. Fig. 22. 